Portland State University

PDXScholar

\title{
What a saint am I! : The self-canonization of Madame Jeanne-Marie Guyon in the Quietist controversy of seventeenth-century France
}

Jennifer Marie Lior Blacke

Portland State University

Follow this and additional works at: https://pdxscholar.library.pdx.edu/open_access_etds

Part of the European History Commons

Let us know how access to this document benefits you.

\section{Recommended Citation}

Blacke, Jennifer Marie Lior, "What a saint am I! : The self-canonization of Madame Jeanne-Marie Guyon in the Quietist controversy of seventeenth-century France" (1998). Dissertations and Theses. Paper 5725. https://doi.org/10.15760/etd.7586

This Thesis is brought to you for free and open access. It has been accepted for inclusion in Dissertations and Theses by an authorized administrator of PDXScholar. Please contact us if we can make this document more accessible: pdxscholar@pdx.edu. 


\section{THESIS APPROVAL}

The abstract and thesis of Jennifer Marie Lior Blacke for the Master of Arts in

History were presented May 6, 1998, and accepted by the thesis committee and department.

COMMITTEE APPROVALS:

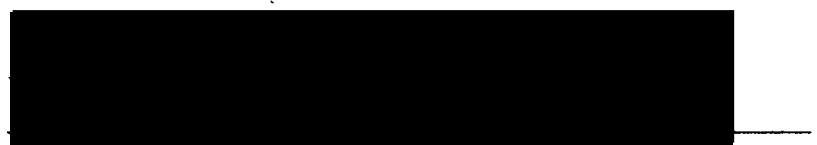

Thomas Luckett, Chair
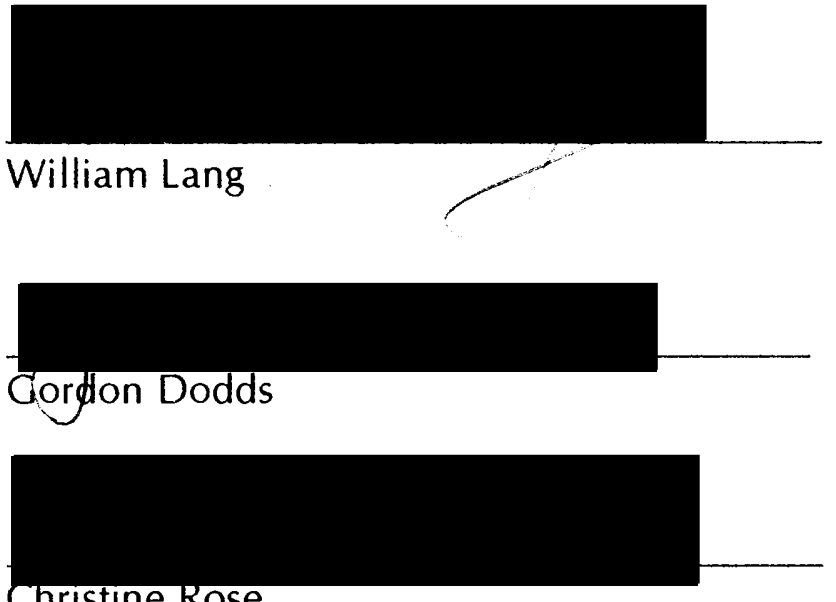

Christine Rose

Representative of the Office of

Graduate Studies 


\begin{abstract}
An abstract of the thesis of Jennifer Marie Lior Blacke for the Master of Arts in History presented May 6, 1998.
\end{abstract}

Title: What a Saint am I!: The Self-Canonization of Madame Jeanne-Marie Guyon in the Quietist Controversy of Seventeenth-Century France

At the center of the heated Quietist Controversy in late seventeenthcentury France was Jeanne-Marie Guyon, whose writings and teachings on inner prayer were similar to those of recognized Catholic mystics. Unlike celebrated mystics, however, Mme Guyon expounded a doctrine which seemed to concentrate not only on holy indifference, but on herself as the sole mechanism by which others could attain union with God. A careful reading of the writings of Mme Guyon reveals a woman obsessed with herself -- her salvation, her martyrdom, her popularity, and her superiority. Such a description corresponds perfectly with the suggestions of her foremost persecutor, the bishop of Meaux, Jacques-Bénigne Bossuet, that she saw herself as a living saint, above and beyond the mystics of the past, more powerful than the priests of the present, and positively ensured that she was the true bride of Christ who would rule beside him in the future.

In order to make sense of Mme Guyon's interpretation of herself, this thesis seeks to unite various aspects of her writings and personality, including 
the imagery of the Book of Revelation, sainthood, mysticism, sensuality in reference to Jesus, and persecution. Ultimately I suggest that her writings sought to prove her own assertion that she was the woman of the apocalypse, the highest level of saint in the Glorious Orders. Mme Guyon's autobiography appears to be a consciously constructed hagiography to serve in fortifying this image of herself. This self-canonization, compounded by the awkward imitation of accepted mystical doctrine, was central to Mme Guyon's condemnation in the French Quietist debates of the late seventeenth century. 
WHAT A SAINT AM I!:

THE SELF-CANONIZATION OF MADAME JEANNE-MARIE GUYON IN THE QUIETIST CONTROVERSY OF SEVENTEENTH-CENTURY FRANCE

by

JENNIFER. MARIE LIOR BLACKE

A thesis submitted in partial fulfillment of the requirements for the degree of

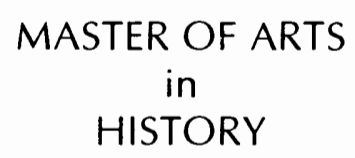

Portland State University 1998 
THIS THESIS IS DEDICATED TO

VICTORIA PLUM,

WHO TRULY WAS A LIVING SAINT. 


\section{ACKNOWLEDGEMENTS}

This master's thesis is the result of my first graduate class in French history, a seminar on the seventeenth century offered in Spring of 1996. I first found Mme Guyon's name as I was thumbing through the index of Pierre Goubert's Louis XIV and Twenty Million Frenchmen desperately looking for a term-paper topic. Her name lept out from the page, and even though I had no idea who she was, I was convinced that she would be the focus of a great paper. By the Fall I had resigned myself to the revelation that, like she had seduced so many at Louis XIV's court with her charismatic manner, I too had fallen victim to Jeanne Guyon's seductive personality. My thesis topic was settled.

This thesis and all of my graduate work at Portland State University was made possible by the generous support and encouragement of my advisor, Professor Thomas Luckett. There are not enough words in English or French to describe my gratitude to him. No matter how quiet, how shy, or how loud and outspoken I was, Professor Luckett was always patient and understanding. I feel so honored, and so lucky, to have been able to work with such an outstanding scholar and historian.

Professor Christine Rose of the PSU English department deserves mention for offering her fantastic seminar on Medieval Women's Literature in the Fall of 1997. Many of the ideas in this thesis are a direct result of readings and discussions from this class, as well as from the inspiring lectures given by Professor Rose. 
Thanks are also in order for Professor William Lang, who rescued my academic career by graciously agreeing to be my minor advisor. Despite his busy schedule, Professor Lang always found time to support me and my work..

Professor Gordon Dodds deserves credit for being a good sport by agreeing to be on my thesis committee. Who knew a colloquium could be so beneficial!

Last but not least, I would like to express eternal gratitude to my husband, William L. Blacke, who was always there with a warm cup of apple cider when I sat down to write, and who enlightened my bad mood with his brilliant and timely wit. (And who reminded me of Mme Guyon's four-somes when things got really bad!) I also thank my dear sister, Kristin Johnson, for her encouraging phone calls and letters, and my mother, Margaret Wagle, for her insights into Catholicism. Phthia Blacke, Francis and Margie Schuller, and the rest of my family and in-laws all deserve praise for their kind understanding when I was busy, and for their limitless support. Most of all, I extol Mme Jeanne Guyon, without whom this thesis would have been impossible - it has been an honor. 


\section{TABLE OF CONTENTS}

Introduction: Mme Guyon as Saint: The Path to Self-Sanctity Begins 1

Chapter 1: A Challenge to Sanctity: The "Quietist" Controversy ........... 17

Chapter 2: A Living Saint and the Queen of Heaven

Chapter 3: Mme Guyon as Saint: The Woman of the Apocalypse

Reveals Herself

Chapter 4: Mme Guyon as Saint: Constructing the Autobiography

Chapter 5: Mme Guyon as Saint: Autobiography as Hagiography

Conclusion: Mme Guyon and the Legacy of her Self-Constructed

Sanctity

Bibliography

Appendix A: Chapter 12 from the Book of Revelation 185

Appendix B: The Covenant of Consecration of Mme Guyon 


\title{
Introduction \\ Mme Guyon as Saint: The Path to Self-Sanctity Begins
}

\author{
My parents, particularly my father, was extremely pious; \\ but to him it was a manner hereditary. \\ Many of his forefathers were saints. ${ }^{1}$ \\ Jeanne Guyon \\ A new prophetess undertook to revive the Cuide of Molinos, \\ and the prayer that it teaches. She is full of this esprit, \\ this mysterious woman of the apocalypse; it is this child that is within her. \\ This woman's work is not finished.... \\ Jacques-Bénigne Bossuet
}

History best remembers Jeanne-Marie Bouviers de La Mothe Guyon as the degenerate bud from whom blossomed the unfortunate Quietist controversy. This event is well-known to French historians, as it involved a heated exchange between two of the most influential French churchmen of the seventeenth century: Jacques-Bénigne Bossuet (1627-1704) and François de Salignac de La Mothe-Fénelon (1651-1715). What continues to stimulate debate and controversy among scholars is the personality of Mme Guyon herself - some see her as a true prophet whose words are to be accepted and admired for their painful honesty; to others she is nothing more than an ignorant, greedy, and selfabsorbed woman whose meddling in Church affairs deservedly landed her in jail. It seems that when reading Mme Guyon, you either like her immensely, or

\footnotetext{
1 Jeanne Guyon, An Autobiography: Madame Guyon, trans. Gene Edwards (Chicago: Moody Press, 1970), 19. For the purposes of this thesis, this work will be referred to in the footnotes and the text as simply the Vie (referring to the original title, La vie de Madame Guyon).

2 Jacques-Bénigne Bossuet, "Relation sur le Quiétisme," in Oeuvres (n.p.: Bibliothèque de La Pléiade, 1960), 1172. All translations found in this thesis are my own unless stated otherwise.
} 
hate her passionately. The very presence of her strong, almost overbearing personality jumps out from the page as though three hundred years has done nothing to dilute its strength. She is a powerful force, someone to be reckoned with in any generation, and her superficial message is hypnotically attractive anyone can achieve some form of spiritual union with God. Sanctification comes not from attending mass, or weekly confessions, or even selfmortification; instead, it comes only from losing oneself in quiet prayer with the Lord. Such a message, while not original by any means, proves a dangerous potion when mixed with her fantastic, charismatic personality.

The overarching objective of this thesis is to examine Mme Guyon's role in the Quietist Controversy. is it really so simple to say, as many historians have done, that her famous and well-read tracts like The Short and Easy Method of Prayer (a translation of the French title Moyen court et très facile de faire oraison) and Spiritual Torrents (Les spirituals torrents) represent an elaboration of themes and methods suggested by earlier mystics such as St. François de Sales, St. Jeanne-Françoise de Chantal, and St. Teresa of Avila? Or is it, as other historians would have us believe, the fact that Mme Guyon's theories were soundly part of accepted Catholic theology and that the only cause for her condemnation was the fact that she was an outgoing, loud, and charismatic female?

A careful reading of the works of Mme Guyon reveals a woman who is obsessed with herself -- her salvation, her martyrdom, her popularity, and her 
superiority. Such a description fits perfectly into the much-ignored suggestion by Bossuet in his Relation sur le quiètisme that she saw herself as a living saint, above and beyond the mystics of the past, more powerful than the priests of the present, and positively ensured that she was the only true bride of Christ who would rule beside him in the future. Seeking to expand historical research which has so far focused on the post-Council of Issy period of this controversy, this thesis attempts to show that such emphasis may overlook the true roots of the debate. A careful reading of Bossuet and Mme Guyon, as well as other persons who participated in this debate, reveals that the so-called Quietist controversy was originally rooted in two things: Bossuet's distaste for Mme Guyon's assertions of saintliness, and her incessant conviction that such a statement was true. In these contexts, the self-canonization of Mme Guyon is crucial for understanding the debate and the course it took both before and after the Articles of Issy in March 1695. Using the goal of self-canonization as a focal point, this thesis suggests that Madame Guyon carefully, and intelligently, constructed her autobiography to resemble the lives of Catholic saints. Her purpose in this action was to convince her contemporaries that she was not only a living saint, but was the sole bride of Christ as represented by the woman of the apocalypse, which I interpret as being the highest level of saint in the Glorious Orders. Her refusal to conform to accepted historical images of Catholic saints, such as dismissing poverty and humility, had to be remedied by an autobiography which would justify these deviations. I believe that these 
grandiose assertions, which were compounded by her awkward but purposeful imitation of accepted mystical doctrine, led to her condemnation in the French Quietist debate of the late seventeenth century.

While there has been sporadic work in recent decades focusing on the controversy between Fénelon and Bossuet over Mme. Guyon, as a historical figure in her own right she has tended to receive limited attention. While many translations of Madame Guyon's writings are in circulation today due to her popularity in Evangelical Christian circles, there are few biographies and scholarly analyses of her life. General histories since her death, such as Voltaire's Age of Louis XIV and Pierre Goubert's Louis XIV and Twenty Million Frenchmen, speak of Mme Guyon only in the context of the great theological battle between Bishop Jacques-Bénigne Bossuet and Archbishop François Fénelon in the late seventeenth century. ${ }^{3}$ Many of these resources also provide a superficial examination of the doctrine of Madame Guyon only so far as it was incorporated into the works of Fénelon. ${ }^{4}$ For example, the writings of Elbert Hubbard about Mme Guyon in his Little lourneys to the Homes of the Great, places her in volume thirteen, Great Lovers. He is, of course, referring to Mme Guyon only in the context of her relationship, in this case sexual relationship,

\footnotetext{
${ }^{3}$ Pierre Goubert, Louis XIV and Twenty Million Frenchmen, trans. Anne Carter (New York: Vintage Books, 1970), 274-275; François Arouet (Voltaire), The Age of Louis XIV (New York: Everyman's Library, 1961).

${ }^{4}$ Sources which consider Mme Guyon as only a protogée of Fénelon include: Katherine Day Little, François de Fénelon: A Study of Personality (New York: Harper and Brothers Pub., 1951); Mme Duclaux, The French Ideal: Pascal, Fénelon, and Other Essays, trans. Mary Robinson (London: Chapman and Hall, 1911.
} 
with Fénelon. While the mass of research on Fénelon would attest to his popularity throughout time, study of his spiritual teacher leaves much to be desired. Indeed, few volumes have been written solely discussing Madame Guyon, and historians believe her autobiography to suffice as testimony about her life and inspirational teachings. ${ }^{5}$ Rather than being seen as the forerunner for the thought and works of Fénelon, she is viewed by many historians in passing as a crazy, sensuous, bored evangelist who warrants little discussion. Hubbard rebukes Mme Guyon in a way which is characteristic of much historical research about her: he calls her a type of woman "well-known to the pathologist." ${ }^{6} \mathrm{Her}$ autobiography is nothing more than a silly exercise in egotism, and Hubbard is clear when he relates his opinion about her: "The tragedy of her life lay in that she had a surplus of time and a plethora of money, and these paved the way for introspection and fatty enlargement of the ego." 7 This view, although extremely humorous, deserves further examination. The dismissal of Mme Guyon as silly or as the friend/lover of Fénelon does not give her the recognition she deserves as a major figure in the late seventeenth century.

Recent biographies, including Marie-Louise Gondal's Madame Guyon: Un Nouveau Visage and Jeanne Guyon by Francis Mallet-Joris, have focused on correcting the neglect and denigration of Mme Guyon, but still fall short of any

\footnotetext{
${ }^{5}$ The autobiography of Mme Guyon was originally titled La vie de Mme J.M.B. de La Mothe Guyon, écrite par elle-même and has been published in many languages since its first publication in Cologne in 1720.

${ }^{6}$ Elbert Hubbard, Little Journeys to the Homes of the Great, vol. 13. (Cleveland, OH: The World Publishing Co, 1928), 315.

${ }^{7}$ Hubbard, 315.
} 
real analysis of her influences and personality. In Un Nouveau Visage, Gondal attempts to reconstruct the roots of the Quietist debates of the 1690's, while also trying to situate the teachings of Mme Guyon within a larger framework of Protestantism. Focusing almost exclusively on the reactionary text of Bossuet, Relation sur le quiètisme, Gondal supported the assertion that Mme. Guyon was persecuted solely as a female version of Molinos. She stated that:

Pope Innocent [XI] had accredited the suspicion... Mme. Guyon did all simply as a part of the "sect of Quietists whose leader was Molinos." Bossuet resumed that argument. For him, "the Guide" of Molinos was the original for the new quietism and for the "Method of Prayer". ${ }^{8}$

Gondal paints a picture of the woman, Mme Guyon, seeking authority in the Church through her mystical experiences (as so many women before her had done). The real difference in the late seventeenth century was, for Gondal, the presence of the misogynist Bossuet, whose association of Guyon with Molinos was a convenient way for him disguise his hatred (and fear) of her gender. She suggests that the accusations of Bossuet were exaggerated by a theological society composed of men desiring to be rid of Mme Guyon's uncontrollable sensuality. In fact, Gondal includes an entire chapter dedicated to "a feminine menace" claiming that the Church response was from "fear of an uncontrollable issue ${ }^{\prime \prime}{ }^{9}$ The application of gender studies to the life of Mme Guyon will be addressed more satisfactorily in the final chapter of this thesis.

Other biographical works, such as the classic Life of Madame Guyon by the Congregational Minister Thomas Upham, seek to justify her every action in

\footnotetext{
${ }^{8}$ Marie-Louise Gondal, Madame Guyon: Un Nouveau Visage (Paris: Beauchesne, 1989), 78-79.

${ }^{9}$ Gondal, chapter 3, sections 1 and 2.
} 
hopes of validating their own brand of Quietist-based Protestantism. The most informative and authoritative analysis of Guyon remains Upham's Life and Religious Opinions and Experience of Mme. Guyon. This two-volume work, published in 1849 , has yet to be challenged in depth and historical research by any writer since. In a painstaking process, Upham recreates the almost daily events in the life of Mme. Guyon, including a surprisingly insightful discussion of her early life and marriage. The most valuable aspect of this work, however, is the discussion on Quietism in Chapter 19 (volume 2). There is no doubt that Upham (himself a "Quietist") believes that Mme. Guyon and Molinos were both of the same calling from God, and that they both were "possessors of the love implied in the doctrine [of Pure Love]." ${ }^{10}$ Upham fails completely in his discussion of Guyon's persecution to connect it to that of Molinos, choosing to bypass the accusations of Bossuet and the Council of Issy; in fact, the discussion of her condemnation and imprisonment in 1695 is filled with praise for her doctrine rather than actual historical retellings and analysis of the event. This could be attributed to the fact that, as a Quietist, he attempts to purge all evils associated with the doctrine -- what the reader does not know will not hurt him. Despite these failings, Upham's biography remains the central work on Mme Guyon, and will provide a pivotal reference for this thesis.

Following Upham closely in regards to style and interpretation is Michael de la Bedoyere's The Archbishop and the Lady. In a more historical, pro-Fénelon

\footnotetext{
${ }^{10}$ Thomas C. Upham, Life and Religious Experiences of Madame Guyon (New York: Harper and Brothers, 1858), 338.
} 
analysis, Bedoyere focuses momentarily on why the Quietists came under fire from the Jesuits and Jansenists. His sole explanation for this unfortunate fact is the writings of Molinos on the Canticle of Canticles in the Bible, discussing the union of man and God as being similar to marriage and carnal love. ${ }^{11}$ As a result, "it was very easy to associate Quietism with a hypocritical non-resistance on the part of self-constituted pious peoples to the sins of the flesh." ${ }^{12}$ Using this explanation as his premise, Bedoyere concludes by lengthy discussion that Molinos was punished for his Quietism by death because he was a man of the church who had sinned sexually. He says that:

Molinos's crime in the eyes of his enemies was that of sexual misbehaviors perpetuated under the cloak of a specially edifying and pretentious spiritual direction... What had been read in one way because it was believed that most Quietists were holy and earnest people, was now read the other way because it was suspected that all were associated with Molinos or were like him.

This passage leads the reader to believe that Bedoyere felt that the heavily-biased trial and unfair punishment of Molinos set the precedent for the treatment of Quietists throughout Christian countries. The added notion of sexual excess on the part of the Quietists also provides an interesting twist to traditional views of the controversy, one which is left relatively unexplained by Bedoyere. The passionate sexuality of the text of Mme Guyon, however, will tie in directly with analysis presented in this thesis, and these assertions by Bedoyere will be significant in the discussion that follows.

\footnotetext{
1 Michael de La Bedoyere, The Archbishop and the Lady: The Story of Fénelon and Madame Guyon (New York: Pantheon Books, 1956), 83.

${ }^{12}$ La Bedoyere, 84.

${ }^{-13}$ La Bedoyere, 88.
} 
Still other scholars, including Dorothy Gawne Coslet in Madame Jeanne Guyon: Child of Another World, seek to legitimize Mme Guyon by elevating her to the spiritual level of great religious men like Martin Luther and St. Augustine. Coslet is a participant in the late twentieth century revival of Mme Guyon as the most true and perfect Christian, and her biography provides a good example of how many contemporary theologians view Mme Guyon. To read this work, a veritable (unconfirmed) saint's life in itself, Mme Guyon is heralded as the most holy of women whose persecution was due to jealousy, misogyny, and general ignorance on the Church's part. She says in the chapter describing Bossuet's opposition that:

Although Bossuet was eager to extinguish any heretical deviation that came under his watchful eye.... It seemed inconceivable to him that Madame Guyon, or any woman for that matter, could produce such a heady stir in Paris, Versailles, and Grenoble that would be so very detrimental to the Church.... And he could not very well discount the fact that stable men... had come under this woman's influence and had been greatly affected and visibly swayed by her teachings. Thus it was that Bishop Bossuet decided that until he could learn more about Madame Jeanne Guyon firsthand he would bide his time and do nothing until he felt certain - and then he would strike! ${ }^{14}$

This sentimental style of writing, which surely seeks to engage the reader on the side of Mme Guyon, is typical of theological examinations of her. To use a reference from the Book of Revelation (chapter 12), Bossuet is the dragon of hell, and Mme Guyon is the gentle Bride of Christ who is pursued by her foe at every turn. What is interesting about this contemporary view of Mme Guyon is that it seeks to justify her position as the true spouse of God who begot his true 
spiritual children. To follow Mme Guyon's way, Coslet would say, is to be the genuine child of God, a theme which, in part, will be developed in the following chapters.

It must be mentioned that there are countless other sources which contain references, although small, to Mme Guyon which will become integrated in the analysis presented here. Most of these are biographies of Fénelon or Bossuet, and in almost all Mme Guyon is presented as an almost devilish freak who sought only to lure the innocent, pious priests to their fiery doom. ${ }^{15}$ An example of this writing comes from Fénelon by E.K. Sanders, in which Mme. Guyon is awarded an entire chapter. The slightly misogynistic descriptions of her provide little reference to the nature of her writings, but they do hint at a pre-Bedoyere description of her sexuality. Sanders claims that Mme Guyon had not been afraid to experience physical sensations as part of her strict religious regimen:

It is hard to understand how a woman, whose mind centered on contemplation of the love of God, could tear her flesh with pointed spikes and bruise herself with whips and nettles, with the deepest assurance that she thus did him honor. ${ }^{16}$

While such an assertion is, at most, highly questionable (with no references provided for the reader), it is perhaps an example of how Mme Guyon is seen as a sensual creature, one who actively pursues physical pleasure, and pain, from Christ. This author also expressed another interesting characteristic of Mme

\footnotetext{
${ }^{14}$ Dorothy Gawne Coslet, Madame Jeanne Guyon: Child of Another World (Washington, PA: Christian Literature Crusade, 1984), 162.

15 Duclaux, 140-147.
} 
Guyon which may have had some bearing on her treatment by the Church and Monarch -- her self-righteousness. Sanders states that, "it is strange that, with all her self-examination, she never realized her own egotism." ${ }^{17}$ It becomes obvious to the reader of Moyen Court de faire Oraison or her autobiography that Mme. Guyon truly believed that she was a chosen one, much in the same way as the Virgin Mary was chosen to serve divine will by carrying the unborn Christ. An interesting proposition put forth by Sanders, this aspect of Mme Guyon seems to have far- reaching implications.

As the above discussion shows, historical concentration on the influential theological and social personality named Jeanne Guyon as so far revolved around three key factors: her female sensuality, her doctrinal vindication, and her association with influential church men. Each of these positions will come into play in the examination of Mme Guyon's works presented here, as it appears that a combination of suggestions by various scholars leads to an expanded discussion and assessment of Mme Guyon.

She was born into the family of the Seigneur de La Mothe Vergonville in Montargis on April 18, 1648. Jeanne-Marie Françoise Bouvier de La Mothe grew to young adulthood while being tossed between Ursuline and Benedictine Seminaries. Her religious background included reading the works of St. François de Sales and Mme de Chantal, both of whom she credited with her decision to become a nun at fourteen. However, obsessed constantly with feelings of

\footnotetext{
${ }^{16}$ E.K. Sanders, Fénelon: His Friends and His Enemies (London: Longmans, Green, and Co., 1901), 94.
} 
sinfulness and betrayal of God, she agreed to be married at sixteen to $M$. Jacques Guyon de Chesnoy, a thirty-eight year old invalid. As she stated in her autobiography, "No sooner was I at the house of my husband, than I perceived it would be for me a house of mourning. ${ }^{18}$ She bore M. Guyon several children before his death in 1676, after which she became thoroughly involved with preaching her mystical doctrine best titled Guyonism.

After several lengthy religious missions into Switzerland and the Dauphiné region of France, she returned to Paris in 1686. There she became wildly popular among the nobility; the number of influential persons who filed into her parlor was outstanding, and included Mme de La Maisonfort (Mme Guyon's cousin), the duc and duchess de Béthune, the duc and duchess de Beauvilliers, the duchess de Chevreuse (daughter of Jean-Baptiste Colbert), and several family members of former superintedant of finances Nicolas Fouquet. ${ }^{19}$ For almost a year she enjoyed celebrity status, walking freely in the gardens of Versailles and all the time gathering several of the court around her cause. Her influential connections even landed her an interview with the Queen, Mme de Maintenon, who was so enthralled with Mme Guyon that she made her senior lecturer at the celebrated St. Cyr Seminary for girls. However, due to untraceable reasons, her confessor and partner in Guyonism, Father La Combe, began to be closely examined by religious authorities. A brew of trouble was further stirred

\footnotetext{
${ }^{17}$ Sanders, 98.

${ }^{18}$ Guyon, Life, p. 51.

${ }^{19}$ Mme Guyon's favorite child, Jeanne-Marie Guyon (1676-1736) had married M. Fouquet's son and heir, Louis-Nicholas Fouquet, comte de Vaux, in August of 1689.
} 
by her own brother, Paris Barnabite leader Pére La Mothe, who suggested that she was a heretic to M. de Harlai, Archbishop of Paris. Louis XIV, concerned with her influence at court, had her placed in the Convent of Ste. Marie under guard for several months in February 1688, and it was there that she was inspired to write her autobiography.

In late 1688 Mme Guyon met Jesuit priest, Père François Salignac de La Mothe Fénelon (1651-1715), during a hiatus from imprisonment. The son of comte Pons de Salignac, Fénelon had been trained in theology at the respected Seminary of Saint Sulpice. His success with ministering to the Protestants and New Catholics in Poitou, coupled with his growing reputation as an excellent writer and teacher, brought him to the attention of Louis XIV. The King, under the suggestion of Jacques-Bénigne Bossuet (1627-1704), the influential and experienced bishop of Meaux, appointed Fénelon as Preceptor to the Dauphin in 1689 , one of the highest positions that could befall any Frenchmen. Shortly before being granted this honor, Fénelon had been overtaken by the heavenly claims of Mme Guyon and became her foremost supporter. The relationship was to have eternal consequences, and despite the cooling of their relationship months before she was to meet Bossuet for the first time, the future Archbishop of Cambrai proved her greatest ally during and after her investigation by the Council of Issy from 1694 to 1695.

This Council was led by Bossuet, who is possibly one of the greatest Catholic orators and theologians. After completing his Doctor of Divinity degree 
under the direction of St. Vincent de Paul in 1652, he was encouraged by his advisor to go to Paris in order to better serve the King. This move facilitated his rapid promotion, including appointment to the offices of bishop of Condom and Preceptor to the Dauphin in 1670. After this latter position ended in 1680 , Bossuet was appointed bishop of Meaux. One hundred and thirty works were completed by Bossuet between 1653 and his death in 1704, including many panegyrics for various saints, and several lengthy funeral orations for royal persons including Gaston d'Orléans (brother of Louis XIII) and Henriette-Anne, wife of Louis XIV's brother Philippe. Bossuet was drawn into the controversy surrounding Mme Guyon in late 1693, and became head of the Council of Issy which declared her a heretic in 1695.

Some time after this declaration, she spent five lonely years in the Bastille as a religious prisoner. Yet, despite her continuing unpopularity within the church and monarchy, she was released in 1702 and sent to live with her eldest son at his estate in Blois. For the next fourteen years of her life, Mme Guyon continued to preach to a select group of foreigners which made up her "little Church of devotees." ${ }^{20}$ After she died on June 9, 1717, Protestant leaders in Europe, including Wettstein, Lord Forbes, and Paul Poiret, adopted her writings as proof of a new, emotional spirituality. This association continues to flourish.

\footnotetext{
${ }^{20}$ Bedoyere, 241. Mme Guyon often referred to her followers as her children given to her by Christ, a theme which will play a key role in later chapters of this thesis.
} 
In order to make sense of Mme Guyon's interpretation of herself, this thesis seeks to unite various aspects of her writings and personality, including the imagery of the Book of Revelation, sainthood, mysticism, sensuality in reference to Jesus, and persecution. After a discussion of the Quietist debate of France in the late $1690^{\prime}$ s, in which Bossuet proclaimed her sarcastically a saint and the apocalyptic bride of Christ, I will turn for a moment to an examination of Catholic saints for the purpose of providing a background for her motives. To be a saint was to have power, celebrity, admiration, and immortality, and Mme Guyon doesn't miss a beat as she attempts to construct herself as one of God's chosen few by carefully constructing an autobiography - a virtual saint's life -which could support this assertion. Here, the aspects of her life which do not coincide with accepted Catholic sanctity will be examined closely in order to show how her autobiography was supposed to serve as a correction for these deviations. Intimately coupled with this assertion was Mme Guyon's belief that she had attained the highest level of sainthood possible as the true bride of Christ, represented in the imagery of the woman in the Book of Revelation. It is here that the sensual aspects of her writing gain full attention, as Mme Guyon develops a tri-fold image of Christ as a lover, as a spouse, and as a seducer. As well, the vision of the woman of the apocalypse provides further clarification for Mme Guyon's obsession with maintaining persecution of herself and her doctrine. A final chapter will attempt to provide answers to questions raised by historians. Was she a saint, a heretic, or both? Was Mme Guyon an ignorant, 
hysterical fool? And, addressing modern concerns, what role did misogynism play in the Quietist controversy? Through the thoughtful association of many aspects of her writings, this thesis suggests that Mme Guyon did, indeed, consider herself the woman of the apocalypse, and I believe that this vision was the key to Bossuet's condemnation of her in the Quietist Controversy. 


\title{
Chapter 1 \\ A Challenge to Sanctity: The "Quietist" Controversy
}

\begin{abstract}
"But the most violent assaults that the interior Christian will know come from Christians who pretend - the ones who have a devotion to God, a false devotion. There is a foul character within these people, a wickedness of hypocrisy. The internal one recognizes this, and in some way this recognition provokes hostility from those who oppose the interior way. It seems almost like a conflict between devils and angels." ${ }^{21}$

Jeanne Guyon
\end{abstract}

Oh God, what corruption! Have mercy on Your Church! Voices are raised against those who worship God in their heart... Are some even canonized? Esteemed? Applauded? And those disgraced and considered as the worst of men are, on the contrary, burning with pure love, shun glory, honor, esteem of men, looking only to God - their only aim! Evil is become good, and good,... evil! ${ }^{22}$ Jeanne Cuyon

Mme Guyon and her true intentions can only be understood by placing her within the historical context of her greatest achievement - the spawning of the so-called Quietist Controversy in the 1690 's. No matter how esteemed she is within Quaker or Evangelical Christian circles, Mme Guyon is remembered by authors and historians alike as the crazed woman who ruined the esteemed careers of the two greatest Churchmen in France. This chapter seeks to outline this disagreement, and proposes that the attack upon Mme Guyon headed by the archbishop of Meaux, Jacques-Bénigne Bossuet, was inspired by something beyond Quietism.

${ }^{21}$ Jeanne Guyon, Final Steps in Christian Maturity, trans. George McCall (Auburn, Maine: Christian Books Publishing House, 1985), 68.

${ }^{22}$ Jeanne Marie de La Mothe Guyon, Christ Our Revelation, Trans. Gene Edwards (Sargent, GA: Seed Sowers Press, 1985), 63-64. Referred to in the footnotes as Revelation.

Revelation. 
The controversy surrounding Quietism in the late seventeenth century was not isolated to France. The debate over this dangerous doctrine of Pure Love had been raging in Catholic countries since the surprising arrest of the Spanish priest Miguel de Molinos in 1685 . While quietist forms of mysticism had existed before Molinos, he is credited for actually bringing the term into existence. ${ }^{23}$ Despite his privileged status as a favorite speaker at the Vatican, Molinos was accused by Cardinal d'Estrées, the French Ambassador at Rome, arrested, and found guilty by the Inquisition for heresy. Pope Innocent $\mathrm{XI}$ issued the Bull "Coelestis Pastor" in November 1687 which condemned the Guida Spirituale and all of Molinos's other teachings and writings. Immediately more than two hundred persons in Rome found themselves implicated as Quietists. Whole communities of nuns and monks were tried and found guilty by inquisitorial proceedings which lasted until the eighteenth century. Molinos himself escaped execution, but was imprisoned in a Roman cell for eleven years until his death in 1696.

The Molinos Affair was in many ways a response of the counterreformation within the Catholic Church seeking to eliminate any doctrines which did not conform to accepted dogmas of Church authority. By preaching Quietism, Molinos was removing the Church entirely from the process of sanctification by insisting that a middleman - a confessor and the mass - was unnecessary. Instead an individual could follow a mystical path of silent prayer,

${ }^{23}$ Quietism is best described as a mystic belief which enjoins passive contemplation and the blissful 
becoming united with God in an intimate way that could never be reproduced by Church ritual. In many ways the Quietist adhered to the accepted methods of mystical union with God as established in previous centuries. However, Molinos brought a different twist to the traditional experience by making the soul completely passive:

By not speaking nor desiring, and not thinking, she [the soul] arrives at the true and perfect mystical silence wherein God speaks with the soul, communicates Himself to it, and in the abyss of its own depth teaches it the most perfect and exalted wisdom. He calls and guides it to this inward solitude and mystical silence, when He says that He will speak to it alone in the most secret and hidden part of the heart. ${ }^{24}$

This is not an impressive, radical notion of the Interior Silence; rather for much of the Cuida Spirituale he is speaking the accepted language of all mystics.

What made Molinos such as threat to the Church was his suggestion that there was a extraordinary virtue in doing nothing at all, and subsequently that all spiritual activities, whether they be praying before sleep or speaking with a confessor, were bad. ${ }^{25}$ This is essentially why he was condemned as a heretic by the Catholic Church, who felt in many ways threatened by a rejection of traditional ritual and prayer. Thus in the late seventeenth century, anyone who was seen as being remotely Quietist was condemned by the Church leaders.

annihilation of the will, or joyful self-annihilation.

${ }^{24}$ Miguel de Molinos, The Spiritual Guide which Disentangles the Soul (London: Methuen and Co., 1927), prop. $2-13$.

${ }^{25}$ Evelyn Underhill describes this "particular virtue" at length in Mysticism (New York: E.P. Dutton, 1911), chapter VI. 
When Jacques-Bénigne Bossuet published the Articles of Issy in March 1695, the result of a conference between himself and two other Churchmen, he stated that Mme Guyon's main heresy was that of Molinosism. His subsequent examination of her works led him to believe that, despite her convictions to the contrary, she did possess a great deal of similarities with the heretical Spanish priest. In his Relation du Quietisme (1698), Bossuet repeatedly accused Guyon of having been a student of Miguel de Molinos's Quietist teachings. Not only that, Bossuet claimed that Mme Guyon's texts, especially the Moyen court et très facile pour l'oraison que tous peuvent pratiquer très aisément (The Simple and Easy Method of Prayer), were simply fine copies of Molinosism that she had lifted from his Guida Spirituale. Bossuet called her a "new prophet venturing to revive the Cuide of Molinos. ${ }^{26}$ Considering the atmosphere of the time, one in which any heretical teachings were being adamantly attacked by a Catholic Church determined to maintain control in light of growing Protestantism, it would be easy to pass off the Quietist Debate in Louis XIV's court as being just that - a debate between church authorities as to whether Mme Guyon was a follower of Molinos or not. Certainly, there are many scholars who have chosen to do so, and have passed over this crucial period with little interest. ${ }^{27}$ While

\footnotetext{
${ }^{26}$ From Jacques Bénigne-Bossuet, "Relation sur le Quiétisme," in Oeuvres (n.p.: Bibliothèque de La Pléiade, 1960), 1172. This work will be referred to throughout the footnotes as simply Relation.

${ }^{27}$ This is a common view in many texts which include this controversy. See for example: Alfred Rébelliau, Bossuet, Paris: Librarie Hachette, 1912.; François Arouet (Voltaire), The Age of Louis XIV, New York: Everyman's Library, 1961.; Patrick Laude, Approches du quiétisme: deux etudes, Paris: Papers on French Seventeenth Century Literature, 1991.; Louis Guerrier, Madame Guyon: sa vie, sa doctrine et son influence, d'aprés les ecrits originaux et des documents inedits, Paris: Didier et cie, 1881.; Thomas Upham, Life and Religious Opinions and Experiences of Madame Guyon. Vols. 1 \& 2. New York: Harper and Brothers, 1858.
} 
this might seem attractive to some, such a simple explanation is not sufficient. The writings of Bossuet against Mme Guyon during this debate focused on something more than her possible association with Molinos. The following section will thus present evidence that Bossuet was perhaps more concerned with Mme Guyon's claim of sanctity than he was with her quietist leanings.

In September of 1693, Jacques-Bénigne Bossuet, bishop of Meaux, met Jeanne de La Mothe Guyon for the first time. There is no doubt that he must have heard of her several years before this time, as her questionable teachings at Mme de Maintenon's beloved girl's convent school at Saint-Cyr had made Mme Guyon a popular topic of conversation in court circles. The initial reason for the meeting is entirely unclear, although it does seem that the Bishop of Meaux intentionally sought out Mme Guyon through the Duc de Chevreuse, a mutual acquaintance. Many authors portray Bossuet in late 1693 as a man with a violent mission against all heresies, and who was passionately seeking them out. Dorothy Coslet writes in her biography of Mme Guyon: "Thus it was that Bishop Bossuet decided that until he could learn more about Madame Jeanne Guyon firsthand he would bide his time and do nothing... until he felt certain - and then he would strike!" ${ }^{28}$ While this position may be too presumptive, it is probable that Bossuet may have been concerned about Guyon's growing influence. Historian E.E. Reynolds suggests that Fénelon may have been at the

\footnotetext{
${ }^{28}$ Dorothy Gawne Costlet, Madame Jeanne Guyon: Child of Another World (Ft. Washington, PA: Christian Literature Crusade, 1984), 162.
} 
root of introducing the two, and says that he may have intended to enlighten Bossuet in regards to the inner way "because of the high regard he had for his mentor. ${ }^{29}$ According to Reynolds, Bossuet was "not anxious to undertake the inquiry; he had other matters on his hands," including the controversy surrounding heretic Richard Simon. ${ }^{30}$ While the reasons for his doing so may never come to light, Bossuet did indeed agree to meet with Mme Guyon in late 1693.

One of the extant accounts of this crucial meeting is written several years after the event by Mme Guyon in her Vie. She says little about it, which is surprising considering the immense effect it would have on her life. She writes:

At this time I have my first acquaintance with the Bishop of Meaux. I was introduced by an intimate friend, the Duke of Chevreuse. I gave him the foregoing history of my life, and he confessed, that he had found therein such an unction as he had rarely done in other books, and that he had spent three days reading it, with an impression of the presence of God on his mind all that time. ${ }^{31}$

Thus, it appears from the account of Mme Guyon that, at first, Bossuet was overcome with the holiness of her text. In fact, at this time she gave him copies of her other works, including the Moyen court and the Bible commentaries, which she does not mention in this passage, perhaps feeling that they did not reveal her true sanctity as well as her autobiography did. For a time she was

\footnotetext{
${ }^{29}$ E. E. Reynolds, Bossuet (Garden City, NY: Doubleday and Co., 1963), 217.

${ }^{30}$ Reynolds, 218.

31 Jeanne Guyon, An Autobiography: Madame Guyon, trans. Gene Edwards (Chicago: Moody Press, 1995), 374. For the purposes of this thesis, this work will be referred to in the footnotes and the text as simply the Vie (referring to the original title, La vie de Madame Guyon).
} 
correct, as it appears that Bossuet was overcome with "the presence of God" in her Vie. ${ }^{32}$

They did not meet again until January 30,1694 , at which time it appears sme initial, but rather minor, concerns about the texts he had - 'Mme Guyon's Vie, Bossuet made no reference at this meeting

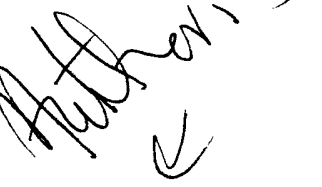
;hip of her writings to those of Molinos. It seems, rather, that rn the Bishop of Meaux had at the time regarded the issue of authority. Bossuet was concerned that Mme Guyon was not truly speaking the word of God, but perhaps had been inspired by some other (unholy) source. She writes that, "he admitted that looking into the ecclesiastical histories for ages past, we may see that God has sometimes made use of laymen, and of women to instruct, edify, and help souls in their progress to perfection." ${ }^{33}$ Thus, while "advanc[ing] all of his objections," Bossuet was trying to find justification for her teachings by saying that, at least initially, God was perhaps using her as a tool to deliver his message to the world. Mme Guyon was very aware of her position, and claims to have alleviated some of his worries by saying:

I think one of the reasons of God's acting thus, is that glory may not be ascribed to any, but to Himself alone. For this purpose, He has chosen the weak things of this world, to confound such as are mighty ( 1 Cor. $1: 27)$. Jealous of the attributes which men pay to other men, which are due only to Himself, He has made a paradox of such persons, that $\mathrm{He}$ alone may have the glory of his own works... I am only a poor nothing. God is all-powerful. He delights to operate, and exercise His power by mere nothings. ${ }^{34}$

\footnotetext{
${ }^{32}$ Guyon, Vie, 374.

33 Guyon, Vie, 374.

${ }^{34}$ Guyon, Vie, 374-375.
} 
The initial concern of Bossuet was not that Mme Guyon was a Quietist and a heretic. He was, rather, only interested in her justification of why it was that God had chosen her the be his mortal voice.

In his own account of his initial impressions of her given in Relation sur le Quiétisme, composed by Bossuet in 1698, Bossuet never mentions that he had originally thought of Mme Guyon as a Quietist, or for that matter, that she in any way resembled Molinos. In fact, Bossuet seems most interested in the astonishing manner by which Mme Guyon would convey God's grace to others. He says in chapter II, point 3 , during a description of his first impressions of Mme Guyon that:

I found in this Lady's Vie that God had given her an abundance of graces of which she was bursting at the seams. Sometimes it was necessary for her to release some of the overwhelming pressure caused by having so much of God's grace..... Often one could release this pressure by sitting next to her. By this manner, they would come to receive the grace she was full of, and this was the only manner which could relieve this situation. $^{35}$

Thus, at least initially, Bossuet describes his concern with Mme Guyon's claim of a superabundance of God's grace. Confronting her about the miraculous passing of such a mystical gift from herself to others, Mme Guyon responded verbally to him during an interview that, "these graces were not for her. She had no need of them, being otherwise full, and that this superabundance was for others." ${ }^{36}$ Bossuet concludes that this astonishing transmission of grace caused

\footnotetext{
${ }^{35}$ Relation, 1105.

${ }^{36}$ Relation, 1105.
} 
him initially to suspect her works as problematic: "All appeared to me at first to be new, superb, and extraordinary, and a little suspicion, and my heart, progressively rose up against the doctrine in the books I had read. I was unable to resist this manner in which God conveyed his grace." ${ }^{37}$ Such a conviction, which he found tantalizingly incredible, inspired Bossuet to examine Mme Guyon further, but with careful moderation.

Desiring to gain more insight into her doctrine, in September 1963 and again in January 1694, Bossuet requested to read more of her writings. Despite her concern that he suffered from an "unacquaintance with the inner paths," she presented to him Spiritual Torrents and some of her poems. ${ }^{38}$ He says that before accepting any of her printed materials in September of 1693, "I wanted to proceed moderately, and to condemn nothing in depth before having seen everything." ${ }^{39}$ This marks the beginning of important correspondence between the Bishop of Meaux and Mme Guyon which would occupy the next four months.

Between February and May in 1694 Mme Guyon continued to preach her doctrine of simple and easy prayer to her noble audience, which included the queen, Mme de Maintenon. It appears that Mme Guyon was overly confident after the January meeting with Bossuet, and she thus went about her business normally as though his initial confirmation of her writings would soon inspire

\footnotetext{
${ }^{37}$ Relation, 1105.

38 Guyon, Vie, 374.

${ }^{-39}$ Relation, 1105.
} 
him to become one of her followers. In late February Mme Guyon wrote to Bossuet saying:

For some days, Monseigneur, I have been feeling a very true union with your soul. As this never happens to me without some special purpose of God, I beg you to expose yourself to the Divine eyes, both spirit and heart open, so that God can place there what it pleases him. Deliver yourself to the eternal purposes for your soul, and accept, if you will, all the ways that he will use to reign more completely in you than ever before. $^{40}$

This passage is crucial for several reasons. First, it demonstrates that Mme Guyon, as of early 1694, was not feeling under attack by Bossuet. Secondly, she was attempting to win him over with her charismatic spirituality (which had worked so well with others in the past). More importantly, she wants Bossuet to know that God is speaking through her, and that if he will let her instruct him, only then will he truly be in the service of God. She attempts to lure Bossuet to her thinking by claiming that God had instilled in her Divine knowledge of Bossuet's present spiritual condition. There is no question who the authority is in this passage; Mme Guyon claims it for herself in the name of God, and promises to help Bossuet achieve a similar level of spirituality. Mme Guyon clearly did not feel that the Bishop of Meaux was close to God because he did not adhere to the inner way - preferably, her inner way. Thus Mme Guyon, convinced that she was making progress in convincing the stern Bishop of Meaux of her sanctity, was absolutely determined to gather such a valuable lamb into her flock.

${ }^{40}$ Quoted from Reynolds, 222. 
Guyon supporters have questioned the level of Bossuet's knowledge about mysticism in general in an attempt to undermine his accusations against their heroine. Mme Guyon herself asserted the Bossuet knew nothing of the inner way. Writing to Bossuet in February 1697, Fénelon said to his opponent, "You frankly admitted to me that you have never read the works of St. Francis de Sales nor those of Blessed John of the Cross." ${ }^{41}$ This accusation may have been true to an extent, but as E.E. Reynolds points out, "St. Francis de Sales dominated French religious thought during the seventeenth century." ${ }^{42}$ It is thus inevitable, especially considering that St. Francis had been recently canonized in 1665 , that Bossuet had at least some knowledge of his teachings. On the other hand, Bossuet's knowledge of St. John of the Cross may have been lacking, but he was very learned on the way of St. John's spiritual mother, St. Teresa of Avila. In a letter to Mme Guyon dated March 4, 1694, Bossuet said:

I have never had any doubt whatever about the experiences of St. Teresa because I have never found in her writings anything contrary to the Scriptures, a fact she herself said had been recognized by the theologians of her day. That is what led me, thirty years ago, to accept unhesitatingly her doctrine which is also praised by the whole Church, and now that I am rereading the greater part of her works, I feel just the same. ${ }^{43}$

Bossuet was not unfamiliar, at least to some extent, with the manner of writing which Mme Guyon had undertaken. However, it appears that he had a working knowledge of mysticism, although he certainly did not embrace it wholeheartedly.

${ }^{41}$ Quote taken from Reynolds, 218-219.

${ }^{42}$ Reynolds, 219. 
Over the course of early 1694, Mme Guyon tried to persuade Bossuet as to her status as chosen one of God. The two wrote many letters back and forth, until Bossuet finally attempted to end their association in June. He did not condemn her writings as being heretical at this time, but he did suggest that she was fostering self-love by her assertions of saintliness. He wrote to her:

Among the things you must put aside are predictions, visions, and cures, in a word, all that is extraordinary, however ordinary it may seem to you in certain states; for all these things tend to nourish self-love unless one takes great care. ${ }^{44}$

Thus, after reading her autobiography, the Moyen court, and other pieces, it was clear to Bossuet that Mme Guyon was practicing self-righteousness. By acting as though she were a saint, by performing miracles, receiving divine prophesy, and living in a constant state of visions, and by endlessly talking about these things as though she was superior to others, she was practicing self-love - not selflessness that someone who was truly following the inner way of Quietism (or accepted mysticism) would display. By June 1694, Bossuet seems to have been convinced that Mme Guyon was not a true Quietist because of her flamboyant bragging, her excessive worldliness, and her phenomenal preternatural powers which contradicted the subservient, quiet, reserved teachings of Molinos.

While he may have been convinced that Mme Guyon was not a follower of Molinos at this time, in June 1694 it appears that Bossuet was ready to drop the examination of Mme Guyon in order to concentrate on other Church

\footnotetext{
43 Quote taken from Reynolds, 220.

44 Quote taken from Reynolds, 223.
} 
matters. Indeed, the intellectual battle he had been waging against Jansenists and Protestants was far from over. Not willing to allow him to dismiss her with a simple wave of his hand, Mme Guyon wrote again to Bossuet under the pretension of needing spiritual advice, but this action was not without purpose. By this time, Mme de Maintenon was actively opposing Mme Guyon due to her damaging influence on the young girls at St. Cyr Seminary. The teachings of Mme Guyon at the school had caused the students to neglect their duties, and instead many chose to sit praying in their rooms all day. This may have seemed to some a positive change, but the immediate result at St. Cyr was a collapse of order and discipline, which horrified Mme de Maintenon. With the wife of the King against her, Mme Guyon's other noble friends found it difficult to remain faithful to her. During this same time, one of her greatest and most powerful supporters, M. Fouquet (son of the imprisoned former minister of Louis XIV), died, thus leaving her more vulnerable than ever to criticism. Instead of dropping out of sight, or leaving Paris, to wait until the situation cooled, Mme Guyon wrote a note to her friends claiming that she would soon die. In her Vie she wrote:

Determined to retire out of the way of giving offense to any, I wrote to some of my friends, and bade them a last farewell; not knowing whether I were to be carried off by the indisposition which I then had, which had been a constant fever for forty days past, or to recover from it. ${ }^{45}$

She then sent some spiritual letters to persons whom she thought could use the spiritual advice after she was dead. This sentiment, however, seemed to fade

\footnotetext{
${ }^{45}$ Guyon, Vie, 376.
} 
quickly, and by mid-June Mme Guyon insisted that a layman examine her works further. This was to the disliking of Mme de Maintenon, who interfered long enough to appoint three ecclesiastics to the Council of Issy, officially charged in July 1694 with examining the works of Mme Guyon.

This Council met from July until March of 1695, during which time the writings of Mme Guyon were condemned as being heretical because of their similarity to the Quietism of Molinos. While Bossuet certainly was the member most familiar with Mme Guyon personally, two other Church intellectuals also passed judgement on her. The first was Louis Tronson (1622-1700), Superior of the Seminary of St. Sulpice where Fénelon had received his formal education. The choice of Tronson by Mme Maintenon and Bossuet was crucial, as it may have been an attempt by them to lure Fénelon back from his wandering ways. The Archbishop of Cambrai considered Tronson his mentor and spiritual confessor, and the influence which Tronson might have wielded over his former student was potentially quite considerable. There can be no doubt that an official condemnation of Mme Guyon by Tronson might have influenced the still-respected Fénelon to rejoin the Church in his former capacity; indeed, this is what eventually happened in 1700 . The third member of the Council of Issy, the Bishop of Châlons and future Archbishop of Paris, Louis-Antoine de Noailles, had been Fénelon's college companion at the Seminary of SaintSulpice and had also been a student of Tronson. Fénelon and De Noailles had shared a close friendship up until the Archbishop's questionable association with 
Mme Guyon, and there is little doubt that the Bishop of Châlons also sought to bring his companion out of the darkness he was trapped in.

By the time the Council sat down together in Issy, Mme Guyon's fate may have been sealed. Certainly, with the membership of the Council, there can be little question that their purpose was to bring their friend back into the accepted folds of Church doctrine, and out of the charming arms of Mme Guyon. To do so, she must be condemned, but in a way which was justifiable and logically arguable. For Bossuet to declare Mme Guyon a heretic based on his dislike for her character, or for his own belief that she was not the saint she professed to be, might be considered a personal vendetta and would not carry the same weight. Therefore, to convince Fénelon of her false greatness, the Council found it necessary to associate her with the current mystic heretic, Miguel de Molinos. When the Council of Issy published its thirty-four propositions against Mme Guyon in March 1695, her doctrine was accused of having been drawn almost exclusively from Molinos's teachings. ${ }^{46}$ An itemized discussion of what passed between the members of this Council is given in Bossuet's later work, Relation sur le Quiétisme (1698). Bossuet asserts that she was "a new prophetess who undertook the revival of the Guide of Molinos. ${ }^{147}$ He sarcastically relates that, "I use soft words in calling her a second Molinos." ${ }^{48}$ Later, he claims that Fénelon sought to support the writings of Mme Guyon in order to save those of

\footnotetext{
${ }^{46}$ Bossuet's Relation sur le Quiétisme, chapter four, has a more detailed description of the conversations between himself and the others on the Council which ultimately led them to this conclusion.

47 Relation, 1172.
} 
Molinos: "it was to rescue them [Mme Guyon's books] that he spared condemning the Guide of Molinos, which is the original." ${ }^{49}$ Prominent Jansenist leader Pierre Nicole, readily adopted the declarations of the Council of Issy, condemning Mme Guyon publicly as a new Molinos. In his Réfutation des principales erreurs quiétistes, Nicole assails Mme Guyon as the head of a French "sect of quietists whose chief was Molinos." ${ }^{50}$ Even Pope Innocent XII, after the matter came to his attention by way of King Louis XIV, accepted this conclusion. ${ }^{51}$ He was so concerned about the heresy of Molinos spreading within French borders that he ordered Louis XIV to release archbishop Fénelon from his esteemed position as tutor to the dauphin in 1697. Mme Guyon herself was extremely familiar with the charge of heresy as a Molinosist; in her autobiography, Mme Guyon describes the final declarations of this committee against her with much disgust. Aware that she was being called a second Molinos, Mme Guyon attempted to defend herself against the her Catholic critics by exclaiming, "I, who never knew there was a Molinos in the world, till the Gazette told me of it." ${ }^{52}$

The association of Mme Guyon's doctrine of mysticism and Molinos's Quietist teachings is highly problematic, and possibly entirely incorrect. Despite the conclusions of l'abbé Charles Libouroux, who asserted definitively in his

\footnotetext{
48 Relation, 1100.

49 Relation, 1173.

${ }^{50}$ Pierre Nicole, Réfutation des principales erreurs quiétistes, contenues dans les livres censurés pas l'ordinance de Mgr. L'archevêque de Paris du 16 octobre 1694 (Paris: Chez Guillaume Desprez, 1695),3.
} 
1876 dissertation that, "After analyzing these [texts] again, one is able to see that Mme Guyon had reproduced in her book [Moyen court] the mystical theories of Molinos. ${ }^{153}$ Libouroux does not stand alone in making this assertion. Most general discussions of Mme Guyon and the debate between Bossuet and Fénelon refer to it as the "Quietist Controversy," and turn it into a fight between the "Bossuettistes and Féneloniens." ${ }^{54}$ This view makes the entire situation dismissable, as though there is nothing left to be said; however, it does not reflect the original opinion of Bossuet, and appears to have been invented to facilitate Mme Guyon's unqualified condemnation.

When this view is questioned, based on the evidence presented above, the personal interactions between Bossuet and Mme Guyon take on an expanded meaning. In her sweeping account of the history of mysticism, Evelyn Underhill states that:

the accusation of Quietism has been hurled at mystics whose only fault was a looseness of language which laid them open to misapprehension... "Quietism," usually, and rather unfairly, regarded as the special folly of Madame Guyon and here disciples, already existed in a far more dangerous form in the Middle Ages.... ${ }^{55}$

Underhill continues by saying, "It is only fair to Madame Guyon to say that she cannot justly be charged with preaching this exaggeration of passivity

\footnotetext{
${ }^{51}$ Innocent Le Masson, La vie de Messire Jean d'Arenthon d'Alex, évêque de Genève (Lyon: Chez François Comba, 1699), 17.

52 Guyon, Vie, 359.

${ }^{53}$ Charles Libouroux, Controverse entre Bossuet et Fénelon au sujet du quiétisme de Madame Guyon (Rochefort: Chex Thèze, 1876), 136.

${ }^{54}$ François Mallet-Joris gives names to these two camps in her Jeanne Guyon (Paris: Flammarion, 1978), chapter ix.

${ }^{55}$ Underhill, Mysticism, 322.
} 
[Quietism], though a loose and fluid style has allowed many unfortunate inferences to be drawn from her works." ${ }^{56}$ Thus, for Underhill, one of the most admired scholars of mysticism in the twentieth century, Mme Guyon was not a true Quietist and could not, in truth, be justly associated with Molinos by anyone who was familiar with Quietist writings.

While there are indeed some striking similarities between Molinos and Mme Guyon, the most blatant being the imprecise concept of Pure Love, there are major differences which also must be examined. The true distinction between Mme Guyon and Quietism is the notion of "holy indifference." In the Moyen court, she states:

On occasion some people have heard that term "the prayer of silence" and have concluded that the role the soul is to play in this prayer is one of dullness, deadness, and inactivity. This, of course, is not the case.... The soul can be active and yet utterly silent. This is because it is the Lord Himself who has become the mover of the soul. The soul acts in response to the moving of His spirit.... Therefore, let the soul do nothing of itself in prayer. The soul must simply follow the Spirit until it reaches its ultimate end! ... We are not promoting the idea that the soul should be lazy or inactive. We are encouraging the highest activity the soul can engage in: total dependence on the Spirit of God. ${ }^{57}$

In this passage, Mme Guyon is encouraging her readers that once they enter on the way to union with God, he will take over all efforts and will draw the soul along a path until it becomes one with him (of course, this process only applies

\footnotetext{
${ }^{56}$ Underhill, Mysticism, 326.

${ }^{57}$ Jeanne Guyon, Experiencing the Depths of Jesus Christ. trans. Gene Edwards (Sargent, GA: the Seedsowers Press, 1975), 93-97. Gene Edwards titled this book as such for this edition, but the true title of Mme Guyon's original work was Moyen court et très facile pour l'oraison que tous peuvent pratiquer très aisément. I will use the abbreviated French title, Moyen court, in the text to indicate this
} 
to his chosen ones). The individual is indifferent to the activity going on within himself; in fact, they have very little to do with it since the drawing of the soul is not affected by prayer. According to Underhill, in true Quietist mystics, "their love and enthusiasm will not let them do that [be indifferent to the movement of their soul towards God]." ${ }^{58}$ It is this overriding emphasis of holy indifference which sets Mme Guyon apart from Molinos, as his journey to the state of Pure Love is governed by a purposeful choice of the individual to set out on this journey to begin with. Molinos says in proposition 2 in the Guide Spirituale that, "by not speaking nor desiring, and not thinking, she [the soul] arrives at the true and perfect mystical silence where in God speaks with the soul, communicates himself to it...." ${ }^{59}$ For Molinos, the action of the Quietist was in doing nothing at all: by not speaking and by clearing the mind of thoughts and desires. This does not display a passive indifference to activity, but rather a calculated attempt to bring about the condition of union with God. This position seems to be confirmed by the Blessed John Ruysbroeck (1293-1381) who said of the Quietist state that "the possession of God demands and supposes active love. He who thinks or feels otherwise is deceived." ${ }^{60}$ Mme Guyon's love is not active, and she is not making any active decisions about the movement of her soul to God; union is for her, rather, in God's hands alone.

work. Unless otherwise stated any quotes are, however, still from the edition translated by Gene Edwards.

${ }^{58}$ Mysticism, 326.

${ }^{59}$ Molinos, The Spiritual Guide, prop. 4.

${ }^{60}$ Taken from Mysticism, p. 325. Quoted by Underhill from Ruysbroeck's De Calculo, cap. Ix. 
When the Council of Issy met and overlooked this discrepancy of "holy indifference," only two reasons could have been imputed; either they did not fully understand the accusations against Molinos by the Inquisition of Rome in 1694 , or they intentionally chose to overlook this major contrariety. All that mattered was that she was condemned in order to lure Fénelon back to the accepted Church doctrine and away from Mme Guyon's influence. This fact is even more clear when it is considered that, for their final meeting in February 1695 the three ecclesiastics invited Fénelon to participate in their discussion. Fénelon did, in fact, attend this conference, and did sign the thirty-four propositions against the doctrine of Mme Guyon, no doubt influenced by the presence of his close friends and teachers: Fénelon then approached Mme Guyon with the suggestion that it was best for her to submit to the Council and to forgo further public exhibition of her doctrine. In accordance with this, Mme Guyon signed her first submission to the Council of Issy on April 15, 1695, and withdrew into the Visitation Convent at Meaux to be under the protection of Bossuet. In May, Bossuet sent a letter to his friend Pierre de La Broue, Bishop of Mirepoix, stating, "She is ready to submit to our ordinance and to the condemnation of her books... I am content to forbid her to write or dogmatize or to circulate her books. There is no sign of disobedience." ${ }^{61}$ The punishment suggested by Bossuet, that Madame Guyon simply be forbidden from writing or publically professing her beliefs, seems rather moderate considering that throughout Catholic Europe in the late seventeenth century persons associated 
with Molinos were being sentenced to life imprisonment. ${ }^{62}$ If she was a Molinosist as the Articles of Issy had asserted, wouldn't a more Molinosist punishment be appropriate for her? Possibly Bossuet could not bring himself to condemn a woman to prison whom he had truly condemned for reason of her self-sanctification, a lesser and more questionable heresy; this position will be discussed at length in future chapters.

Immediately after the Council of Issy, when the sky seemed once again to clear and resume its cheery blue, Bossuet postponed his disputation with Protestantism in order to write a definitive essay on prayer. The resulting Sur les États d'Oraison (On the States of Prayer) was an attempt to describe theologically acceptable methods of prayer, and could be seen as a direct response to Mme Guyon's Moyen court. This celebrated treatise was the true initial impetus for the Fénelon/Bossuet debates which followed. Bossuet actively asserts his disgust for inner prayer in a way which some historians have seen as a response for his aversion for Mme Guyon. E.K. Sanders describes in her biography of Bossuet that:

Among the motives that enraged him in this new enterprise must be counted his disgust and irritation at the astounding assertions of Madame Guyon: in his eyes she was both ignorant and crazy.... His attitude towards her differed essentially from that of his two colleagues [during the Council of Issy], who seem to have remained detached and undisturbed throughout their examination, and this difference did not escape the observation of Fénelon.... The truth was so true to him [Bossuet], and the hallucinations of the prophetess were so obviously

\footnotetext{
${ }^{62}$ Molinos himself died in a Roman prison in 1696 after spending eleven years in the same cell. Other persons convicted of Quietism (mostly in Spain and in Rome) where also imprisoned until their deaths. A description of the persecution of Molinos and his followers in Italy and Spain is given in the introduction to his Spiritual Guide written by the work's unnamed translator and editor.
} 
false, that the thought of the credence that had won her popularity drove him to frenzy. ${ }^{63}$

Sander's assertions in this passage regarding the extreme dislike of Bossuet for Mme Guyon will be explored in detail in upcoming chapters; what is crucial here, though, is that Bossuet simply could not withhold his anger for Mme Guyon after her initial submission and condemned her even after the Articles of Issy were published. Fénelon, however, managed with incredible speed to lunge fatefully into the developing controversy. Despite his participation in the conference at Issy, he was still not convinced that Mme Guyon was guilty of any heresy. In a race to the press, Fénelon published his l'Explication des maximes des saints in the spring of 1697 , an essay justifying the inner way taught by Mme Guyon by comparing it to previous Catholic mystics, only forty days before Bossuet's respected account on the various states of Catholic prayer, États d'Oraison, was released. Taken aback by the popular reception of the Maximes over his own work, Bossuet responded by publishing the acclaimed Relation sur le Quiétisme. The damaging literary period of the "Quietist Controversy" had begun.

The Relation sur le Quiétisme, composed by Bossuet as an acrimonious response to the immensely popular Maximes of Fénelon, was published in early 1698. This lengthy and well-organized text presents the entire controversy as

${ }^{63}$ Reynolds, 289. 
Bossuet himself viewed it, and has been called a "brilliant piece of polemic" by his biographers. ${ }^{64}$ This piece is valuable for the researcher because it presents a step-by-step account of Bossuet's main arguments against Mme Guyon, as well as a surprisingly detailed chronology of events which lead Bossuet to these conclusions. What becomes apparent in this work is that, as feminist historian François Mallet-Joris is enthusiastic to point out, it is directly written with the intent of absolving Bossuet's guilt (and astonishment) over losing Fénelon to the hands of Mme Guyon. ${ }^{65}$ The Relation is not meant as a essay further condemning Mme Guyon, for by the time it was written she was tucked safely away in the Bastille. In this work, Mme Guyon is a foul figure whose ominous presence ruined a gifted Church man, and this is the difficult point which Bossuet is struggling to accept and to explain.

The Relation is an excellent source in support of the assertion that Bossuet had a personal dislike for Mme Guyon, and was only employing the Quietism of Molinos in order to legitimate his feelings about her. As I have demonstrated in the above discussion, the accusation of Molinosism was an afterthought: it was not Bossuet's original conclusion about Mme Guyon, but was required in order to satisfy a specific goal. Having established this, I have alluded to the fact that Bossuet disliked her personally. He was shocked by her claims of a superabundance of God's grace; he was astounded at her working of

\footnotetext{
${ }^{64}$ Reynolds, 247.

65 According to Mallet-Joris, the real emphasis of the argument between Bossuet and Fénelon was over their own relationship with each other - man with man. Mme Guyon just happened to spark this confrontation, but she was not the center of the controversy. See Jeanne Guyon, chapter ix.
} 
miracles; he was skeptical about her self-assigned role as sole prophetess of God. Overall, Bossuet makes two interlaced conclusions about Mme Guyon: she thought of herself foremost as a living saint, and on top of this, she considered herself to be the sole bride of Christ, the woman of the apocalypse, as described in Chapter 12 of the Book of Revelation. These accusations, so well-explained in the Relation, will become the basis for examining how Mme Guyon thought of herself and how she thus justified this belief through her writings and actions.

Despite the fact that the first chapter of the Relation promises to show that Mme Guyon was a second Molinos, this allegation is never examined in detail until a later chapter on the Council of Issy, where it is passed over briefly. Bossuet dedicates the entire second chapter to describing Mme Guyon, her doctrine, and his conversations with her; Molinos is not mentioned in this discussion. He was hesitant to meet with her initially, he relates, because it was not a "divine vocation (vocation divine).." ${ }^{\prime 66}$ Instead, Bossuet was affected by her appearance of humility in asking for his advice about her writings:

This time, $I$ intended to enter into this exam, which one had so often repeated to me that God wanted, and that Mme Guyon only wanted to be taught by a bishop in whom she had confidence. I could not refuse her the instruction she had asked for with such humility, to which in the end I surrendered. ${ }^{67}$

Overcome with her charismatic request, Bossuet gave in to Mme Guyon's request reluctantly; after all, "God wanted it." ${ }^{68}$

\footnotetext{
${ }^{66}$ Relation, 1104.

${ }^{67}$ Relation, 1104.

${ }^{68}$ Relation, 1104.
} 
What follows in Bossuet's Relation is a cutting tale of the astounding claims of Mme Guyon which were either lifted from her own works, including her Vie, or were told to him during conversation. He describes her state of having a superabundance of God's divine grace (as discussed above), which he writes down with disgust: "one sees that it is useless to examine this strange communication." ${ }^{69}$ Calling her facetiously a "communicator of God's graces (communicatrice des grâces)," Bossuet continues by saying that because of this function she proclaims herself, "a prophetess and a worker of miracles." ${ }^{70}$ Commenting further, Bossuet says that:

In her Vie she speaks of herself in this way: Here is a new marvel, so above and so stronger than other men, the eminence of perfection that makes one look at a neighbor with the most tender condescension, ... she flatters by these superb apologies that in hidden complaisance makes her look weak with pride,...

According to this passage, Mme Guyon sees herself above others, a virtual saint who is without fault. To Bossuet, she assumes the appearance of holiness, humility, and prognostication, all the while asserting her own greatness over those who surround her. Mme Guyon maintains selflessness, but really practices careful selfishness. Bossuet further expresses this opinion when he writes:

In all the pages of this Vie she gets carried away so that they say: 'Oh, no one should speak to me anymore of humility. Virtues are no longer for me. No, my God, they are not for me anymore, nor perfection, nor

\footnotetext{
${ }^{69}$ Relation, 1108. By using the term "communication," Bossuet is referring to the manner in which Mme Guyon passed the abundance of God's grace from herself to those who were near her. Mme Guyon uses similar terminology in her own writing, thus classifying herself as one who receives the Word of God and who is able, then, to pass this Word on to others (as a communicatrice).

${ }^{70}$ Relation, 1108.

71 Relation, 1156-1157.
} 
holiness.' Everywhere in her Vie the virtuous manners are the imperfect manners: the virtue of humility is a feinted humility.... ${ }^{72}$

She is, or sees herself as a prophetess, a saint above other saints. Bossuet proclaims this further by saying:

Mme Guyon asserted that by a state of apostolic destiny, of which she was clothed and where souls of a certain state [God's chosen souls] were elevated, she was able to see into the bottom of souls. By this, she received miraculous authority given to her by God on persons and on their souls. ${ }^{73}$

Bossuet sees Mme Guyon, as this passage testifies, as believing she was Godlike. Similar to Christ, she had the ability to see into the souls of those around her, and like him, she was able to make judgement upon these souls. This power, although attained from God, was not shared by others on earth. The reason for this, Bossuet believes, was that she was not just a living saint. Despite the fact that she was elevated by God above all men on earth, Bossuet also claims that she places herself above the saints and apostles in heaven by presenting herself as the woman of the apocalypse.

In what is perhaps the most intriguing argument presented by Bossuet against Mme Guyon, he presents several lengthy points describing her position as bride of Christ - not just any bride of Christ, however, as in the traditional mystical sense - but the bride of Christ as described in the Book of Revelation. This woman, who as spouse of Christ is struggling to deliver his child, is seen as above other saints because of her status as wife of Christ. In the Relation,

\footnotetext{
72 Relation, 1158.

${ }^{73}$ Relation, 1109.
} 
Bossuet concludes that Mme Guyon undoubtedly saw herself as this woman, from which she drew endless authority and power. Leading up to his discussion, he warns the reader of the impending absurdity of what he is about to say:

It is necessary to warn the faithful against a seduction that continues: a woman who is capable of deceiving souls by such illusions must be exposed, especially when she finds admirers and defenders who are great advantages to her.... I confess that here is a work of darkness which one has desired to keep hidden, waiting for three years in impenetrable silence which perhaps would have lasted longer had it not been for an abuse of my discretion [referring to the Maximes of Fénelon].... ${ }^{74}$

As the discussion continues, Bossuet presents evidence drawn from Mme Guyon's controversial biblical commentary called Sur l'Apocalypse (translated in English as Christ our Revelation). Combining this reference with things she revealed to him during their conversations together, Bossuet presents the picture of Mme Guyon as this very woman. He writes:

'One night," she tells God, "I was forcefully awakened, and you showed me to myself as the face of the woman of the apocalypse. You showed me this mystery'... She sees herself, and sees the sun of Justice that surrounded her, and all the divine virtues which made a crown above her head. 'She was full of his fruit, it was the espirt, Lord,' she said, 'that you wanted me to communicate to all my children. The demon throws a stream of slander against me. The earth would swallow this demon, and it would fall little by little. I would have millions of children. ${ }^{\prime 75}$

Bossuet gives further explanation and examples of Mme Guyon's claim to be the woman of the apocalypse, as shown to her in the vision by God. This absurd affirmation, he says, was meant to scare those who were persecuting her (including, foremost, Bossuet himself). He says, "I reached the place lin her

74 Relation, 1107. 
writings] where she predicted the next reign of the Holy Spirit over all the earth. This period had to be proceeded by the terrible persecution of prayer." ${ }^{76}$ This threat to Bossuet and others, perfectly manifest by Mme Guyon, must have been incredible for a respected, and learned, bishop. He writes, almost angrily, that "There is proof that she tells her friends that there will be a marvelous future.... Without dwelling on her free-for-all predictions of truths and falsities which she presents unceasingly, I will only point out that she confirms this in her vain visions of the pregnant woman of the apocalypse...." ${ }^{77}$ And a few sentence later, the bishop of Meaux is almost desperate to prove his point, "I know how I will explain how she presents herself as the most important person [la première]. ${ }^{\prime 78}$ After this, he proceeds to give a laundrylist of examples in an effort to prove to his reader that Mme Guyon saw herself as a saint, and as the only bride of Christ. By the end of the Relation, there is no doubt in Bossuet's mind that these assertions were true, and that this was why she should primarily be condemned. In the conclusion, Bossuet calls her the "mysterious woman of the apocalypse," and warns that, "this woman's work is not finished." 79

To accuse Mme Guyon of teaching Molinosism, the members of the Council of Issy headed by Bossuet were making sure that she would be universally condemned. The previous censuring of all Quietist-related teachings

\footnotetext{
${ }^{75}$ Relation, 1109.

${ }^{76}$ Relation, 1109.

${ }^{77}$ Relation, $1110-1111$.

78 Relation, 1111.
} 
in the late $1680^{\prime} \mathrm{s}$ and $1690^{\prime} \mathrm{s}$ by papal authority meant that everyone associated with this trend was a heretic. Bossuet, suspecting the Mme Guyon was selfcanonizing herself in an incredibly bold way, and instinctively disliking her for this, could not have persecuted her on such a seemingly frivolous charge. It would be impossible to prove whether or not her assertions of holiness were true. Moreover, her strange charismatic popularity seemed to be gaining her a larger number of highly influential supporters each day. The aging Bossuet, who had gathered his share of enemies in the likes of Jansenists and many members of the royal family, perhaps felt that it was better to hedge his condemnation against Jeanne Guyon with something that even his enemies would support. This is why, in 1693-1694, he did not actively pursue her, and did not accuse her of being a Quietist. Perhaps at this time Bossuet was hoping, on some level, to persuade her to amend her ways and to stop acting as though she was the sanctified woman of the apocalypse (who had, thus, greater authority than the Church itself). Her persistence, combined with blatant disregard for his suggestions, reluctantly forced Bossuet into continuing to examine her doctrine. This resulted in the formation of the Council of Issy which ultimately convicted her of Molinosism, after all, this Council never would have been formed without the unending persistence of Mme Guyon that her works be further judged. Had she not insisted on enlisting other prestigious Churchmen to consider her works, with the hope that they would be easily persuaded (and awed) by and of her sanctity, Bossuet may never have become involved with her. Mme Guyon is 
responsible for her own condemnation, due in large part to the fact that persecution was a central theme of her doctrine of inner prayer. The critical point presented in this chapter is that Mme Guyon would not stop until she was accepted as a living saint, and it was this ambition which ultimately led to her imprisonment. 


\title{
Chapter 2 \\ A Living Saint and the Queen of Heaven
}

\author{
"They [Saints] are signs of hope, signs of the kingdom - \\ its presence, and its present and future possibility. \\ They are symbols which have authority. ${ }^{80}$ \\ John Garvey, Meditations on Saints
}

"Among so great a number of good souls, on whom our Lord wrought much by me, some were given me only as plants to cultivate. I knew their state,

but had not that near connection with, or authority over them, which I had over others." ${ }^{81}$ Jeanne Guyon

Jacques-Bénigne Bossuet was irritated with Mme Guyon because of her claim of living sainthood. He relentlessly attempted to expose her "absurd" declarations, and when this personal attack was shown to be unsuccessful, Bossuet resorted to accusing her of an accepted heresy. Mme Guyon was more than anxious to introduce herself to Bossuet in order to convince such a powerful figure of her greatness. It was she who probably initiated their first contact in 1693, and it was certainly she who would not let the matter rest in June of 1694. Mme Guyon was eager to gain his support, and thus capture a powerful ally. The question which arises then is, why would she go to such great lengths to expose herself to open and scrutinizing examination repeatedly, especially when things were not exactly in her favor? Why would she not honor her word in May 1694 and submit to the Church, of which she claimed to still

\footnotetext{
80 John Garvey, Meditations on Saints (Chicago: Thomas More Press, 1975), 108.

${ }^{81}$ Jeanne Guyon, An Autobiography: Madame Guyon, trans. Gene Edwards (Chicago: Moody Press, 1970), 309. For the purposes of this thesis, this work will be referred to in the footnotes and the text as simply the Vie (referring to the original title, La vie de Madame Guyon).
} 
be a faithful member? Something else was driving Mme Guyon along in her quest, something which was so attractive and tempting a goal that she could not restrain her actions. The answer, which has been completely disregarded by researchers since, was clearly presented by Bossuet; Mme Guyon was (in her mind) a living saint. In order to understand this assertion further, it is necessary to spend some time describing the various attributes, rewards, styles, and symbols of saints within the Catholic Church. Why are they so powerful, and what were they doing which ultimately resulted in their canonization? A final section of this chapter will examine the highest (if fictional) saint of all - the true bride of Christ, as seen in the enigmatic Book of Revelation. Such a study will assist the remaining chapters, where I present evidence that Mme Guyon assumed sainthood, and wife-hood, in order to become an immediate member of heaven's royal family.

Canonization has always been considered the ultimate reward for those who chose to dedicate themselves fully to the earthly service of Christ. These saints become catapulted by a single decree of the pope into celebrities for the ages. The image of the saint is one which is taught to Catholics from their initial contact with the church. The saints are pure and holy individuals, esteemed and celebrated as crucial members of the Catholic experience. Believers are told endless legends about male and female saints throughout the ages which are supposed to inspire them to similar actions. Caroline Williams writes in her 
Saints: Their Cults and Their Origins, that a communion of saints "enabled the faithful to focus and channel their own religious energies and aspirations. They were more immediate, more accessible. ${ }^{\prime 82}$ The saints' relics healed the sick, predicted the future, and protected followers from harm. Their burial shrines drew thousands each year eager to worship and pray. Hagiographies were told and retold throughout the ages making their subjects immortal in the eyes of their followers. Each of the saints even had their own special day of the year in the Catholic calender on which they were, and are, honored and remembered. Clearly, to be among this heavenly group was something that most Christians, especially in societies that were strongly religious, aspired to.

During the Early Modern period in Europe, and especially following the Reformation, the Catholic Church placed particular emphasis on the cult of saints. C.C. Martindale, a great contemporary hagiographer, says that the Counter-Reformation placed great emphasis on saints in order to add a personal dimension to the ailing Catholic religion. France in particular, he says, was known for its outstanding number of saints during this period. ${ }^{83}$ Many individuals in the Church sought to revive the perhaps fading concept of the saint in order to inspire a personal contact with Church traditions and hierarchy. In many ways, the ideal of this perfect Christian was given new life in order to provide the emotional bond that many felt was missing in the Catholic ceremony, an aspect which was endlessly attacked by Protestants in the late

${ }^{82}$ Caroline Williams, Saints: Their Cults and Their Origins (New York: St. Martin's Press, 1980), 8. 
sixteenth century. As Caroline Williams's history of saints concurs, the Catholic veneration of saints during the Reformation period was brutally castigated by Calvinists who had a mistrust for the veneration of the Almighty "through gilded statues and graven images. ${ }^{84}$ The Counter-Reformation attempted to reverse this discrimination by installing the Glorious Company as more permanent fixtures in Catholic belief and practice. In doing so, devotional paintings and sculpture of the period became increasingly flamboyant. Hagiography flourished throughout the seventeenth century, inspired tremendously by the attention given to the cult of saints by the various popes.

The attention of Rome on the matter of saints was apparent best in 1634, when a rigid procedure for official canonization was finally established by Pope Urban VIII (1623-1644) in the Apostolic Constitution Coelestic Hierusalem Cives. The initial concern of the Church authorities was confirming exactly what the title of saint represented. According to the standards established by the Coelestic, a saint was "a person of holy character who is venerated as an example of religious and personal excellence for having a life 'in imitation of Christ. ${ }^{\prime \prime 85}$ Almost immediately following this declaration, the number of applications for canonization increased dramatically, a pattern which would continue well into the eighteenth century. The path to canonization, however, took many years, as the cult of the individual saint had to be fostered by their

${ }^{83}$ C.C. Martindale, The Queen's Daughters: A Study of Women Saints (New York: Sheed and Ward, 1951), introduction, 145-146.

${ }^{84}$ Williams, 8.

${ }^{-85}$ Williams, 8. 
followers through the spreading of their ideas, the publishing or republishing of their works, and by encouraging a high level of enthusiasm for their relics and miracles. Several major figures in Catholic history were officially recognized during this period. François de Sales was swiftly canonized in 1665, after having died only forty-three years earlier. His spiritual companion, St. JeanneFrançois de Chantal, also became highly admired for her successful Order of the Visitation, was beatified in 1751 and received the title of "saint" in 1767. The cult of Vincent de Paul, who founded the inspiring Sisters of Charity in 1625, gained enormous support for their patron in the late 1600's and early 1700's, resulting in his canonization in 1737 . Catherine of Genoa, who shall be shown as a major influence on Mme Guyon, was canonized in 1737 . The mystic Angela of Foligno was pronounced "Blessed" in 1693. The beloved French Dominican prioress Margaret of Savoy was beatified in 1669 . While the list of persons canonized during this period is extensive, the main point is that the Counter-Reformation was a period that needed saints in order to reconfirm the importance of the individual to the Catholic Church. The production of an official ritual of canonization, with its glamour, its influence, and its prestige, focused the spotlight of believers onto some of the very best persons in the religion, which in turn inspired them to reach similar heights.

The greatest problem which confronts those wishing to study the saints (or to canonize them) is that of qualification: just what does it take to become a saint, or more precisely, what's that timeless saintly formula? With over 25,000 
confirmed saints, the task of finding the just-right equation seems dauntless. Theologian John Garvey tackled this question head-on in the Meditation on Saints when he asked: "What is a saint? The question is part of the answer. There is no one answer. Or rather, there are as many answers as there are human beings.... Attempts at some final definition of sanctity will be sabotaged all along the way by saints who simply won't fit." ${ }^{86}$ Admired saint-watcher Phyllis McGinley had a similar concern when she wrote, throwing her hands up in desperation, "At once so alike and so diverse are the personalities of my heroes that no pope or bishop or even fellow saint can say dogmatically, 'Do this, renounce that, and you will be called blessed. ${ }^{\prime \prime}{ }^{87}$ Despite this assertion, the saints do seem to have qualities which unite them, including their power and influence during and after their lives, the lack of any moderation in their actions, and an usually difficult mortal struggle, such as excessive illness or persecution.

The saints who I will use in the general discussion which follows are those who Mme Guyon was probably most familiar with, either because she quotes from them directly, or because their examples were used in works she had read. Other saints I will refer to represent some of the major figures in the late seventeenth century whom Mme Guyon may have been at least partially familiar with. The impression I am seeking to give in this section is that the symbol of the saint was ever-present in the French society of the time, and that

\footnotetext{
86 Garvey, 18.

87 Phyllis McGinley, Saint-Watching (New York: Viking Press, 1969), 17.
} 
Mme Guyon, as a Catholic and as a former convent student, would have been acquainted with their actions. In the emulation of saints, Mme Guyon seems to be closely aligning herself to female saints in that she assumes a more caring, emotional nature. According to Sandra Wawrytko, female mystics show preference for unity, described as "all-in-one-ness with no distinction between the mystic and the source," body sense where the physical experience is the mystical stimulus, and light, or the "receptiveity to externals leading to an openness to the mystical experience. ${ }^{\prime 88}$ All of these traits are visible in the mystical descriptions of Mme Guyon. She aligns herself closely with St. Theresa of Avila, St. Jeanne de Chantal, Mary Magdeline, St. Catherine of Siena, and the Blessed Angela of Foligno, and she refers to these ladies directly and indirectly several times in the Vie. For this reason, these figures will constitute the main saints discussed in this chapter. As well, I have chosen to include the popular male mystics St. François de Sales, St. John of the Cross, and St. Francis of Assisi, as well as some of the early Catholic women saints whom Mme Guyon expressed familiarity with. The entire goal of this section is to convey a sense of what Mme Guyon would have considered to be saintly actions, because it would then follow that her own behavior would resemble those saints whom she most admired.

\footnotetext{
${ }^{88}$ Sandra Wawrytko, "The Feminine Mode of Mysticism" in Mysticism and The Mystical Experience, Donald Bishop, ed. (Toronto: Associated University Presses, 1995), 219. 
The figure of the saint in the Catholic mind is of an individual with power and influence, both before and after death. During life, the saints are individuals who are overcome with the desire to serve God, and who will go to any means to do so. For this reason, they often have had a tremendous influence on other men and women. C.C. Martindale describes this power as:

colossal influence. They did not argue: 'Because God loves mankind, therefore I ought to do so too'; but, having in them 'that mind which also was like Christ Jesus'. Having in them a heart like to His heart, they forthrightly love; they love intensely; they serve to the ultimate limit of self-sacrifice and beyond it. ${ }^{89}$

Due to this ability to push themselves to the limits in order to show their love of God, the saints were often important forces in society. Catherine of Siena used her prestige gained from working among the poor of her home town to persuade Pope Gregory XI to abandon Avignon and return to Rome. Later, she tried desperately to heal the great schism of the West, and used the admiration of the public for her charitable works to unite Italy around Pope Urban VI. Likewise, St. François de Sales used the tremendous popularity he had gained as bishop of Geneva to found, with St. Jeanne de Chantal, the congregation of the Visitation of the Virgin Mary. Despite initial opposition, the Order gained popularity among widowed and disadvantaged ladies, and the fame and influence of de Sales and Chantal spread throughout Europe. Before her death, St. Jeanne was being called to all ends of France by wealthy nobles who sought her advice and spiritual wisdom. As for St. François de Sales, his influence over the whole of

${ }^{89}$ C.C. Martindale, What are Saints?: Fifteen Chapters in Sanctity (Freeport, NY: Books for Libraries Press, Inc., 1968), 18. 
France was tremendous, and his book Introduction á la vie dévote (Introduction to the Devout Life) is considered a theological masterpiece. The ability of these saints to draw people to them can not be questioned, and by their actions, they were able to influence politicians, nobles, and Church leaders. Their lives are examples of persons with power, derived from God and meant to serve God, but power in this life nonetheless. This influence did not end with their deaths, as the cult of saints testifies. C.C. Martindale says of them, "People by the million today are trying to manage their lives, even, to change their lives, to ennoble their lives, because of some man or woman, boy or girl, who long ago earned the title 'saint'. ${ }^{\prime 90}$ The saints are the members of the Church which have achieved immortality, who are the closest links between man and Jesus, and who are perhaps the "only real Christians." 91

Gaining such power often required the saint, or future saint, to embrace a lack of moderation in their actions. Many persons could practice charity in a modest form, perhaps by tending their sick family members or by donating money to the local convent. Those who became saints, however, went beyond this. Some, like St. Francis of Assisi, gave up all material possessions in order to live in utter poverty. Many times those future saints often would do daring, immoderate, things in order to gain the attention of spectators. The Blessed Angela of Foligno twisted and turned on the ground outside of the Church of the

\footnotetext{
90 Martindale, 15.

91 Garvey, 20.
} 
Holy Trinity in Foligno yelling, 'Love is gone, Why? Why? Why?" ${ }^{92}$ Despite the horror of those around her, she managed to gain a widespread reputation because of her excessive behavior. Usually, as these two examples show, the individual was galvanized by the spirit of charity in the manner taught by Jesus in the New Testament. This charity, however, was an excessive charity; instead of opening one Order or establishing one hospital, these future saints like St. Teresa of Avila and St. John of the Cross sought to establish several institutions throughout Europe, and the world if possible. These saints are remembered for all that they accomplished because it surpassed, sometimes by leagues, what others around them were doing. St. François de Sales personified this state of constant action without rest by saying, "For seven or eight days I have not even been able to give a thought to myself. I can only get a superficial glimpse of myself." ${ }^{93}$ Because they engaged in constant activity, unceasingly spreading the Word of God, or meditating on its meaning, those who became saints were working above and beyond the normal call of God to humanity. Phyllis McGinley explicated this situation best when she said, "The saints differ from us in their exuberance, the excess of our human talents. Moderation is not their secret. It is in the wildness of their dreams, the desperate vitality of their ambitions, that they stand apart from ordinary men of good will." ${ }^{94}$ Those who

\footnotetext{
92 Angela of Foligno, The Complete Works of Angela of Foligno, trans. Paul LaChance (New York: Paulist Press, 1993), 19.

${ }_{93}$ Quote taken from Michael de La Bedoyere, François de Sales (New York: Harper \& Brothers, 1960), 143.

${ }^{94}$ McGinley, 19.
} 
became saints and gained recognition from the Church did things above the level of the average individual, and often did so to an extreme level.

One final ingredient which reigns over the lives of the saints is that of an overwhelming sense of humanity, present in the form of extremely difficult mortal struggles. The first example of this is physical torture by illness. Their wounds were laid open to be seen, their physical bodies tortured either by their own will (such as those who purposefully ate little) or by a raging disease. IIIness, while certainly not a widespread aspect of sanctity, was a major component for many who were eventually canonized. Mystics in particular, including Hildegard of Bingen, Angela of Foligno, Catherine of Siena, Catherine of Genoa, and even Teresa of Avila were particularly susceptible to long-term illnesses. As Donald Weinstein and Rudolph Bell have demonstrated, infirmity, especially in the life of the female mystic, was a central factor in reputation for sanctity. ${ }^{95}$ In many cases, as pointed out by Caroline Bynum in Holy Feast and Holy Fast, these bouts with various illnesses (most, as Bynum asserts, being caused by an eating disorder) were eventually considered desirable by the saint: "The heroic embracing of sickness characterized only saints." ${ }^{96}$

This same overwhelming humanity which afflicted their bodies likewise caused the persecution of many of them. There are endless examples of saints who were at first condemned by the Church for some reason, only to be

\footnotetext{
${ }^{55}$ Donald Weinstein and Rudolph Bell, Saints and Society: The Two Worlds of Western Christendom, 1000-1700 (Chicago: University of Chicago Press, 1982), 234-235.

${ }_{96}$ Caroline Bynum, Holy Feast and Holy Fast: The Religious Significance of Food to Medieval Women (Berkeley: University of California Press, 1987), 200.
} 
vindicated by the hand of God later. The finest instance of this is the life of St. John of the Cross, who was arrested by the principal of Castille for refusing to return to his friary in Medina in 1577 . St. John was carried off and placed in a tiny cell next to the Calced Carmelite priory in Toledo. According to the definitive work on saints by Alban Butler, St. John was "bloodily beaten - he bore the marks to his dying day - by order of Jerome Tostado, vicar general of the Carmelites in Spain and a consular of the Inquisition." ${ }^{97}$ And who can forget the skepticism of the Catholic authorities when a young St. Francis of Assisi began his Order preaching the absolute poverty of its participants. Every day was a battle with the Church for Francis, who sought to purge this corrupt institution of its greed, and met a healthy amount of resistance in the process.

The persecution of saints is also well-known through the best-loved lives of the popular virgin martyrs of the early Church. ${ }^{98}$ Heroines such as St. Catherine of Alexandria, St. Elizabeth of Hungary, and St. Barbara were persecuted by pagans and Catholics alike. St. Marina had to live her life as a male in a Catholic monastery because she could not bear to live in the outside world where she was not able to join a convent because of her poverty. St. Agnes was accursed by fellow Christians because she refused to marry, so ardent she was to save her virginity for Jesus Christ. In each of these cases, for whatever

\footnotetext{
97 Alban Butler, Lives of the Saints, ed. Michael Walsh (San Francisco: Harper Collins, 1991), 418. This work was originally published in 1756-1759 in four volumes, and is considered "one of the most influential works of piety produced within the English Catholic community." p. vii.

98 An outstanding anthology of these timeless Catholic saints can be found in Brigitte Cazelles's the Lady as Saint: A Collection of French Hagiographic Romanced of the Thirteenth Century (Philadelphia: University of Pennsylvania Press, 1991).
} 
reason, the saints were persecuted for their beliefs and actions. C.C. Martindale says, "After all, they had to win their battles, and were often wounded in winning them. Not everything in the saints' lives will be equally attractive." ${ }^{99}$ John Garvey comments that "the saints often suffered at the hands of the Church.... Christianity may not always work in ways that make our lives comfortable. ${ }^{\prime 100}$ The persecution of the individual is a central theme in many instances of canonization, especially when this criticism comes preliminarily from the Church itself. Nonetheless, this persecution -- physical, mental or both -- was a very mortal aspect of the saint's life, and it remains to be seen if one who has never fought similar obstacles will achieve a similar level of sanctity.

Among the popular mystics there is also a sense of personal struggle and perseverance, which allowed them to relate to the reader of their works on a more personal level. In her autobiography, St. Teresa of Avila often describes her own many faults and how she is motivated out of love for God to overcome them. Repeatedly, she gives examples of her own inclination towards sin and self-love:

I used to try to keep his feast with the greatest possible solemnity; but, though my intentions were good, I would always observe it with more vanity than spirituality, for I always wanted things to be done very meticulously and well. I have this unfortunate characteristic that, if the Lord gave me grace to do anything good, the way I did it was full of imperfections. ${ }^{101}$

And likewise:

\footnotetext{
${ }^{99}$ Martindale, xiii.

${ }^{100}$ Garvey, 96-97.

101 St. Teresa of Avila, The Autobiography of St. Teresa of Avila, trans. E. Allison Peers. (Garden City, NY: Image Books, 1960), 93.
} 
One of my faults was this: I knew very little of my officebook, and of what I ought to do in choir, and of how to behave simply because I was careless and absorbed in other vanities.... I was bad at singing... seeing that all the nuns except myself were making progress (for I myself was always a good-for-nothing) I would collect their mantles when they left the choir. I felt that by doing this I was serving angels who were praising God there, until - I do not know how - they came to hear of it, which made me not a little ashamed.... O my Lord, how ashamed I am at having to confess all this wickedness! ${ }^{102}$

In these passages St. Teresa presents herself as a real person - not as someone who is extraordinary or superior to other Christians - but as someone who has faults, and who continues to have vices and personal difficulties despite her achievement of unity with the Lord. She is genuinely human, able to identify with her readers and, more importantly, she is capable of drawing them into her world of the Prayer of the Quiet because she is showing them that she was and continues to be just like the ordinary person. A close, spiritual bond with Christ has not changed the fact that, like all other human beings, she cannot always be selfless, and indeed falls to temptations, such as vanity, like everyone else.

One other aspect of many saints' lives relating to the fact that they were human, and thus lived in and interacted with a human society, was that several had been married against their better judgement. This presents a problem for those wishing to travel along the traditional path to canonization since, as seen with the virgin martyrs, the Catholic Church has always heralded a doctrine of virginity and celibacy. Therefore, those saints who married were a special breed of individuals who succeeded in gaining their status by means which sought to

102 St. Teresa, Autobiography, 298-299. 
erase a lack of chastity. Elizabeth Whitehead studied the phenomenon of the married saint in her Saints for the Married, which led her to the inevitable conclusion that "everything, humanly speaking, is against the canonization of the married. ${ }^{\prime 103}$ Nevertheless, it does indeed happen. The Blessed Angela of Foligno was married and had several sons, and when they all died, she became a Franciscan tertiary. St. Catherine of Genoa was married to Julian Adorno at sixteen and after his death in 1471 she worked in the Genoan hospital they had established together until her death in 1507 . The great St. Jeanne de Chantal married the wealthy Baron de Chantal, with whom she had seven children. After her husband's death in 1601, St. Chantal sought a more holy life, and it was given to her in the person of St. François de Sales; together, they founded the Order of the Visitation, a convent for widows and ladies who could not stand the austerities of the older orders. St. Paula and St. Elizabeth of Hungary, who both enjoyed large cults in France and northern Europe, had been married as young women. Thus, to be married did not necessarily exclude someone from the Glorious Orders, although it did make the coveted title more difficult to obtain. The key, Selden Delany writes, is that the married person must practice the same virtues as those who are celibate:

For married people, as for Religious, life is fundamentally the same in its end as in the means by which that end is attained. For both, end and means, are alike union with God.... Though they do not take the vows, the Married are in no sense dispensed from the virtues of poverty, chastity, and obedience." ${ }^{104}$

\footnotetext{
${ }^{103}$ Elizabeth Whitehead, Saints for the Married (Liverpool: The Mercier Press Limited, 1949), vii.

${ }^{104}$ Selden Delany, Married Saints (Westminster, MD: The Newman Press, 1950), x.
} 
The difficulty of being married and still fulfilling the requirements of sanctity is further complicated by a mystical marriage with God: one has two husbands (or spouses) if they are married simultaneously to an earthly spouse and the heavenly one.

The mystical marriage has been popular since St. Bernard of Clairvaux's influential reinterpretation of the "Song of Songs," which transformed the "bride" from the institution of the Church into the individual, with the groom in both instances being Jesus Christ. Countless saints and mystics in the Catholic Church have considered themselves the brides of Christ, and it would be difficult to imagine them without this trait. The Blessed Angela of Foligno married herself to Christ in a secret ceremony, and would have visions of her husband speaking to her as his wife: "Daughter and my sweet bride," he called to her, "I love you more than any other women in the valley of Spoleto... My Beloved, my bride, love me, for your whole life. ${ }^{\prime 105}$ St. Catherine of Genoa and St. Catherine of Siena both experienced a similar mystical marriage to Christ, the latter marrying herself to Jesus in an elaborate ceremony at fifteen. ${ }^{106}$ St. Umiltà of Faenza describes in her Sermons that Jesus was her "sweet lover," and begged Jesus as her husband: "give yourself wholly to me, and don't hide yourself from me if

\footnotetext{
105 Angela of Foligno, Le livre de la Bienheureuse Soeur Angèle de Foligno, ed. and trans. Paul Doncoeur (Paris: Librairie de l'art catholique, 1926), par. 35.

${ }^{106}$ See St. Catherine of Siena, The Dialogue of the Seraphic Virgin Catherine of Siena, trans. Algar Thorold (Westminster, MD: Christian Classics, 1973).
} 
you want truly to console me." ${ }^{107}$ Similarly, the virgin martyrs of the Catholic Church went to extreme lengths to remain chaste so that their virginity could be saved for their future spouse-after-death. The immensely popular (if mythical) St. Catherine of Alexandria pled to Jesus before her murder by the pagan emperor of Rome, saying "I see Christ in His Heaven, calling me and inviting me To Join him on high. He is my Spouse, He is my friend. To Him I have given my heart. He is my husband and my Crown." 108

The imagery of the mortal individual being taken as the spouse of God was, and is, extremely prevalent in Catholicism, although in most cases the woman realized that she was not the only bride of Christ. ${ }^{109}$ After all, nuns were considered as the living brides of Christ, and the church itself was thought of a the spouse of God. Many women, not only saints, already sat at Jesus' side in heaven. This realization did not stop some from hoping, though, that they were the only lover of Christ. The Flemish Beguine Hadewicjh of Brabant said in her Sermons, "I have hated many great wonderful deeds and experiences, because I wished to belong to Love alone, and because I could not believe that any human creature loved him so passionately as I. $^{110}$ This realization that one was not the only bride to Christ may have been difficult for some to comprehend, but it

\footnotetext{
107 Umilta of Faenza, "Sermons," taken from Medieval Women's Visionary Literature, ed. Elizabeth Petroff (New York: Oxford University Press, 1986), sixth sermon, parts $1 \& 2$.

108 Cazelles, The Lady as Saint, 129.

109 I speak specifically of women here as the brides of Christ mainly because most women mystics used this specification. Some male mystics adopted a similar belief; however, they were not married to Christ but to the Virgin Mary. For example, St. Bernard of Clairvaux claims that he married the virgin Mary, and then assumed the name and role of Joseph.

${ }^{110}$ Hadewicjh of Brabant, Hadewicjh: the Complete Works, trans. Mother Columbia Hart (New York: Paulist Press, 1980), vision 11.
} 
inspired many mystics, nonetheless, to celebrate the other individuals who had achieved a similar position. Hadewicjh, whose name appears in several references to mysticism since the fourteenth century, expressed this feeling best when she wrote, "In this wonderful way I belong to God alone in pure love, and to my saint in love, and then to all the saints, each one according to his dignity, and to men according to what each one loved and also according to what he was and still is." ${ }^{111}$ The veneration of the saints, as well as the Virgin Mary, come second to the praise of Jesus, but nonetheless the Catholic mystics did not generally reject the cult of saints entirely as they sought heavenly status as Jesus' spouse.

A final word of relevance about saints is appropriate, and that is that saints rarely ever thought of themselves as saints. In other words, they did not have the self-admiration of being saints on earth: this quality would have reflected self-love, something that these sanctimonious individuals were trying to avoid. In Meditation on Saints, John Garvey discussed the importance of the saintly individuals during their lifetimes:

Through their dedication something of what they claimed to recognize showed itself in them, so much so that men and women who knew them, and others who came later, felt that they should be paid reverence. These people were seen to be living signs that the way they preached was real they had made it their own. The Word has taken on real flesh in the saints; they are living examples of the wisdom of Jesus' parables, people in whom the seed had grown, and flourishes. ${ }^{112}$

111 Petroff has a brief discussion about the influence of Hadewicjh in the introduction to chapter IV of Medieval Women's Visionary Literature; Hadewicjh, vision 11.

H12 Garvey, 34-35. 
Individuals who became saints were ones who could convince others (intentionally or otherwise) that their behavior was inspired by Jesus alone; they were, in effect, showing that by resembling Jesus they had been chosen as special by him. Despite the constant struggle between the will of the self and the will of God, the saints always managed to choose Jesus over themselves. As a result, they gained public attention, as pointed out by Garvey. However, the saints rarely thought of themselves as special, for this would destroy the delicate balance of denying self-will. Garvey points out that "it is important to remember that the saints never thought of themselves as saints - other Christians did that work." ${ }^{113}$ They could act like saints, but they could not think of themselves as such: to do so would disprove their sanctity.

To be the spouse of the Lord and member of the Glorious Order, one would have to assume saintly characteristics as much as possible: humility, charity, and other traits that have been discussed. In the Catholic Church, the mystical spouse of Christ was an encouraged and wide-spread phenomenon, as many who believed themselves to be spouses of God have been canonized and revered over the centuries. But, a spouse is different than a saint; just because Hildegard of Bingen or St. Teresa of Avila thought of themselves as brides of Jesus did not mean that they expected, or demanded, to be a part of the cult of saints. The status of spouse, which could only be fully realized after their own death, seems to have sufficed for them. As will be shown in later chapters, Mme Guyon knew this requirement, but chose to ignore it because she believed

113 Garvey, 79. 
herself above these other brides of Christ. Mme Guyon was not just a bride of Christ, sitting amongst the ranks of nuns, visionaries, and other persons - she was the bride of Christ, and thus had the right to advertise her position openly. In pursuit of union with God, the writings of such popular mystics as St. Teresa of Avila and St. François de Sales often reflect tenderness, kindness, and understanding, much in the manner used by Jesus to gather followers into his flock. Reading the Blessed Angela of Foligno or St. Catherine of Siena inspires one to invite Christ into one's soul in a similar manner due to the compassion and tender support offered by the author. Mystics such as these seemed to consider themselves missionaries for Jesus, and sought to provide emotional support for those who wished to know God in a deeper way. Their individual methods of convincing their readers that this Prayer of the Quiet, or mystical union, is highly beneficial and satisfying differs only slightly. All of these Catholic mystics expressed to their audience detailed descriptions of their own journey to God, as though they believed that the best teaching comes by example. As well, many mystics gave encouraging words to support the struggling actions of others who wished to achieve the same status. Despite the different methods and suggestions by these authors, each seems to hold the notion that union with God is achievable by anyone who wishes to do so. In the world of these Catholic mystics, God was capable of being the bridegroom to innumerable persons, each of whom was rewarded for perseverance and dedication by becoming his bride. 
St. Teresa of Avila would often support her readers in their journey to union with God by showing them that they could achieve this objective simply because it was nearly impossible for them to be more lowly than she: "I am, in short, a woman, and not even a good one, but wicked." ${ }^{114}$ St. Teresa's message to her readers was that if she could receive God's favor, than anyone could. She even invites them to speak personally with her, saying:

And so I say, if there are any persons (and there must be many) who have attained to the experience in prayer which the Lord has granted to this miserable woman, and who think that they have strayed from the path and wish to discuss these matter with me, the Lord will help his servant to present His truth. ${ }^{115}$

Thus, she is inviting, kind, and supportive, and sure that she is not the only one who is capable of union with God; on the contrary, she believes that those who are chosen for such an honor are quite numerous. As the example of St. Teresa attests, the Catholic mystic tended to be supportive of others in their journey to God. In many ways, they were holy mentors lending guidance to those sitting in front of them or reading a passage several centuries in the future. Many considered themselves teachers who wished to spread the good news of union with God, and certainly it would appear by the mystics presented above that they were not jealous or possessive of the Lord but wished to share him with as many as possible. St. Teresa, Angela of Foligno, and others seemed to gain pleasure by bringing spiritual children to God who could attain the same level as themselves. In their view, it seems, the

\footnotetext{
114 St. Teresa of Avila, Autobiography, 175.
}

-115 St. Teresa, Autobiography, 176. 
Lord could and did have many brides, and this heavenly polygamy has perfectly acceptable for the mystic who actually took joy and satisfaction in this fact.

Expanding this mold in the late seventeenth century, however, was Jeanne Guyon. While she struggled, in her writings and her actions, to emulate these same Catholic mystics and saints that I have used as examples throughout this chapter - St. Teresa of Avila, the Blessed Angela of Foligno, St. Catherine of Siena, St. Catherine of Genoa, St. François de Sales, St. Jeanne de Chantal - she became convinced that she was a living saint who stood above the other saints. Mme Guyon adopted, or claims in her writings to have adopted, the various attributes of saints I have described above, and she attempted, for a time, to be immodest about her saintly condition. In her Vie, she describes waiting and wishing for several years for those around her to just accept the her as the saint she was. This patience can be seen as stemming from that of saints like St. Teresa, who did not act as though they were special and who did not act as though they required any external recognition. The key distinction is that Mme Guyon reached a point where she could no longer wait for recognition, and I believe that this was one of the major factors inspiring her to write the autobiography. To Mme Guyon her chosen, elevated status was not achievable to her contemporaries because she, alone, was the special bride chosen by Christ. Others, of course, could act like saints, and possibly even be canonized, but they were never to reach the level she had attained. To Mme Guyon, her role as 'top saint,' and bride of Christ, was central to everything she did, and 
even seemed to overshadow her union with God to the point that she may have taken this for granted. Her writings on her journey to God, seen in her autobiography and other works, present her as someone special, someone who was chosen by God for a greater purpose over other saints, living or dead. Other persons could indeed achieve a relationship with God, including of course her mystical mentors, but it would not and could not be like that which she experienced. Of course, those who desired to be united with God would have the best luck of getting close to him if they were advised by his special chosen bride, namely herself. The Bible does indeed tell of this true bride of Christ - the one and only woman who would bear Christ's children and stand by his side in the glorious throneroom of heaven. This woman is the queen of the saints, and her status as Jesus' top spouse elevates her above the other saints and the angels, making her equal in importance only to the Virgin Mary. This queen of heaven, sole wife of Jesus, is the woman of the apocalypse, an obscure figure who plays a relatively minor role in the Book of Revelation. Before I address the topic of Mme Guyon as this woman of the apocalypse, it is important to establish who this character is.

Chapter twelve of the Book of Revelation, found in the New Testament, is thought to have been penned by the apostle St. John in the later first century A.D. This chapter, like the entire piece, contains the visions of John given to him by the Lord (I have included the quotation of chapter twelve in Appendix A). It begins with a description of a woman standing in the heavens upon the 
moon, wearing a crown of stars on her head, and covered by clothes made of the sun gently draped over her body. She wails from the pains of childbirth, and a closer examination reveals that she is heavy with pregnancy (verses 1,2 ). Beneath her feet stands a giant red dragon, with seven heads and ten horns, waiting for the woman to deliver her child so that he can devour the baby as it emerges from her womb (verses 3,4 ). Finally, she brings forth the male child, who is destined to rule over all the nations of the world. Before the baby can fall into the mouth of the dragon, however, God sweeps the baby away and places it on the throne of heaven. The woman is then able to flee into the wilderness, where God has prepared a place for her to live (verses 5,6 ). In verses $7-9$ the dragon, called the devil or Satan, is cast out of the heavens by Michael and his angels. This angers the dragon tremendously, and he begins to roam the earth searching for the woman. To save her, the mother of his child, God gives her two wings so that she will be able to escape the grasp of the dragon (verses 13, 14). Unable to find this woman, the dragon becomes even more angry, and vows to make war on her child, the son of God, and the rest of her seed who keep the commandments of God (verse 17). The chapter thus ends with the promise of the continual battle between God and Satan.

There are countless interpretations of the Book of Revelation; the purpose of this thesis is not to reinterpret this enigmatic work. Early Church fathers interpreted the woman of the apocalypse as the Blessed Virgin Mary, but this 
interpretation seems to have been out of use by the Early Modern period. ${ }^{116}$ Many theologians seek to show that the woman represents the state of Israel. ${ }^{117}$ Others claim that this female figure represents the Church, and the dragon portrays the antichrist attempting to break this institution apart. ${ }^{118}$ Mme Guyon herself provided an interesting, and highly controversial, interpretation of the Book of Revelation which will be examined in the next chapter. Overall, some points regarding this story must be clarified for the upcoming discussions. This woman of the apocalypse is the bride of God because she is bringing forth his seed, and because in the opening lines she is standing in heaven above all other women with fantastically rich garments, and is wearing a crown. As we are told by other verses, she is the mother of God's Word on earth, and her children will seek to uphold his truths against the charges of the dragon/devil. God is constantly watching out for her and protecting her, as shown by his preparation of a safe place for her to stay, and by the fact that he equipped her with wings like an angel. She is the chosen one of God, above all other members of the heavenly choir, and it is through her that Christ's word conquers the earth.

This general analysis of the issue of sanctity, as well as the discussion on the woman of the apocalypse, provides the necessary background for delving into the mysterious convictions of Mme Guyon. As we will see in the next two

\footnotetext{
${ }^{116}$ Herman B. Kramer, The Book of Destiny (Rockford, IL: Tan Books and Publishers, Inc., 1955), 276.

${ }^{117}$ See, for example, J. Vernon McGee, Reveling Through Revelation, part II (Pasadena: Thru the Bible Books, n.d.), 1-9; Gerhard Krodel, Revelation (Minneapolis: Augsburg Pub. House, 1989), 235.

${ }^{118}$ See Kramer, 275-276.
} 
chapters, she addresses the issue of being a living saint frequently, especially when constructing her Vie. This, however, was only the beginning. Through careful means she constructed her own image into that of the travailing woman of the apocalypse, true bride of Christ and mother of his children. 


\title{
Chapter 3 \\ Mme Guyon as Saint: \\ The Woman of the Apocalypse Reveals Herself
}

\begin{abstract}
He who has overcome through dying inwardly has a wonderful advantage reserved for him by God. In this band of believers the Lord Jesus himself reigns.... All these (but how rare, and how few, they are) will 'have power over the nations,'... These believers, dead to love of self, have divine power. ${ }^{119}$

Jeanne Guyon
\end{abstract}

God will one day harvest His enemies because He wants to leave on earth an assembly of righteous people and Saints. Then God, tired of the wickedness of the ungodly who torment His servants, will deliver them from oppression. ${ }^{120}$

Jeanne Guyon

In the last chapter I attempted to compose a general picture of the life and characteristics of many Catholic saints in order to establish a background for Mme Guyon's self-canonization process. As well, I relayed the basic details of the woman of the apocalypse, whose starring role in chapter twelve of the Book of Revelation as the wife of Christ and mother of his child can be linked with Jeanne Guyon's mindset during her examination by the Council of Issy. The current chapter will present evidence from Mme Guyon's large selection of writings which confirm that she considered herself a crucial member of the Glorious Orders. In the first section, general proof of self-canonization is given, most of which will be drawn from her Vie. I will save more specific details of how she used the autobiography in recreating a virtual saint's life, however, for

\footnotetext{
119 Jeanne Marie de La Mothe Guyon, Christ Our Revelation, Trans. Gene Edwards (Sargent, GA: Seed Sowers Press, 1985), 16. Referred to in the footnotes as Revelation.

${ }^{120}$ Guyon, Revelation, 102.
} 
chapter five. Next, in order to show the progression from a member of the 'normal' ranks of saints, I assert that she raised herself to the level near that of Jesus, and considered herself as having a pivotal role in the coming of New Jerusalem. The sexual connotations of Mme Guyon's writing will be examined, as it proves interesting how she manipulates her mystical relationship with Christ to describe him in three distinct contexts - as lover, as seducer, and as spouse in order to emphasize (or de-emphasize) her role at any given point. In correspondence with this clever manipulation of Christ's sensuality, I demonstrate that the only identifiable bride of Christ to appear in Scripture, the travailing woman in the Book of Revelation, becomes Mme Guyon herself. Thus, by the end of this chapter the full doctrine of Guyonist belief - as a living saint who, as Jesus' only real spouse, will assist him in introducing a new heaven and a new earth - will be discernible.

Tracing the sanctification of Mme Guyon in her writings is a relatively easy task, as examples display themselves unblushingly within her text as though they are resplendent exclamation points. Immediately, the mystical attributes of Mme Guyon must be considered, as she practiced a spiritual journey to union with God much like that of the medieval and Reformation Catholic mystics. ${ }^{121}$ The success of her being a 'chosen one' in God's elect determined that she

\footnotetext{
${ }^{121}$ This thesis is focused more on the specific attributes of Mme Guyon's mystical beliefs, and will not describe in any great detail her own journey to union with God. Like the other Catholic mystics, Mme Guyon has various steps which she passed through to achieve this state. The best description of her
} 
reached the top, most perfect form of union with the Lord, in the early 1680 's. Due to her constant state of union with God after this point, she was unable to act in any way which was not according to his Divine Will. In her Vie she described this as: "so my soul was lost in God, who communicated to it His qualities, having drawn it out of all that it had of its own." ${ }^{122}$ Such a condition, whereby all self-love and self-interest suffers destruction in a long and painful process directed by God, was only allowed to a few persons who were the saints of heaven. Likening her own experiences to these holy persons she exclaims, "I thought I experienced something of the state which the apostles were in, after they received the Holy Ghost. I knew, I comprehended, I understood, I was enabled to do everything necessary." ${ }^{123}$ As a follower of the inner way, Mme Guyon further explains that her soul was perfectly content in such a state:

What, then, renders this soul so perfectly content? It neither knows, nor wants to know, anything but what God calls to it. Herein it enjoys divine content, after a manner vast, immense, and independent of exterior events; more satisfied in its humiliation, and in the opposition of all creatures, by order of Providence, than on the throne of its choice. It is here that the apostolic state begins. But do all reach this state? Very few, indeed, as far as I can comprehend. ${ }^{124}$

In the highest level of unity with God, the soul is combined with his essence, and is then completely void of self-will. The soul in this state is content, as confirmed by Mme Guyon, despite the fact that it is being attacked and scorned

spiritual journey can be found in Moyen court (Experiencing the Depths of Jesus Christ), where she lays out the path in a relatively straightforward manner.

122 Jeanne Marie de La Mothe Guyon, Jeanne Guyon: An Autobiography, Trans. Gene Edwards

(Chicago: Moody Press, 1970), 239. Referred to in the footnotes as Vie.

${ }^{123}$ Guyon, Vie, 232.

124 Guyon, Vie, 264. 
by external forces. This "apostolic state," a phrase meant to draw a direct connection between this manner of existence and that of the twelve apostles of Christ, seeks to further isolate union with God above all other states of being. When asking how many persons ever reach this level, shared by Jesus' own chosen men who have since become saints of the Church, she answers unhesitatingly: "very few." Mme Guyon places her status above most others. Not only does she explicate the supreme level of mystical union for regular persons, however, she restricts this status in regards to admitted Catholic saints as well.

In her many exhortations about the inner way, Mme Guyon was particularly interested in placing herself above admired saints who taught a similar experience of Pure Love and mystical union. By placing herself among the top "few," she then attempted, by skillfully placed comments scattered throughout her several volumes, to discredit those recognized mystics who might be standing beside her in the ranks of heaven. The most fetching refutation lies in chapter nine of the Vie, where Mme Guyon states that the methods used by other mystics who preceded her in gaining union with Christ, were not as superior as her own. She writes: "Such was the prayer that was given me at once, far above ecstasies, transports, or visions. All these gifts are less pure, and more subject to illusion or deceits from the enemy [the devil]." ${ }^{125}$ In one short instance of pushing her feather pen briskly across a sheet of paper, Mme Guyon discredits the whole of Catholic mysticism which came before her not only as less "pure" than that which she experienced, but as being highly susceptible to 
the devil. Of course, most of the major Catholic mystics like St. Teresa of Avila, St. John of the Cross, St. Catherine of Siena, Hildegard von Bingen, Blessed Angela of Foligno, Julian of Norwich, and even Thomas à Kempis described their spiritual journeys to union with God in terms of visions, spiritual journeys, and ecstasies. Even the so-called founding fathers of Catholic mysticism, Plotinus and Dionysius the Aeropagite, used these same methods to describe their three steps to union, or their "way to God." ${ }^{126}$ Thus, by discrediting these attributes of the traditional inner way, Mme Guyon carved a place for herself above the crowd.

Not wanting to be misinterpreted, Mme Guyon explains why in the Vie, as God has told her, these methods of the mystics are not part of the higher spiritual journey. Of visions, she says, they are "inferior powers of the soul, and cannot produce true union. The soul must not dwell or rely on them, or be retarded by them." ${ }^{127}$ Further, these visions "convey a vanity to the soul, or at least hinder it from humbly attending to God only." Thus, the visions described by persons like Angela of Foligno, or Hildegard von Bingen, are dismissed for having the quality of self-love which ultimately prevents the individual from achieving perfect union. Such an attack continues when Mme Guyon asserts that ecstasies, a favorite in mystical literature, "arise from a sensible relish. They may

\footnotetext{
125 Guyon, Vie, 76.

${ }^{126}$ For general descriptions of Catholic mysticism, see Evelyn Underhill, Mysticism (New York: E.P. Dutton, 1961); F.C. Happold, Mysticism: A Study and An Anthology (Baltimore, MD: Penguin Books, 1967); Evelyn Underhill, The Mystics of the Church (New York: Schoken Books, 1964); Nelson Pike, Mystic Union: An Essay on the Phenomenology of Mysticism (Ithaca, NY: Cornell University Press, 1992); Elizabeth Petroff, Body and Soul: Essays on Medieval Women and Mysticism (New York: Oxford University Press, 1994).
} 
be termed a kind of spiritual sensuality, wherein the soul letting itself go too far, by reason of the sweetness it finds in them, falls imperceptibly into decay." 128 The ecstasy, a final goal of union described by saints like Teresa of Avila, was merely a sexual illusion which caused the soul to become corrupt. The result of this was that the soul became hindered "from following Jesus Christ in the way of renunciation and of death to all things." 129 The perfect union with God, described by Mme Guyon as the death of the self, was impossible for these persons to attain, as they practiced a method which could not possibly, by its nature, have led them to Christ. Further, Mme Guyon addresses the voice of God present in other mystics' works. This voice, the same which told Angela of Foligno she was the most beloved woman in central Italy (see chapter 3), was "subject to illusion; the enemy can form and counterfeit them." ${ }^{130}$ If, perchance, God did send one of these mystics a message, he would have done so through an angel, "for God Himself never speaks thus." ${ }^{131}$ This message, heard by the individual as "distinct interior words," were construed "in a human and carnal matter. ${ }^{\prime 132}$ Consequently, any of the messages that the mystics of the past believed they had received from God were not from him directly, but from a messenger. Furthermore, they were often mistakenly interpreted, according to Mme Guyon, because of human ignorance or misunderstanding. So how did

\footnotetext{
${ }^{127}$ Guyon, Vie, 76.

${ }^{128}$ Guyon, Vie, 76.

129 Guyon, Vie, 77.

130 Guyon, Vie, 77.

131 Guyon, Vie, 77.

$\$ 32$ Guyon, Vie, 77.
} 
God speak with his chosen ones if not by sending them interior words, visions, or ecstasies? Mme Guyon had the answer:

The immediate word of God has neither tone nor articulation. It is mute, silent, and unutterable. It is Jesus Christ Himself, the real and essential Word who in the center of the soul that is disposed for receiving Him, never one moment ceases from His living, fruitful, and divine operation. Oh, thou Word made flesh, whose silence is inexpressible eloquence, Thou canst never be misapprehended or mistaken. ${ }^{133}$

Through eliminating the other Catholic mystics from the ranks of heaven by renouncing their major methods of union with God, Mme Guyon established herself above them all; it was she who had the true, highest union with God. How else did Jeanne Guyon establish herself as a living saint? There is much proof in her writings that she considered herself on a level in heaven comparable to Jesus (that is not to say exactly equal with him, but assuredly close). As the chosen one of God who experienced perfect union with his Divine Will, she iwas made to endure trials similar to those of the mortal Jesus seventeen centuries before. ${ }^{134}$ As the examples below will show, unlike the experiences of other mystics, it was not the choice of Mme Guyon to undergo the sufferings of Jesus. These, instead, were forced upon her by God because she was his chosen one, and thus these trials served to place her in near-equal status (as co-heir) with Jesus. For example, Mme Guyon asserts in her Vie that there are

\footnotetext{
133 Guyon, Vie, 77.

134 There is a condition in mysticism where the mystic would try to reenact the suffering and life of Christ in order to feel closer to him. For example, St. Catherine of Siena would hold a doll and pretend it was the infant Jesus. Angela of Foligno, like many others, would imagine herself being crucified in order to try to mentally feel the pain of Jesus. I am not speaking of such actions here, which were done
} 
souls, such as Jesus' long ago, which sought the direct path to God by the inner way: "The souls which walk in the other path [the inner way] are often very little known, for a length of time, as it was with Jesus Christ Himself, till the last years of His life. Oh, if I could express which I conceive about this state!" ${ }^{135}$ Mme Guyon laments that she was not widely acknowledged in her day for having found true union with God, but likened this state of obscurity to that of Jesus. Not only that, she asserts in this passage that Jesus was the founder of the inner way to God, and thus by following the same method, she was following in the steps of Christ. In a similar manner, Mme Guyon often invokes the words of Matthew 8:20: "The foxes have holes, and the birds of the air have nests, but the Son of man hath not where to lay his head." Like Jesus, she says, she often had nowhere to go, being turned out of homes and inns because of her interior sanctity. Mme Guyon writes regarding her period of homelessness in 1683, "this I have since experienced in all its extent, having no sure abode, no refuge among friends... nor among my relations." ${ }^{136}$ By quoting the above passage of Matthew right after this assertion, she seems to draw comfort in this condition, as it likens her to Christ. This same line of scripture is quoted again in the Vie during Mme Guyon's unplanned journey to Grenoble in 1686. Similarly she claims that the Lord wanted her to suffer as Jesus did, and did not provide her with a place to stay. "I apprehended that our Lord was beginning in earnest to

by the choice of the individual mystic. I am referring to Mme Guyon claiming that God made her suffer like Jesus because of his will, and not because she purposefully chose to do so.

${ }^{135}$ Guyon, Vie, 265.

136 Guyon, Vie, 288. 
take from me every place of abode; and those words [of Matthew 8:20] were renewed in my mind...." ${ }^{137}$

The Vie is not the only place where such references to the similarity of her life to Jesus' are made; the commentaries of Mme Guyon on the Book of Revelation are, themselves, revealing. Regarding this text of the New Testament as a symbolic description of the soul's journey to God, Mme Guyon sought to show that those who were united to the Lord "will be received by Him as children of adoption, heirs of God and co-heirs with Jesus Christ." ${ }^{138}$ In this scenario, she, as one who was united to God, was co-heir with Christ. That is, she was on the same level as Jesus when it came to inheriting the kingdom of heaven. A passage from Moyen court et très facile pour l'oraison que tous peuvent pratiquer très aisément (known in translation as The Short and Easy Method of Prayer and Experiencing the Depths of Jesus Christ), Mme Guyon's first and most controversial book, makes the same affirmation regarding kinship in heaven. She states, "Who is this Spirit that works in you? He is none other than the Spirit of Jesus Christ. Through this Spirit we are made to share in His Sonship." ${ }^{139}$ Once again, Mme Guyon asserts that to achieve total union with God was to procure status as "son" of God, comparable in station to Jesus Christ. Reinforcing this position, Mme Guyon states that the person who was united with God was given a new name. She says, "he will use this person for

137 Guyon, Vie, 333.

138 Guyon, Revelation, 19. 
the salvation of many souls and will impart to that one His sufferings by crucifying that one with Him." ${ }^{140}$ Thus, because she received a new name as part of losing her "own identity through nothingness," and uniting with God, she was subjected to trials like those Jesus suffered. In a final example, Mme Guyon expressed acknowledgement of the pain Jesus suffered during his life, as she believed she was suffering comparably. She states, "Jesus Christ produced righteousness on the cross and His grief was extreme. What pain must be known to produce such righteousness!" ${ }^{141}$ As a walker in the inner way, she necessarily had to "produce righteousness." ${ }^{142}$ By likening herself to Jesus by claiming that she had experienced a pain like that which he suffered mentally during the crucifixion, Mme Guyon again fortified her position as "co-heir" to the throne of God.

As further confirmation that Mme Guyon raised herself to a level near that of Jesus in the Glorious Orders, her path to union with God was actually structured like the life of Christ. Of course, in this scenario, those who would follow the path she suggested and who could actually achieve the final union would become like Christ. The best manual for understanding this connection is the Moyen court, where Mme Guyon presents her method of the inner path in four stages: the beginning, the progress, the achievement, and the

139 Jeanne Marie de La Mothe Guyon, Experiencing the Depths of Jesus Christ, Trans. Gene Edwards (Sargent, GA: The Seed Sowers Press, 1975), 103-104. In this thesis I refer to this work as the Moyen court in order to reflect its original French title.

${ }^{140}$ Guyon, Revelation, 23.

${ }^{141}$ Guyon, Revelation, 80.

142 Guyon, Revelation, 80. 
consummation. ${ }^{143}$ We see that the beginning stage is like that of a child trying to find its way, much like the infant Jesus. Mme Guyon says to those who are starting out, "Dear child of God, your Father has His arms of love open wide to you. Throw yourself into His arms." ${ }^{144}$ The child is taught by simple exercises and repetitive labor. For Jesus this was debating with theologians and helping his father as a carpenter, and for Mme Guyon, this stage involved "praying the scripture" and "beholding the Lord". ${ }^{145}$

Progress is made while the individual matures, much like Jesus did, by practicing these methods of prayer and reflection and by abandoning themselves more and more to the influence of God. In this stage, the seeker of the inner way must relinquish their self-will to God and begin to act only as he dictates: "As you come to the Lord to pray, bring a full heart of pure love, a love that is not seeking anything for itself. Bring a heart that is seeking nothing from the Lord, but desires only to please Him and to do His will." ${ }^{146}$ This period of progress is also marked by the onset of great suffering and trials sent by God in order to initiate a greater union with the soul of the believer. The Lord will disappear for long periods of time in order to induce the individual to beg for his return. Why? "His purpose is to rouse you from spiritual laziness." ${ }^{147}$ During this stage, the Lord also sends the believer great suffering in order to assert his Divine Will over them. Mme Guyon writes, "You must learn to love the cross. He who

\footnotetext{
143 Guyon, Experiencing, 102.

144 Guyon, Experiencing, 2.

${ }^{145}$ See chapter 2 and 3 of Experiencing for more details on the suggested methods of Mme Guyon.

${ }^{146}$ Guyon, Experiencing, 24.
} 
does not love the cross does not love the things of God.... Here is a true spiritual principle that the Lord will not deny: God gives us the cross, and then the cross gives us God." ${ }^{148}$ Jesus Christ, in his lifetime according to the Gospels, was similarly scorned and ridiculed for his preaching and activities. Mme Guyon would say that the Lord was testing him, just as the Lord tests all those who desire to walk on the inner path.

The third stage described by Mme Guyon was that of actual achievement of union with God, "a state of silence and continuous prayer." ${ }^{149}$ This condition, as she describes it, is very similar to that of the "unitive" way of Richard St. Victor, Jacopone da Todi, and their inspiration, Dionysius the Aeropagite. ${ }^{150}$ In this union, the soul of the individual mystic is led by God alone. Mme Guyon's theory agrees with this interpretation, but for her this was still not the final step. The achievement stage can be likened to Jesus' adulthood leading up to, and including, the crucifixion. Slowly, God prepares the believers (as he did Jesus) for their deaths, which Mme Guyon confirmed as the crucifixion of the self. The soon-to-be crucified soul lays aside most of its self-interest and resides constantly in the presence of God. At this point the Lord finds and absolves all the sins of the one in union with him: "Depend upon your Lord, not on yourself, to expose your $\sin$ and to show you the extent of your $\sin .{ }^{\prime 151}$ Spoken prayer right before

\footnotetext{
${ }^{147}$ Guyon, Experiencing, 27.

148 Guyon, Experiencing, 38.

149 Guyon, Experiencing, 69.

150 See Evelyn Underhill, The Essentials of Mysticism, chapter one for more on the similarity of the "unitive" stage, called "ecstasy" by Richard St. Victor and "hidden heaven" by da Todi.

151 Guyon, Experiencing, 74.
} 
crucifixion of the soul is no longer necessary, as the Lord will make one pray according to his own desires. Mme Guyon states, "Yes, you have a will; yes, you have desires and requests. Nevertheless, let Him have the will, the desire, that is in the prayers He prays."152

This condition of prayer is reminiscent of Jesus praying in the garden of Gethsemani shortly before his arrest. Jesus prayed in the presence of God, and because he was united with God, was directed in prayer by the Lord. By allowing the Lord to put the prayer into his mind, Jesus was able to find out about his impending imprisonment and death. According to Mme Guyon, the soul also knows, like a frightened but strong-willed Jesus in Gethesemani, that it is about to die. She urges the believer on, however, despite the hesitancy of the soul: "It is by the utter destruction of self that you acknowledge the supreme existence of God. The hour must come when you cease all living in the realm of the self! You must cease to exist in self so that the Spirit of the Eternal Word may exist in you." ${ }^{153}$ Mme Guyon then describes the dying of the soul as a sacrifice for eternal life, reminiscent of the sacrifice of Jesus so that sinners could have the chance to go to heaven. She states, "by the giving up of your own life, you make way for His coming! And it is in your dying that He lives!" ${ }^{154}$ Thus, the achievement of union was not the end for Mme Guyon, but a stage in which the soul continued to advance until it suffered a painful crucifixion, as Jesus did.

Guyon, Experiencing, 82.

153 Guyon, Experiencing, 90.

154 Guyon, Experiencing, 90. 
The ultimate Christian attainment according to Mme Guyon is that of consummation, or "Divine Union." ${ }^{155}$ The soul has been crucified by God, has suffered the death-agony of the expiring of self-will and self-interest, and is resurrected. Her words speak best of this achievement:

You have come to uniformity. This is beyond a passive state. Or at least it is the ultimate end of the passive state. It is at this point you begin to yield yourself up to the impulses of the divine Spirit until you are totally absorbed with Him. You are in total concert with His will in all things at all times. This is union. Divine union. The self has ended. The human will is totally passive and responds to every movement of God's will. ${ }^{156}$

The soul has died, and is resurrected in God. Mme Guyon necessitated that those who partook of this spiritual journey were following paths similar to those of the mortal Jesus Christ. To follow her doctrine was to be on the path to becoming an heir of God. Of course, it is necessary again to confirm one very important detail in all of this: only the chosen few could ever attain consummation. Mme Guyon writes, "This cannot be brought about merely by your own experience. Meditation will not bring divine union; neither will love, nor worship, nor your devotion, not your sacrifice. Nor does it matter how much light the Lord gives you. Eventually, it will take an act of God to make union a reality. ${ }^{157}$ Further into this same chapter of Moyen court, she reinforces this point so that the reader will not be mistaken: "No one can put himself into union with God. It would not be possible, no matter how great the effort. The

\footnotetext{
155 Guyon, Experiencing, 125.

${ }^{156}$ Guyon, Experiencing, 133.

157 Guyon, Experiencing, 125.
} 
soul's union with God is something God alone does." ${ }^{158}$ Consummation, the highest level of union obtainable for the Catholic mystic, was attainable by only a very few persons whom the Lord had chosen. Of course, since Mme Guyon had spoken and written about this condition, we are forced to assume that she had achieved it. Similarly, by getting to this stage, she (or her soul) followed a course similar to that of the mortal Jesus Christ, and in the words of the Nicene Creed, "suffered, died, and was buried." Like the son of God, she was resurrected and, as an heir, "is seated at the right hand of the Father." The Creed continues, saying that Jesus "will come again in glory to judge the living and the dead. His kingdom will have no end." This premonition of the apocalypse and the coming of New Jerusalem has special meaning in relation to Mme Guyon for, as the following sections will show, she believed herself to be one who would stand beside Jesus in judging the living and the dead on the basis of their practice of Guyonist prayer.

In Mme Guyon's writings, the figure of God assumes many forms -physician, shepherd, and father - while that of Jesus is reserved for sensual connotations including lover, seducer, and spouse. This might not seem outstanding, as many of the Catholic mystics adopted a similar style of speaking of Christ in terms of a romantic relationship. However, when combined with Jeanne Guyon's assertion that she was the only bride of Christ, and was the only one who was mother to his children, these sensual terms take on new meaning.

${ }^{158}$ Guyon, Experiencing, 136. 
Mme Guyon created and manipulated her various images of Christ in order to emphasize not only the uniqueness of her relationship with him, but also to confirm her chosen status.

The eminent abandonment dialog of Mme Guyon, referred to as the "period of dryness," presents the most usual source of references to Jesus as being her lover and describes periods when the Lord would leave a believer without any warning or reason. After a long absence, during which the believer would pray heartily and faithfully, the Lord would return in his full glory, bestowing on his disciple a deeper spiritual fulfillment. On this concept of a longing and patient human lover, she writes:

If the Lord's presence tarries for a long time, then the dear believer will once more slip into forgetfulness... [Until] he feeds once more upon the caresses and love of his Lord. Chances are, then, if the Lord does return bearing His riches, and remains for a good period of time... He will almost surely depart again! ${ }^{159}$

This passage displays several aspects of Mme Guyon's beliefs. First, that the Lord would come and go as he pleased, a result of which the believer might fall into a period of "forgetfulness," or rather, a forgetting of the pleasures of being with the Lord. Then, when Jesus returned he provided "caresses and love" (his "riches") as though to make up for his absence. What is interesting here is the use of the word "feeds," which implies that the believer became famished during the absence of Christ and fell ravenously on the meal of love that the Lord brought upon his return. However, one must not get too used to having such a

\footnotetext{
159 Jeanne Marie de La Mothe Guyon, Spiritual Torrents, Trans. Gene Edwards (Sargent, GA: The -Seed Sowers Press, 1990), 36.
} 
feast, as Jesus would surely leave again, and the hunger and forgetfulness would return. What is more striking about this passage is the attributing to the Lord qualities of an earthly lover. He went away for an amount of time, then came back to his lover for physical pleasures, got restless, and left again. The abandoned lover constantly waits impatiently, never losing hope for his return, and looking towards that moment with great anticipation. Following this model, other passages from the text and poetry of Mme Guyon assume expanded meaning. In several, a previously confusing dialog of passive scolding gains new clarity:

Have You loved us only to leave us? You wound the soul, and then cause it to run after the author of the wound. You draw them after You. You show them Yourself. And when they have possessed You, You flee away... O harsh lover, $\mathrm{O}$ innocent destroyer, why do You not slay at once? ${ }^{160}$

Many of the texts of Mme Guyon become pseudo-love poems intended to gain back the attentions (sensual and otherwise) of the Lord. In this passage she clearly desires his constant attention, and when he leaves her Jesus becomes a "harsh lover... [an] innocent destroyer," mangling her heart and soul over and over again. It is a pain which she could not bear, but out of force because she was the lover of Jesus -- such agony came with the territory.

In Moyen court, Mme Guyon presented the stages to divine coupling: "The experience of union with God comes to us in four stages: its beginning, its progress, its achievement, and its consummation." ${ }^{161}$ While the term

\footnotetext{
${ }^{160}$ Guyon, Torrents, 29-30.

161 Guyon, Experiencing, 102.
} 
"consummation" could refer to a completion, a bringing to a close, it is also possible that a sexual tone could be implied. This joining with God is seen as the ultimate goal, the clear sign that one has reached the pinnacle of the earthly, mortal experience. In her poetry Mme Guyon represented this final stage as a loving couple privately being together:

Here sweetly forgetting and wholly forgot, By the world and its turbulent throng,

The birds and the streams lend me many a note, That aids in meditation and song....

Your shades are a temple where none will intrude -The abode of my lover and Lord.

$\mathrm{Ah}$ ! send me not back to the race of mankind... Though lost to the world, if in union with Thee, I am holy, and happy, and wise. ${ }^{162}$

She describes a lovely retreat to nature where the mortal, physical world is forgotten, and where she can constantly sing praises to her "lover and Lord." And there in this paradise, Jesus protects her from reality and from the eyes and caviling of others, taking care of her needs so she may be "holy... happy, and wise." She begs her lover not to return her to the world in which he does not exist (i.e. the mortal, physical world). As was seen above in the writings of the thwarted lover, Mme Guyon appears to recreate an inner, mental world where Jesus is her only partner, and an ideal and perfect one at that.

The writings of Mme Guyon display Jesus as a purposeful lover actually choosing those with whom he wants to have "intercourse". In the basic first steps of Guyonism, the Lord attracts certain souls whom he desires to fill with Pure 
Love. Mme Guyon expresses this as a divine choosing of individuals to receive his attentions. She states:

The Lord is so simple in His attraction of you. This attraction of His is both an ointment to heal and a perfume to allure you to Himself... His attracting force is extremely powerful, and yet the soul follows freely and without force. Why? Because the attracting of your Lord is just as delightful as it is powerful! Although his attracting of you is powerful, it carries you away by its sweetness. ${ }^{163}$

Thus, the Lord actively tries to seduce his chosen ones (those whom he is attracted to) into uniting with him. He enchants them with "an ointment to heal (their sins and sorrows) and a perfume" -- a transcendental version of dressing fancy for an admired one and bringing her a gift. Because he is God and is allpowerful, the soul follows him without reservation. However, it is not only by force that he makes the individual follow him, but also because he is "delightful," and the "sweetness" of the Lord's attraction is unable to be ignored. Mme Guyon recreates the perfect seduction -- a powerful, charming, charismatic Christ (man) bearing gifts to enrapture the individual (woman) and make her his lover.

A major point discussed by Mme Guyon is how one would go about attracting the Lord to oneself. While she points out several ways, such as being good in spirit and approaching him quietly and patiently, it is worth mentioning that Mme Guyon thought of virginity as a major obstacle to gaining the initial attention of Jesus. Of this condition she said that:

\footnotetext{
162 Jeanne Marie de La Mothe Guyon, Union with God, Trans. Gene Edwards (Sargent, GA: The Seed Sowers Press, 1981), 96. From the poem, "Union with Thee."

${ }^{163}$ Guyon, Experiencing, 96-97.
} 
But those who consider themselves good and have not known many weaknesses have many problems, too. Take, for instance, the virgin, or someone who has taken chastity as a vow... Remember, your Lord makes his mercies abound where sin has abounded. Careful that you do not love your own righteousness... You will never know the center of God by an exalted view of yourself. ${ }^{164}$

In this interesting and provocative view, Mme Guyon exerts that the Lord absolutely does not want followers who are sexually inexperienced. In her mind virgins were, by nature, self-righteous and narcissistic, and thus Jesus was not interested in their self-motivated ways. As well, the clear message expressed here is that God was attracted to sinners, or rather, to those who acknowledged that they were sinners. Mme Guyon seems concerned that the virgin imagined herself sinless because she had never had sexual intercourse, and thus was potentially full of self-righteousness. Such persons could never achieve union with God because of their self-love manifested by sexual purity. It seems more realistic, however, that this passage is more a reflection of how Mme Guyon felt about herself rather than an actual requirement of the pure love of God. She may have been expressing dissatisfaction at her own condition as a formerly married woman which removed her from accepted saintly piety. This aspect of Guyon's teachings - that the traditional Catholic virgin was unacceptable as a bride of Christ - will be further examined in later chapters as justification for her sanctity.

${ }^{164}$ Guyon, Torrents, 18. 
After the initial attraction of the sinner, the Lord would initiate a more involved pursuit of the object of his desire. To Mme Guyon, this chase was allencompassing and impossible to disrupt:

His loving pursuit of man is more than we can imagine. Some believers he pursues with not so much as an intermission. He seats Himself beside their door, attains them, and delights Himself in being with them at all times, and in loading them with expressions of His love. ${ }^{165}$

In other words, the Lord patiently and without rest pursues an individual, and acquires believers by the force of never leaving them alone. This contention that the Lord actively pursued the believer can also be confirmed by the following phrases from the poem "Prisons do not Exclude God":

Strong are the walls around me, That hold me all the day; But they who thus have bound me, Cannot keep God away...

He makes my dungeon's darkness bright, And fills my bosom with delight.

Thy love, O God, restores me From sighs and tears to praise; And deep my soul adores thee, Nor thinks of time or place:... Converting woe to pleasure, And reaping joy from pain... ${ }^{166}$

According to Mme Guyon, God would find his believer, the one whom he is attracted to, through any measure necessary, and the human world of bricks and mortar cannot keep him from his chosen one. Within the lines "He makes my dungeon's darkness bright, And fills my bosom with delight," the concluding words from the previous passage are echoed -- he fills his believer with love. All

\footnotetext{
${ }^{165}$ Guyon, Union, 67-68.

${ }^{166}$ Guyon, Union, 108.
} 
of the trials of life and imprisonment disappear when the Lord is with his chosen; he takes away all pain, all woe, all melancholy, and turns them into the divine worship and loving of himself.

In the second part of Spiritual Torrents, Mme Guyon gives a lengthy discussion of how the Lord prepares his chosen ones for the experience of "ecstasy." She writes:

The soul, in truth, is in a state of transport and ecstasy... The weakness comes from this, that God drawing the soul, as it were, away from itself, to lose it in Himself, but the soul being neither pure enough nor strong enough to endure that drawing, ... God should cease from drawing the soul [away from itself], whereby the ecstasy comes to an end... But here the ecstasy has place perpetually, and not for a few hours only, without violence or injury, God having purified and strengthened the subject to the degree necessary for bearing this wonderful ecstasy. ${ }^{167}$

Before imparting the final stage, or "consummation" upon those he has chosen, the Lord must prepare them to withstand his ecstasy. Accordingly, the union is so strong that many are unable to handle the process of ecstasy, whereby God draws the soul away from itself. If the individual had a soul that was not pure enough or strong enough to endure this process, the Lord would quit, and the ecstasy would cease. However, Mme Guyon seems to be saying that by practice one can strengthen one's soul to withstand this union with God "not for a few hours only." This ethereal, sensual coupling with God leads to the union with God, when he takes the believer as his lover. Thus, the ecstasy becomes something that both the Lord and his follower (and as we shall see, his bride)

\footnotetext{
${ }^{167}$ Guyon, Torrents, 88-89. The ecstasy described by Mme Guyon is similar, but not exactly parallel with, the ecstasy of earlier Catholic mystics. As well, ecstasy is to her only a step on the path to union with God, and does not constitute union in itself.
} 
share -- much like in the corporeal world. At this stage, however, it is clear that the actual consummation has not occurred; as Mme Guyon has told us previously, ecstasy is an indication, if unreliable, of union with God, but does not itself constitute the end of the journey.

He has loved, and he has pursued, and in the final symbolic representation of Jesus for Mme Guyon, he marries. It has been common for Catholics to refer to God as the bridegroom of the church. In the case of St. Bernard of Clairvaux and other mystics, the bride was the individual who married Christ through mystical union with him. However, the repetitive nature of the concept of bride and bridegroom in the work of Mme Guyon goes far beyond this simple parallel. Like other mystics, to her the bride of God was not the Church (as in the established Catholic Church), but the individual. As discussed above, the final stage of union with God is that of consummation. To Mme Guyon, this symbolized the marriage of God with his chosen believer. She states that:

God causes the soul to pass into Himself and gives the believer such a pledge of assurance of a Divine union -- yes, even a Divine marriage -between the believer's soul and the living God. The assurance and pledge of this union is so real that the believer can no longer have any doubt of it. The consummation is complete. ${ }^{168}$

The lover of God who has been seduced by him can become part of the divine union, her "divine marriage," which must be decided upon by the Lord himself. At this point, the final stage is reached, and the believer is no longer a thwarted lover, but becomes the bride of Jesus. For Mme Guyon, this moment occurred 
while she was still married to her earthly husband, at which time she made a written marriage agreement between herself and the Lord (see Appendix B). The agreement that Mme Guyon signed was similar to those of other Christians wishing a more holy union with God -- however, it must be stated that her intentions of such an agreement went far beyond the sacerdotal union with God. As the following sections will demonstrate, she absolutely took this covenant to be a literal interpretation of bride and bridegroom.

Throughout her writings from the mid-1680's, Mme Guyon furthers this idea that Jesus was her husband. In Union with God she makes the following analogy:

the soul is united with the Lord... A young bride who has fainted into the embrace of her husband is closely united with him, but she does not enjoy the blessedness of her union with him because she is unconscious. Nonetheless, her husband holds her in his arms while she is in a state of fainting that has come from excess love. He recalls her to life again, tenderly by his caresses, and as she comes to consciousness she knows that she possesses him whom her soul loves and that she is possessed by him. So, too, is it with the believer. ${ }^{169}$

This most perfectly demonstrates her feelings towards the Lord. To Mme Guyon, she was this young, blushing bride (but not a virgin) taken by the Lord as his wife. Out of naive joy of love and being married she faints (i.e. allows Jesus to draw out her soul to give her ecstasy) and is unconscious. Instead of abandoning her at this point (as he has done in the past in the "periods of dryness") he stays with his bride and comforts her with caresses and love. When she awakens

\footnotetext{
${ }^{168}$ Guyon, Union, 60.

${ }^{169}$ Guyon, Union, 57-58.
} 
(from prayer) she knows that the Lord is within her soul, that she has abandoned her very being to be one with him, and that by having him in her soul he has taken full possession of her. It is in this crucial final step that the definition of consummation for Mme Guyon occurs and total union with God as a bridegroom is achieved. It is impossible to separate the concept of a personal marriage to God from that of a Guyonist union in discussing the doctrine of Mme Guyon; as the above discussion has demonstrated, they are necessarily interconnected.

Jesus as lover/seducer/spouse in the writings of Mme Guyon confirms that the sensuality in her text is unavoidable. Through the evidence presented several things emerge, including the stages of movement towards the ultimate union (consummation and marriage) with Christ, and the requirements of the Lord for acquiring such a goal. It becomes clear that within the very notion of Guyonism, mystical sexuality and intercourse with Jesus were absolutely necessary. As we shall see, this ethereal assertion of sexuality meant to confirm that she was the only wife of Christ, and was the sole person who could bear his children who would, in turn, initiate a new earth and new heaven. Mme Guyon, as the woman of the apocalypse, was mother to the future.

Jeanne Guyon, as a living saint and as first bride of Christ, believed herself to be the woman of the apocalypse described in chapter twelve of the Book of Revelation. So far in this chapter I have sought to discuss Mme Guyon 
as a saint in general, who then elevated herself to a position near that of Jesus by claiming that she was his true spouse. Through an examination of the ways Mme Guyon presents Jesus in her writings, I concluded that these figures of lover and seducer cumulate in that of Christ as spouse. This analysis, then, corresponds with the assertion that Mme Guyon was the woman of the apocalypse. Such a relatively obscure figure surely cannot wield so much power, but as Mme Guyon asserts, it is through this woman that the new age of the reign of Jesus will occur. The basics of the travailing woman and her offspring have been examined in some detail in chapter three of this thesis, and will not be repeated here. However, it is important to remember that this woman is the mother of the child who will initiate the new earth and new heaven, and it is by her that the Lord will spread his children over this New Jerusalem. The discussion below will show how Mme Guyon constructed herself as this woman, and reinforced this view by creating an entire doctrine based on scenarios drawn from this revealing story. Much of the material presented here will be drawn from Mme Guyon's highly controversial commentary on the Book of Revelation, an interpretation which has gained her notoriety for its amazing declarations. The editor of the translated edition warns the reader that, "there has never been an interpretation of Revelation - before or since - like this one. It is unique." ${ }^{170}$ It is unique because, as shall be shown, Mme Guyon deciphered the text not only as a description of the path to divine union with God, but also because she situated herself as a central character in St. John's enigmatic vision.

${ }^{170}$ Guyon, Revelation, editor's preface by Gene Ed\&8ards. 
Mme Guyon begins her commentary on chapter twelve in her text entitled Christ our Revelation, by addressing the woman travailing in the heavens. We are immediately told that, "this woman has two distinct meanings, all of them very true. ${ }^{\prime 171}$ For Mme Guyon, this figure represents two things: the church, and a mortal woman. These two symbols may seem in conflict with one another, and it would be natural to assume that Mme Guyon is referring to the traditional interpretation of the Church as the female figure. However, this was not the case. When Mme Guyon used the term "church" she clearly meant a collection of believers, but not that of the established Catholic Church. The church described by Mme Guyon represents the new church that will be achieved by the fall of the Catholic Church, a church based on the inner way as she taught it. She says, "the church is about to give birth to the inner spirit: her true Spirit." ${ }^{172}$ Similarly, "as the church is about to spread out her branches, she wants to produce her Spirit in all her members. This is the spirit of abandonment, and divine moving, so fought against today. ${ }^{173}$ From these two passages, it is clear that the church she is speaking of was not the Catholic Church of her day. Mme Guyon clearly states that this new spirit, that of the church she is referring to, was contested in her day. Obviously the Catholic Church was not fighting against its own beliefs. Mme Guyon is clearly referring in this passage to a new church, a body of doctrine based on the inner way to God. Who would lead this new church, then? Or more to the point, is it

\footnotetext{
${ }^{171}$ Guyon, Revelation, 79.

172 Guyon, Revelation, 80.
} 
possible that a mortal female is, simultaneously, the church? Further examination reveals that this second case appears to be correct.

The woman of the apocalypse becomes a human woman in the context of Mme Guyon's commentary on Revelation. She says immediately upon opening her discussion that in "the depths of knowing our Lord must be born on earth. It was always in Heaven, but has not been produced on earth." 174 This statement claims that the woman described in this chapter (twelve) is mortal and she was born on earth because heaven had no need of her there since the inner way was already present. This assertion is confirmed further by the physical description of the woman. She was surrounded by the sun, which Mme Guyon interprets as "truth, manifested in this life. ${ }^{175}$ She has the moon beneath her feet "because she is above unstableness and wavering." Mme Guyon comments that this was a symbol of one who knew God's intimate truths, because "when the soul of a believer is established in the truth, it does not change anymore in its foundation." The cloth of the sun that surrounds this woman is interpreted by Mme Guyon as showing that she was "above all changeable and varying lights." The crown, signifying the queen of heaven, had twelve stars representing "the twelve fruits of the Holy Spirit. The soul that has truly known Him deeply possesses them all." Thus, the figure of the woman is described in Christ our Revelation as one who had achieved divine union, and who knows the truth,

\footnotetext{
73 Guyon, Revelation, 80.

174 Guyon, Revelation, 79.

175 Guyon, Revelation, 79.
} 
that the inner way is the supreme method of attaining holiness -- knowledge which was given to her through this intimate relationship with Jesus.

The woman of the Apocalypse is distressed because she carries within her the Lord's child, and she anxiously desires to produce this fruit for the world. Mme Guyon tells us, "this fruit is righteousness." ${ }^{176}$ Mme Guyon likens the experience of the woman to that of Jesus Christ, who also labored to bring righteousness into the world: "Jesus Christ produced righteousness on the cross and his grief was extreme. What pain must be known to produce such righteousness! The inner walk must produce righteousness just as - counterwise - lies produce unrighteousness." Once again, the analogy to Jesus' life is present, as though those who suffer similarly achieve a comparable end. The woman, then, is trying to deliver righteousness through intense suffering, as Christ did through crucifixion. This woman, however, can also be the coming church described above, which sought to "give birth to the inner Spirit." ${ }^{177}$ This child, Mme Guyon tells us, is the Spirit "which is like the second advent of Jesus Christ." Hence, through the birth of this child, the woman of the apocalypse will initiate the return of Christ to the earth.

In commenting on verses three and four of chapter twelve of the Book of Revelation, Mme Guyon establishes that the looming red dragon who stands anxiously by to devour the delivered child of the woman is none other than the devil who acts through the Catholic authorities. She states: "this 'dragon' is self-

${ }^{176}$ Guyon, Revelation, 80.

177 Guyon, Revelation, 80. 
love, the father of the lie. He is opposed to pure love; he is the mortal enemy of truth... this same dragon, today, seeing that the inner Reality is going to come to light in the world, is standing firm to devour it and to hinder its appearing on earth. ${ }^{\prime 178}$ The dragon represents those who would extinguish the "truth" of the inner path to God. This scenario harkens back to Mme Guyon's persecution by Bossuet (among other Catholic authorities, as we shall see) who sought to halt her preaching about Pure Love. Indeed, those who did not follow the inner path were guilty of self-love, and "self-love produces unrighteousness and devours righteousness... This is why this horrible dragon, this Lucifer, had so many everywhere worshipping him." ${ }^{179}$ The dragon/Lucifer/Church authorities, who were widely revered, were trying to swallow the child of truth/inner way/righteousness being produced by the woman.

Her child is born, in verse five, to rule over all nations, and people of all nations submit to his rule. The woman is, then, the mother of truth on earth, and it is through her that a new age would be instigated. According to the scenario written by Mme Guyon, this child was the inner way she preached: Guyonism at its finest. This way of worshipping God would force all on the earth to submit because, as we are told, it is the "truth." After giving birth the woman of the apocalypse was sent by God into the wilderness, "to a solitary place... to hearts prepared for her." 180 "From there," continues Mme Guyon, "faith will spread out." This point could refer to Mme Guyon's flight from Thonon and Gex in

178 Guyon, Revelation, 80-81.

${ }^{179}$ Guyon, Revelation, 81. 
early 1684 and her subsequent peregrination in southern France and northern Italy, during which time she spread her doctrine as widely as possible. As the woman of the apocalypse hides in her wilderness retreat, the dragon fights with Michael and his angels in a battle of "self-love against pure love." ${ }^{181}$ The dragon is eventually defeated in heaven and fell back down to earth, where he "will exercise his cruelty for a short time... so in our souls, as long as self-love rules, Pure Love is nearly gone, living only in some solitary places, in some few chosen souls." ${ }^{182}$ Thus, the dragon rules over the earth, fostering the self-love which opposes pure love and true union with God. Clearly, this scenario could also refer to the condemnation of Mme Guyon by priests and nuns wherever she wandered during her journeys in the 1680's. The chosen persons like her, the "very few" we have encountered several times in this thesis, were those in whom the fire of the church of the inner way was still burning, which caused them to be singled out for reproach.

Turning his anger onto the woman, who was hiding in the wilderness, the dragon sought to fight against her who gave birth to the "truth." But, "the wings of an eagle are given to this one" and she hides again in the wilderness, "separated from the world [where] she is fed - helped - for the future day of her appearance. ${ }^{\prime 183}$ Again, this could refer to the period of the 1680 's, during which time Mme Guyon wandered between friends' homes and convents,

\footnotetext{
${ }^{180}$ Guyon, Revelation, 82.

181 Guyon, Revelation, 83.

182 Guyon, Revelation, 85,

${ }^{183}$ Guyon, Revelation, 86.
} 
contemplating what to do with herself. This particular passage could be intimating the period when she was accepted warmly by the bishop of Verceil in 1686 , under whose care she hid away for a time to see if the slander against her would dissipate. Returning to the commentary, the woman of the apocalypse, or the church who seeks to spread righteousness on the earth, "will never be more persecuted that by her own children. Nor will the individual believer." This phrase signifies that the church of Revelation was the doctrine of the inner way and a mortal believer, thus also reinforcing the idea presented above that the woman was both a body of beliefs as well as a living person. Both the church and the woman were persecuted by those who knew them (referring to persons who had been taught the inner way, but then who revolted against their teacher). This specific comment could be alluding to the condemnation of Mme Guyon by Father La Combe in 1685 , which was especially painful to her due to the fact that she had considered him her greatest student.

This chapter of the Book of Revelation closes with an acknowledgement that the woman had other children with Jesus, evident by fact that the dragon left her in the wilderness to go and make war with them. These children, as Mme Guyon describes them, are those "inner souls who love the truth.... Only the true children of truth are molested." 184 The woman's children are the followers of the inner way, who in turn are persecuted by the dragon for their beliefs. This stimulates one to think again of Father La Combe, who was imprisoned for his beliefs in the inner way and for being a "child" of Mme 
Guyon. This passage also refers to the fact that persecution, or "molestation," only happens to those who know the truth. Therefore, the persecution of Mme Guyon and her followers (namely La Combe) justifies the fact that they are speakers of the truth.

So, are all the connections between Mme Guyon and the woman of the apocalypse speculation on my part? My entire argument so far has attempted to draw possible connections between Mme Guyon's Christ our Revelation commentary, her life, and her teachings. Am I overstepping the boundaries of historical inquiry by making such associations? Indeed, no.

Mme Guyon's autobiography confirms the scenario I presented above, where the woman of the apocalypse was a real person who assumed the shape of Mme Guyon in the late seventeenth century. One passage from the Vie in particular provides proof that my assertions are not speculation. In an effort to make this discussion clear, the entire text of this passage is quoted as follows:

He showed me all the world in a rage against me, without anyone daring to appear to me and assured me in the ineffable silence of His eternal Word, that He would give me vast numbers of children, which I should bring forth by the cross. I left it to Him to do with me whatever He pleased, esteeming my whole and sole interest to be placed entirely in His divine will. He gave me to see how the Devil was going to stir up an outrageous persecution against prayer, yet it should prove the source of the same prayer, or rather the means which God would make use of to establish it. He gave me to see farther how He would guide me into the wilderness, where He would cause me to be nourished for a time. The wings, which were to bear me thither, were the resignation of my whole self to His holy will. I think I am at present in that wilderness, separated from the whole world in my imprisonment. I see already accomplished in part what was then shown to me. ${ }^{185}$

${ }_{184}$ Guyon, Revelation, 86.

${ }^{-185}$ Guyon, Vie, 288. 
This astounding passage was written during her imprisonment in 1688 , at a time when she was reflecting on what had happened to her in the years leading up to her incarceration. As is apparent, many aspects of the story of the woman of the apocalypse are evident: the child; the dragon and his persecution; the wings of safety; the flight of the woman to the wilderness. All of the essential elements of the story from the Book of Revelation are present in this one passage through which Mme Guyon sought to explain her own existence. The following discussion targets specific sentences from this statement in order to explain how Mme Guyon was proclaiming herself the queen of heaven.

The beginning of the quoted passage describes Mme Guyon's life in 1683 while living with the Ursulines in Thonon: "He [God] showed me all the world in a rage against me, without anyone daring to appear for me and assured me in the ineffable silence of His eternal Word, that He would give me vast numbers of children, which I should bring forth by the cross." ${ }^{186}$ As has been shown above, the woman travailed in her efforts to bring forth the child of Christ, and was persecuted for this effort by the dragon. Mme Guyon, as with the woman of the apocalypse, had many children with Jesus, namely those whom she had taught the inner way. But to gain these children, she had to undergo, like the woman of the apocalypse, great persecution. To continue in the autobiography:

${ }^{186}$ Guyon, Vie, 288. 
I left it to Him to do with me whatever He pleased, esteeming my whole and sole interest to be placed entirely in His divine will. He gave me to see how the Devil [the dragon] was going to stir up an outrageous persecution against prayer [the child], yet it should prove the source of the same prayer, or rather the means which God would make use of to establish it. ${ }^{187}$

In this passage, the follower of the inner way which has been born from the woman, namely Mme Guyon, is persecuted by the dragon who stirs up outrageous lies against it. This clearly refers to the slander that Mme Guyon faced as she taught her method of prayer, slander which had been initiated by the New Catholics in Gex and furthered by the bishop of Geneva. However, as Mme Guyon asserts again, this persecution was necessary for this very prayer of the inner way to be successful, because without condemnation, the way to divine union with God was impossible.

In the Vie, Mme Guyon continues to associate herself with the woman of the apocalypse. She writes, "He gave me to see farther how He would guide me into the wilderness, where He would cause me to be nourished for a time. The wings, which were to bear me thither, were the resignation of my whole self to His holy will." 188 We see here the flight of the woman described in the Book of Revelation into the wilderness, where she was nourished by God in order to regain her health and to hide, for a time, from persecution. Mme Guyon then speaks of the wings of the eagle, and claims that they represented in her the surrender to God's will. In further reflection, Mme Guyon felt that she was currently in this secluded wilderness, hiding from her persecutors (the dragon

${ }^{187}$ Guyon, Vie, 288. 
and his men in the form of religious authorities): "I think I am at present in that wilderness, separated from the whole world in my imprisonment." This passage, although written in the late 1680's in her Vie, refers to the period around 1683. The Book of Revelation states that the woman stayed in this wilderness, or place of seclusion, for 1260 days; interestingly enough, Mme Guyon remained in the vicinity of Gex for about the same length of time from mid-1680 to early 1684 . Also, in this passage from her Vie pertaining to her imprisonment at the convent of the Visitation on the rue Saint-Antoine between January 1688 and August 1689 , it is probable that she was referring to the second visit of the woman of the apocalypse to the wilderness which immediately followed the return of the dragon to the earth. By this, then, Mme Guyon means that the "wings of the eagle" spoken of in the Book of Revelation were to be given to her for delivery from prison, which would allow her to be released for the "future day of her appearance." ${ }^{189}$ She then adds in the Vie that, "I see already accomplished in part what was then shown me." This clearly speaks to the fact that, by the time she wrote this passage, she had already given birth to the inner way of Guyonism, presumably by publishing and disseminating her writings, and that this "child" had been accepted by God on the throne as the only reality. Thus present in this one passage from Mme Guyon's autobiography (which was separated into parts in the above discussion for easier comprehension), were all

\footnotetext{
188 Guyon, Vie, 288.

189 Guyon, Revelation, 86.
} 
of the major elements of the woman of the apocalypse and her amazing story presented in the Book of Revelation.

Further evidence lies in the Vie which indicates Mme Guyon as the woman of the apocalypse. Reflecting on her commentary of Revelation, she writes, "here it was that I wrote upon the Apocalypse, and that there was given me a greater certainty of all the persecutions of the most faithful servants of God." ${ }^{190}$ From this statement, Mme Guyon seems to be indicating that she found consolation and kinship with the vision of the apocalypse as it pertained to her own life. Father La Combe had told Mme Guyon that she was "a stone which God designed for the foundation of some great building... His divine majesty will make use of me in this life, for some design known to himself only, or will make me one of the stones of the new and heavenly Jerusalem." ${ }^{191}$ Since the vision of New Jerusalem is taken from the Book of Revelation, and since the foundation of this city is to be found in the child of the woman of the apocalypse, the association of Mme Guyon with the "stones" of the coming Jerusalem is clearly indicative of her association with this queen of heaven. Further, Mme Guyon says multiple times in her Vie that she was destined by God to be the mother of his special children of inner prayer: "the Lord made it known also to many persons, that He designed me for a mother of great people, but a people simple and childlike." ${ }^{192}$ Later, she writes, "Also, I perceived the quality of a spiritual mother; for the Lord gave me what I cannot express for the

${ }_{190}^{190}$ Guyon, Vie, 349.
${ }_{191}$ Guyon, Vie, 227. 
perfection of souls." 193 "It was then that I comprehended the true maternity beyond what I had done before," Mme Guyon writes regarding the period of her life after consummation with Christ had been achieved, "for those of the latter kind ["plants to cultivate"] were given me as children." ${ }^{194}$ That the Lord 'impregnated' her with these children was not under question, for she writes, "our Lord would give me, by a spiritual fruitfulness, a great number of children." ${ }^{195}$ Thus, as these several examples indicate, Mme Guyon was recreating the vision of herself as the woman of the apocalypse throughout the writing of her autobiography.

As this chapter has argued, Mme Guyon considered herself the woman of the apocalypse, the true queen of heaven who would be beside her husband at the initiation of the new earth and new heaven predicted by the Book of Revelation. The first section provided general evidence of her saintliness, including her status above all others mystics and saints canonized by the Church. Following this, I discussed how Mme Guyon was carefully constructing herself a place alongside that of Jesus, as co-heir to the kingdom of God. This status was based on her position as his only bride, a concept which is reinforced by examining not only the basic Guyonist method of union with God, but also the portrayal of Jesus in Mme Guyon's writings. This examination cumulated

\footnotetext{
192 Guyon, Vie, 235.

193 Guyon, Vie, 279.

194 Guyon, Vie, 309.

195 Guyon, Vie, 315.
} 
with the assertion that, to her, Jesus was ultimately a spouse with whom she could have mystical sexual relations, and with whom she could bear legitimate children. Such a statement ties in directly with the evidence that Mme Guyon did consider herself this bride in the only fashion described by the Bible: the woman of the apocalypse. As the queen of heaven, and Jesus' only legitimate bride, Mme Guyon's children were thus the true descendants of Christ. The first child was the doctrine of the inner way, which would rule over all the nations, the other children, the totality of her followers, were to assist in the coming of Jesus and this inner way in the future. Together, these children would constitute the new church which would arise from the rubble of the Catholic Church - a new church based on Guyonist inner prayer, and established by her students whom she considered God's true children. 


\title{
Chapter 4 \\ Mme Guyon as Saint: Constructing the Autobiography
}

\author{
It is not to draw public approbation upon them, \\ that He makes them instrumental in the salvation of others; \\ but to render them to objects of their dislike and the subjects of \\ their insults; as you will see in this life you have enjoined upon me to write. ${ }^{196}$ \\ Jeanne Guyon speaking on writing the Vie
}

Here she left off her narrative, though she lived a retired life above seven years after this date. What she had written being only done in obedience to the commands of her director. ${ }^{19}$

Comments of Paul Poiret at the end of Mme Guyon's Vie

Madame Guyon, convinced that she was a living saint, made the necessary claims in order to convince others who might doubt her status that, indeed, it was true. To this end, she wrote her own autobiography without excuse. La Vie de Madame Guyon écrite par elle-même, referred to in this thesis as the Vie, has since gained obvious recognition as the finest source of information on its problematic and controversial author. Most of the autobiography was written during Mme Guyon's imprisonment at the convent of the Visitation of Saint Mary from January 1688 to August 1689 . So convincing is her voice that, since being published in 1720 , this work has been taken at face value, its contents unquestioned by readers. Her words are accepted as truth, and little analysis, if any, has been done as to the motivations and real meaning behind this text. Considering that Mme Guyon was a woman with a clear

\footnotetext{
196 Jeanne Guyon, An Autobiography: Madame Guyon, trans. Gene Edwards (Chicago: Moody Press, 1970), 18. For the purposes of this thesis, this work will be referred to in the footnotes and the text as simply the Vie (referring to the original title, La vie de Madame Guyon).
} 
purpose - to prove herself the earthly bride of Christ and a mortal saint - it is necessary to reinterpret her autobiography in this light. An analysis and close reading of the Vie does, in fact, provide this evidence. Mme Guyon was a woman with a purpose, who carefully and intelligently constructed her autobiography to reveal a life which could shatter all doubt of her true sanctity. She did, in effect, write her own hagiography with clear goals in mind, and for this reason, an acceptance of the Vie at face-value may yield a highly biased and perhaps incorrect vision of the late seventeenth century. This chapter discusses the circumstances surrounding the writing of the Vie, and concludes that it was a carefully constructed volume undertaken on Mme Guyon's own initiative.

Before I progress, a note on the bibliography of Mme Guyon's autobiography is necessary. Most of the three-volume work was written, as stated above, between January 1688 and August 1689 while she was imprisoned for heresy at St. Mary's Convent. At a later period, after her release from the Bastille in 1703, Mme Guyon must have returned to the manuscript, as most of the thin third volume discussed her meetings with Fénelon (October 1689), her discussions with Bossuet (mid-1693 and on), and briefly touched on her career as a prisoner in the late $1690^{\prime}$ s. The final entry in the book is dated December, 1709 , interestingly enough during a period when she was living unconfined at her son's estate in Blois. During this period before her death, Mme Guyon entertained several Protestant and Puritan leaders from England and the

${ }^{197}$ Guyon, Vie, 382. 
Netherlands, and it is likely that one of them expressed an interest in publishing the autobiography (which had only been previously circulated as copies of the original manuscript). Upon her death in 1717, Paul Poiret, an acclaimed Puritan leader, must have taken a copy of the manuscript with him to Amsterdam. It was there in 1720 that he published it, in three small volumes, with a preface written by himself introducing each section. These volumes were republished in France by Dutoit in 1791, and it is likely that the copies of the Vie circulating today are based on this later printing. ${ }^{198}$ For this thesis, I have examined several copies, in English and the original French, of Mme Guyon's Vie, and have chosen to use a recently updated version published by Gene Edwards for the Christian Seed Sowers Press because of its excellent translation. All references throughout this thesis, thus, refer to this thick English volume.

Like many saints' lives, the Vie of Mme Guyon opens with an explanation of her intentions in writing such a piece. In the first chapter, she explains that her goal is "to paint in true colors the goodness of God to me... but it is impossible, as numerous little circumstances have escaped my memory." ${ }^{199}$ This seems a common enough modesty topos, used by writers for centuries to explain away any mistakes in the work as being the fault of a forgetful author. The first chapter continues with a similar tone, the words being directed to an unidentified "you." She says:

\footnotetext{
${ }^{198}$ Marie-Louise Gondal discusses the extant editions of the autobiography in the original French, claiming that these are the only two printings before the 1960's. See the annotated bibliography, section 3. ${ }^{199}$ Guyon, Vie, 13.
} 
I willingly comply with your desire, in giving you a more circumstantial relation.... You are also unwilling I should give you a minute account of my sins.... I depend on you to destroy it, when your soul hath drawn those spiritual advantages which God intended, and for which purpose I am willing to sacrifice all things. I am fully persuaded of His designs towards you, as well as for the sanctification of others, as for your own sanctification. ${ }^{200}$

Mme Guyon's Vie begins as any autobiographical saint's life, stating that she was writing for the benefit of those who wished to understand how such a holy woman came to be. Indeed, it is clear from this passage that she is a prophet of God, as she has been told not only that the one whom she is writing for is beloved, but predicts the forgiveness of others' sins as well. Amazingly, but not surprisingly, the modesty topos of her introduction becomes intertwined with self-admiration, as she admits God is speaking to her. But the most intriguing question of this introductory chapter is: just who is she addressing? Who is this "you?"

This question of who she is speaking to in the first chapter is crucial. There are two plausible answers: a confessor, or God himself. The statement -"I am fully persuaded of His designs towards you" - indicates that God was not the one who originally instructed her to write the autobiography. The wording of this line implies that a person told her to compose the Vie, a person whom God had directed towards Mme Guyon, and whom she had been told to trust. The exclusion of God as the source for the autobiography prevents Mme Guyon's Vie from imitating esteemed saintly writings which confirmed God as their

${ }^{200}$ Guyon, Vie, 13. 
inspiration. The Confessions of St. Augustine, a well-known work throughout western history, is an example of this form of hagiography. This is not to say that Mme Guyon does not address God in the Vie. On the contrary, there are two "yous" in this work: the introductory chapter "you" whom she credits, as shown above, with instructing her to write the autobiography, and the "you" in the prayers she makes in every chapter to God. Mme Guyon does not address the first individual - the first "you" -- beyond the introductory chapter, nor does she explain any further her motivation for writing such a text. The question, then, of who instructed her to put her life story on paper remains.

Many scholars naturally assume that, like most saints of the past, Mme Guyon was speaking to her confessor, who in turn must have directed that her story be told. This is not an uncommon practice for autobiographies by Catholic saints. St. Teresa of Avila was instructed to write about her life by her confessor, Father García de Toledo in 1562, and completed it three years later. ${ }^{201}$ Angela of Foligno dictated her story to Brother Arnaldo in the 1290's. The Beguine, St. Gertrude the Great, wrote her autobiography under the direction of a confessor; this priest, in turn, wrote a biography about her after her death in $1291 .{ }^{202}$ Certainly, the composition of one's own story was not an unheard of command by confessors to their penitents.

\footnotetext{
${ }^{201}$ See the introduction and chronology to St. Teresa of Avila, The Autobiography of St. Teresa of Avila, trans. E. Allison Peers (Garden City, NY: Image Books, 1960).

${ }^{202}$ More details on saints and mystics who have written their own autobiographies can be found in Elizabeth Petroff's Medieval Women's Visionary Literature (New York: Oxford University Press, -1986).
} 
The initial concern for the historian examining this autobiography is that, unlike the lives of other saints whom she was emulating, no one specifically asked her to write it. As stated, although she seems to be addressing a specific cleric at the beginning of the text, possibly Father La Combe, there is no real evidence that he or anyone else ever asked her to construct such a piece. In her biography entitled Madame Jeanne Cuyon: Child of Another World, author Dorothy Gawne Coslet asserts the general opinion of scholars when she states that, "it was here at Saint Mary's Convent that she started writing her autobiography, a task which her spiritual director had assigned to her." ${ }^{203}$ Several points must be raised regarding this statement by Coslet. Mme Guyon is very careful not to mention, as the autobiography unfolds, just exactly who her official confessor was at any one moment. Indeed, reading the autobiography from cover to cover reveals that, at the time of her imprisonment in 1688 , she may have not had a confessor at all.

Father La Combe had been her confessor for some time before her stay at St. Mary's. In the Vie, an entry regarding her arrival in Gex in 1681 states that the Bishop of Geneva assigned La Combe to her as a confessor: "After I had spoken to him [The Bishop of Geneva], he said that he had it in his mind to give me Father La Combe for director.... Greatly, was I rejoiced when the Bishop appointed him...." ${ }^{204}$ Thus, in 1681, La Combe became her confessor as appointed by the Church. This issue becomes problematic, then, in trying to

${ }^{203}$ Dorothy Gawne Coslet, Madame Jeanne Guyon: Child of Another World (Washington, PA: Christian Literature Crusade, 1984), 122. 
establish whose idea her autobiography really was: hers, or her confessor's. La Combe was arrested and placed in the Bastille as a heretic in 1686. By the time of her imprisonment in late January 1688, La Combe was out of sight and she was not speaking or corresponding with him. After La Combe was arrested, Mme Guyon alluded to the fact that she fell under persecution because, as a Catholic, she no longer had a confessor. Her search began for another in order to legitimize her activities, which had already been scrutinized as being heretical. Her brother, the respected Father La Mothe, offered to be her confessor (and perhaps her savior) upon the arrest of La Combe, but she refused this by saying, "They [various Church officials headed by the Archbishop of Paris] wrote to me that... I should put myself under the control of Father La Mothe... that I was mad and ought to be bound; and was a monster of pride, since I would not suffer myself to be conducted by Father La Mothe." ${ }^{205}$ By the time she began the Vie in 1688, neither La Combe nor La Mothe were acting as her confessor. This is an important point, for who could have known her better than these two men, one of whom she considered to be her best disciple, and the other of whom was her greatest persecutor (not to mention her brother)?

More evidence comes to bear in this investigation. When she was jailed at St. Mary's on January 29, 1688, the guards assigned to watch her asked who her confessor was. She reports in her Vie that, "I named him [the confessor]; but he was seized with such a fright that he denied it; though I could have produced

\footnotetext{
${ }^{204}$ Guyon, Vie, 233.

${ }^{205}$ Guyon, Vie, 361-362.
} 
many persons who had seen me at his confessional." ${ }^{206}$ The reader of her autobiography is never told who this person is, and it is doubtful that, considering the controversial aspect of her person at the time in Paris, anyone would have accepted such a task. More interesting is the next sentence, which reads, "So then they said that they had caught me in a lie; I was not to be trusted." ${ }^{207}$ Was she caught in a lie because the confessor refused to speak, or because she had no confessor at all? This point is crucial, as the entire autobiography was written, as mentioned before, as though she was writing on the direct command of a spiritual confessor. Yet, as has been shown, by the time she had begun writing she either had no confessor, or had one who refused to acknowledge his relationship with her.

It appears that Mme Guyon wrote the autobiography under her own direction: she was inspired with the idea and penned it under her initiative alone. The reasons for her having done so were none other than the emulation of previous saints' lives and because she had an important point to convey, namely that she was the true Queen of Heaven. Bypassing the fact that neither God nor a confessor directed her to do so, while at the same time embracing the notion that she was a living saint, Mme Guyon sought to copy the saints of the past by writing her own life story. In this way, she sought not only to frame her unquestionable holiness and sanctity as Christ's chosen one, but also to ensure that future Catholics would look upon her as such. Mme Guyon may have been

\footnotetext{
${ }^{206}$ Guyon, Vie, 364.

207 Guyon, Vie, 364.
} 
writing about herself to justify her current position, and to disguise any misdeeds which could have been interpreted as non-saintly. I must add that writing her own story was not the action of a stupid, uneducated woman, as many have called her. The composition of this hagiography was an intentional, conscious effort on her part to justify her position as the woman of the apocalypse. It was, in sum, a clever, highly ingenious action on her part. ${ }^{208}$

208 Those who have accused Mme Guyon of being ignorant, uneducated, and crazy (among other things) include her contemporary le duc de Saint-Simon, Voltaire, and as has been shown, Bossuet. 


\section{Chapter 5 \\ Mme Guyon as Saint: Autobiography as Hagiography}
The gospel effectually in this point shows itself to be true, which has promised to those that shall leave all for the love of the Lord, "an hundred fold in this life, and persecutions also." And have not I infinitely more than an hundred fold, in so entire a possession as my Lord has taken of me; in that unshaken firmness which is given me in my sufferings, in a perfect tranquility in the midst of a furious tempest, which assaults me on every side; in an unspeakable joy, enlargedness and liberty which I enjoy in a most straight and rigorous captivity. ${ }^{209}$ Jeanne Cuyon from prison, 1688

I prayed to the Lord to be pleased to grant a wind to rise, to moderate the violent heat. Scarce had I prayed, but there arose suddenly so refreshing a wind, that I was surprised and the wind did not cease during [our] whole journey. ${ }^{210}$ Jeanne Cuyon reflecting on the journey to Ceneva, 1680

The autobiography conceived by Mme Guyon in 1688, and finished in 1709, appears a hagiography with a motivational self-bid for future, if not immediate, canonization and immortalization. As argued in the last chapter, it was through her own initiative that the project was undertaken in order to achieve a very specific goal, namely to provide detailed and unquestionable evidence that she was the woman of the apocalypse. This chapter examines the autobiography closely in order to retrace the efforts of Mme Guyon to write her own history. In order to succeed in my analysis of Mme Guyon's Vie as a hagiography, I have chosen to present the evidence according to a three-part chronology which corresponds closely with this autobiography: her childhood, her marriage, and her widowhood. I will not discuss the period of time past the

\footnotetext{
${ }^{209}$ Jeanne Guyon, An Autobiography: Madame Guyon, trans. Gene Edwards (Chicago: Moody Press, 1970), 210. For the purposes of this thesis, this work will be referred to in the footnotes and the text as simply the Vie (referring to the original title, La vie de Madame Guyon).
} 
initial writing of the Vie in 1688 , as a review of these three periods in her life will suffice in showing that she was constructing herself as a living saint. ${ }^{211}$ I will employ the characteristics of saints in the following discussion, whereby concentration on Mme Guyon's autobiography concerns the following topics: the power and influence of saints, gained by teaching her doctrine; the performance of daring and immoderate things, such as embracing extreme poverty and performing miracles; and the strong emphasis placed on her mortal struggle, as seen through excessive persecution, illness, and personal grappling with sin. In the Vie, Mme Guyon attempts to reconcile three major themes: her refusal of a Christ-like lifestyle, her complaining about suffering offenses, and her constant rebuttal of slander against her. Mme Guyon endeavors to mimic the requirements of sanctity by accentuating them, or creating them outright, in order to show that she was poor, meek, and humble - all traits which would be expected from one who was united constantly with God and who was free from self-love. Overall, this intense discussion devoted to the autobiography of Mme Guyon seeks to show that the text was written as a hagiography, and did not necessarily represent an accurate, truthful rendering of her life.

\footnotetext{
${ }^{210}$ Guyon, Vie, 212

211 As well, the period of the autobiography dating past 1688 was written sometime in the late 1690 's and early 1700's, placing it out of range of the original manuscript. This discussion, which tells of the factors leading to the Quietist Controversy, has been examined in detail already in chapter two of this thesis.
} 
As the quote opening this thesis asserted, Mme Guyon was born into a family of saints. ${ }^{212}$ Her birth was a miracle in itself, as her mother had a spontaneous abortion in her eighth month of pregnancy. Although written off as dead at birth, she amazingly managed for two and a half years to struggle against expiring so that "they [her parents] could find a proper opportunity to baptize me." During her early years, Mme Guyon claims that she was chosen by God as his special child, and was given gifts of courage and strength that were "an uncommon matter" for someone so young. ${ }^{213}$ What is most intriguing is that Mme Guyon wishes to convey that she had been given the gift of inner prayer at a very early age. Upon reading the works of St. François de Sales at five or six, she recognized that his method of mental prayer was very similar to that which she already had been practicing. However, Mme Guyon expresses that the reason she did not achieve union with God at this time was because she was faulty in her prayer: "I used my own endeavors to practice it, though without success, as I then thought, because I could not exercise the imagination, I persuaded myself, that that prayer could not be made without forming to one's self certain ideas and reasoning much." ${ }^{214}$ This minor frustration did not hold her back, nonetheless, from desiring to live piously. Little Jeanne was even willing to die as a martyr at age five, when she was so inspired by love of God that she prepared herself to be beheaded. She writes of this incident:

\footnotetext{
${ }^{212}$ Guyon, Vie, 19. I will only make a footnote for those passages which are not on the same page as the one before them for the remainder of this chapter.

${ }^{213}$ Guyon, Vie, 21.

${ }^{214}$ Guyon, Vie, 36.
} 
The good girls of the house [a Benedictine convent], to amuse themselves, and to see how far this growing fervor would carry me, desired me to prepare for martyrdom. I found great fervency and delight in prayer, and was persuaded that this ardor, which was as new as it as pleasing, was a proof of God's love.... Being placed kneeling on a cloth spread for the purpose, and seeing behind me a large sword lifted up which they had prepared to try how far my ardor would carry me, I cried, "Hold! It is not right I should die without first obtaining my father's permission."... I was no longer a martyr. I continued long disconsolate... something inwardly reproved me, for not having embraced that opportunity of going to Heaven. ${ }^{215}$

This passage signifies a major step in Mme Guyon's youth, as after this point she supposedly gained even more religious fervor. What is interesting about this incident, though, is that she does not scorn the girls who did this to her, nor does she seem to be at all hesitant about where her five-year-old soul was going after death. These are two themes which permeate the manuscript of her Vie, signifying her attempt to look humble against those who scorn her, and her constant, unwavering belief that she was going to heaven.

As the autobiography continues in its description of her youth, the reader (and there can be no doubt that Mme Guyon intended her story to be read by a large audience) is told of the overabundance of outstanding qualities which God bestowed on her. Her life, even as a child, was being carefully directed by the hand of the Lord. Upon speaking of her sister becoming her tutor, she says, “This was a singular dispensation of God's providence and love toward me... her affection made her discover in me many amiable qualities, which the Lord had implanted in me." ${ }^{216}$ Not only that, Jeanne had an outstanding intelligence, and

\footnotetext{
215 Guyon, Vie, 21-22.

${ }^{216}$ Guyon, Vie, 25.
} 
was known for her abilities to defeat adults in trivia games: "Many grown persons of rank could not have answered the questions." ${ }^{217}$ Being a chosen one of God meant that she was also exceedingly religious as a child, and Mme Guyon devoted a large section of her early autobiography to describing her saintliness as a young girl. She writes, "I loved much to hear of God, was not weary of church, loved to pray, had tenderness for the poor, and a natural dislike for persons whose doctrine was judged unsound." ${ }^{218}$ While other children, we are told before this sentence, were busy playing and thinking of worldly matters, Jeanne was reading her Bible and begging confessors to see her. The final part of this passage is striking, as it seeks to confirm that she was imbued with an automatic dislike for heresy. She maintains this thought by saying, "God has always continued to me this grace, in my greatest infidelities." Due to an innate distaste for that which was "unsound," she naturally could not be attracted to it in any way, and her doctrine of the inner way could not be opposed to the desires of the Lord.

Along a similar saint-inspired tone, as a young girl Jeanne fell in love with the story of St. Jeanne de Chantal, and often wished that she could emulate her heroine. As a teenager, St. Chantal had burned the name of Jesus upon her skin with a hot iron. Mme Guyon explains that, desiring as well to have a mark of Jesus, she wrote his name on a piece of paper and ingeniously decided to sew it to her skin with ribbon. "In that position," she says, "it continued a long

\footnotetext{
217 Guyon, Vie, 26.
}

${ }^{218}$ Guyon, Vie, 26-27. 
time. ${ }^{\prime 219}$ This is one of the first clues that Mme Guyon might be constructing her autobiography to meet a carefully defined goal. While we are led to believe that this method of self-mortification was one she invented, indeed this is not true.

Other mystics, most notably St. Catherine of Siena, performed a similar action. ${ }^{220}$ Could it be that Mme Guyon was telling the truth, purposefully leaving out her true sources of inspiration? Or is it that she needed this inspired idea in order to place herself among the admired mystics of the past in order to justify her own teachings? Considering this, it becomes even more apparent how Mme Guyon was beginning to build her youthful self as someone of outstanding and mature piety, whom God was preparing for the future.

Despite all of her outstanding qualities, Mme Guyon describes her childhood as a time of constant torture and grievances. The first dozen or so chapters of the Vie describe Jeanne as bullied and slandered by almost everyone, including her siblings, family servants, nuns, fellow children and mother. She says of this period that, "Everything seemed to punish me." 221 Of the numerous instances sprinkled heavily throughout these early pages, a few examples will show the extent to which Mme Guyon thought herself a constant victim of injury. Speaking about her cousin she said, "He knew that some young ladies had, out of envy, traduced me and that I spoke well of them as occasion

\footnotetext{
${ }^{219}$ Guyon, Vie, 37.

${ }^{220}$ We know that Mme Guyon had read St. Catherine of Siena extensively by the late 1680's, as she confirms having knowledge of this saint and many other mystics in herJustifications.

${ }^{221}$ Guyon, Vie, 32.
} 
offered." 222 Her brother (the future Father de La Mothe) would beat and abuse her incessantly: "One day he made me mount the top of the coach; then threw me down.... At other times he beat me." ${ }^{223}$ The girl who did her hair would strike her; her mother would become jealous if she spent time with other persons in the family, and would slander Jeanne to her father, to which he would respond, "There are twelve hours in the day; she'll grow wiser." 224

A good portion of this persecution was caused by her extraordinary beauty. By the time she was eleven Jeanne felt that the splendor of her face and body made her the jewel of the family. Her mother took an enormous amount of pleasure in displaying her in fancy dresses, taking "inordinate pride in that beauty which God had formed me, to bless and praise Him." ${ }^{225}$ This obsession with her own loveliness, bestowed on her as a gift of God, might have led her immediately to vanity and pride as a young teenager, but she turned down several suitors by the age of twelve, and instead "loved reading" and would shut herself "up alone every day to read without interruption." Eventually, however, this great beauty won out over her love of God, and she fell into a pit of sin, which brought more reproaches on her from friends and family.

These endless persecutions, combined with constant illnesses, were meant to be signs from God that she was His chosen one. She writes that all

\footnotetext{
Guyon, Vie, 40.

Guyon, Vie, 30.

Guyon, Vie, 32.

Guyon, Vie, 33.
} 
these trials were meant to force her into the inner way of prayer which she had been toying with since a tender age:

O my God, thy grace seemed to be redoubled in proportion to the increase in my ingratitude! It was with me as with a city besieged, Thou didst surround my heart, and I only studied how to defend myself against thy attacks.... I closed up the avenues of my heart, that I might not so much as hear that secret voice of God, which was calling me to Himself. ${ }^{226}$

In this passage Mme Guyon asserts that God had called her to be persecuted, both externally and internally, at a young age in order to expedite her movement towards union with Him. In writing that she calmly accepted the manner in which others abused her verbally and physically, she casts her $1680^{\prime}$ s spiritual beliefs on her childhood. She says during a discussion of these childhood persecutions in chapter four that:

There are persons who think themselves very mild because nothing thwarts them.... Mildness which has never been put to the proof is often only counterfeit. Those persons who, when unmolested, appear to be saints are no sooner exercised by vexing occurrences than there starts up in them a strange number of faults. They had thought them dead which only lay dormant because nothing awakened them. ${ }^{227}$

She does not want anyone to think that, chosen by God from birth to be his bride, she harbored foul or malicious thoughts against those who persecuted her. Those persons who were mild, as this passage confirms, were so usually because their peace of mind had never been contested. Therefore, it was necessary for her to prove that she was in fact challenged as a youth, and that the mildness which she displayed as an adult was not "counterfeit." However, in 
the first passage she laments that she responded to this condemnation, it can be assumed, by lashing back (defending herself against the attacks) instead of accepting it cheerfully and modestly. My assertion here contradicts former examples given above where Mme Guyon claims to have held no bad feelings for those scorning or beating her. If this were indeed true, then why would she regret her behavior in regards to these incidents? Those who follow the inner way are supposed to turn a cheek to their slanderers. Mme Guyon was attempting to rebuild her childhood when she wrote the Vie, but she missed this inconsistency, or rather became confused about how to handle conflicting goals.

There was good reason for her disorientation. When the events of her childhood are examined closely, it appears that Mme Guyon was trying to construct an image of an innocent creature who fell into evil. She is presented with all good traits - beauty, virtue, kindness, charity, intelligence - in order to emphasize her fall. This might seem immediately contrary to the goal of this thesis, which is to show that Mme Guyon thought of herself as a living saint. However, it was necessary for her to be a sinner, in some way, to justify her later life. It is interesting that, when choosing which of these traits she would discredit, she chooses that of beauty. Mme Guyon tells how she became tremendously vain, and slowly began to forsake her spiritual growth in order to be seen in public. She writes, "This spirit [of prayer] gradually decayed, not being nourished by prayer. I became cold toward God. All my faults [namely lying] revived to which I added an excessive vanity. The love I began to have for

${ }^{227}$ Guyon, Vie, 35-36. 
myself extinguished what remained in me of the love of God." ${ }^{228}$ Several more pages tell of the horror of her (mostly undescribed) sins:

I became still more passionate than I had ever been, as age gave more force to nature. I was frequently guilty of lying. I felt my heart corrupt and vain. The spark of divine grace was almost extinguished in me, and I fell into a state of indifference and indevotion... I began to pass a great part of my time before a looking glass. I found so much pleasure in viewing myself, that I thought others were in the right who practiced the same.... All seemed to me to look beautiful in my person, but I saw not that it covered a polluted soul." 229

Mme Guyon describes herself at thirteen and fourteen as a great sinner because of her lying and self-love. This is not exactly how one expects a saint to behave, especially one who, as exemplified above, was given so much favor by God at birth. However, the enigma of this situation soon shows itself, for a major requirement of Guyonist prayer is that one must have sinned excessively in order to attain union with God. This assertion is shown in her Moyen court, in which she specifically calls to sinners to follow the inner way of prayer. ${ }^{230}$ Her essay Spiritual Torrents conveys a similar message: "But those believers who consider themselves good because they have not known many weaknesses have many problems, too.... Remember, your Lord makes His mercies abound where sin has abounded."231 Sinners have the better possibility of union with God because they are not self-righteousness, because they know they have sinned. Therefore, by attributing sins to herself as a youth, she prepares for the description of her own conversion. If Mme Guyon had not been a sinner in her youth, she would

\footnotetext{
Guyon, Vie, 41.

29 Guyon, Vie, 44-45.

230 Guyon, Experiencing, chapter 1.
} 
have necessarily been self-righteous and thus unable to achieve union with God. Sin is necessary to travel the inner way, for she tells us, "you will never know the center of God by an exalted view of yourself." Thus, returning to the argument which opened this paragraph regarding the inconsistency of Mme Guyon's view of sin and humility, it is clear that she must sin (by lashing out at her critics with lies or flaunting her beauty), but she also must assert her acceptance of persecution with a turned cheek. Such conflicting views make the first chapters of her autobiography difficult to understand, but prove nonetheless that she was pining over how to frame her life with specific goals firmly in mind. Her vanity increased when the family moved to Paris in 1663 , and she says "I wanted to be loved of everyone and to love none." ${ }^{232}$ However, her father arranged a marriage contract with a man whom she had never met, and this free-loving young woman decided to settle down without even reading the nuptial agreement. Mme Guyon writes, "I was well pleased with the thoughts of marriage, flattering myself with a hope of being thereby set at full liberty, and delivered from the ill-treatment of my mother which I drew upon myself." 233 This was the same woman who had written only a few pages earlier that, "I turned all my thoughts to become a nun." ${ }^{234}$ And, indeed, after we are told of her joy at becoming engaged, Mme Guyon claims, "the joy of our nuptials was universal through our village. Amid this general rejoicing, there appeared none

\footnotetext{
${ }^{231}$ Guyon, Spiritual Torrents, 23.

${ }^{232}$ Guyon, Vie, 49.

${ }^{233}$ Guyon, Vie, 50.

${ }^{234}$ Guyon, Vie, 37.
} 
sad but myself. I could neither laugh as others did, nor even eat; so much was I depressed.... The remembrance I had of being a nun came pouring in.... I wept bitterly." ${ }^{235}$ Thus, it never is truly clear if she was happy or sad at being married, but she soon turns the situation into a sign from God that she should stop sinning (at least through her vanity) and return to mental prayer. It was through the staining of her person caused by consummating her marriage that Mme Guyon truly was brought into God's hands. Mme Guyon, adamant that $\sin$ is required in order to achieve union with God, requires that virgins cannot travel the inner path to the Lord. Again quoting from Spiritual Torrents, "Take, for instance, the virgin, or someone who has taken chastity as a vow. Be careful that you do not make purity your idol. Remember, your Lord makes His mercies abound where sin has abounded. Be careful that you do not love your own righteousness." ${ }^{236}$ What is thus apparent in the autobiography is that Mme Guyon justified the actions in her past as being directed by God for the sole reason of bringing her to Him. God saved her from vanity, her great sin, by making her marry. He also made her impure by placing her in the context of conjugal love, whereby Mme Guyon was given the opportunity to denounce many sequestered mystics before her as never having achieved union with God because of their virginal condition; because she was united with God, and she had lost her virginity, those who aspired to a similarly elevated position must also have had sexual relations. This experience of sin and marriage was given to

\footnotetext{
${ }^{235}$ Guyon, Vie, 51.

236 Guyon, Spiritual Torrents, 23.
} 
her by God so that she would be able to understand others, her future disciples, more clearly: "Oh, how much compassion has this sad experience given me for sinners." ${ }^{237}$ It also is not unusual, as I pointed out in chapter three of this thesis, for Catholic saints to be married; thus, this decision does not seem to haunt her consciousness as a factor potentially preventing canonization. All of her actions, or life experiences, become the will of God in order to draw her (his chosen one) closer to him and in order to prepare her to do his bidding in the future.

Having placed her in this context by which her ability to sin would be impaired, her marriage to Jacques Guyon becomes the ultimate path to her conversion and union with God. This period of her life as a wife, which lasted from 1664 to 1676 , constitutes at least half of the autobiography; I will attempt to draw general conclusions about this period rather than work through it in a chronological matter. The years of her marriage were some of the most crucial in her life, for it was during this time that she realized she was the chosen bride of Christ. There are three themes in the Vie the discussion of which will summarize the entire period: her crosses increase as she was struck with excessive persecution and devastating illnesses; she converted to the inner way and achieves union with God; and she continued to grow in grace, humility, and charity. As will be shown, Mme Guyon's Vie creates a picture of herself as a living martyr, everwilling to die from her extreme crosses, but saved each time by her heavenly spouse, who needs her to give birth to his 'male child,' or inner prayer. The theme of living martyrdom is further confirmed by the persecution 
she withstood because of her conversion to the inner way, and also because of her increasing purity. All of these factors were proof of the miraculous increase in God's grace and the subsequent perfection of her person. The result of this study will show that by the time of Jacques Guyon's death in 1676, she had, in her own mind, reached the status of living saint.

Mme Guyon's marriage can best be described as twelve years of incessant persecution. In fact, everyone who came into her life chastised her at some point: her mother-in-law, her husband, her children, her servants, her confessor, and her few friends. This strife is exemplified in many forms, including slander, physical abuse, demeaning comments, and the fact that Mme Guyon had to perform "the most humiliating offices." ${ }^{238}$ Immediately upon her entrance in the Guyon household, Mme Guyon (senior - M. Guyon had died before his son married) attacked her new daughter-in-law viciously. Mme Guyon writes, "I was made the victim of her humors. All her occupation was to thwart me and she inspired the like sentiments in her son." 239 Her waiting woman began to plot with Mme Guyon (senior) against her, and even the footmen persecuted Mme Guyon upon her arrival at the Guyon house: "When I went out, the footmen had orders to give an account of everything I did. It was then I began to eat the bread of sorrows, and to mingle tears with my drink." ${ }^{240}$ The crosses (as she calls the many incidents of persecution or troubles) continued to escalate in severity, and included her husband's inability to work due to severe gout, and the birth of her

\footnotetext{
Guyon, Vie, 52.

${ }^{239}$ Guyon, Vie, 52-53.
} 
first child. Mme Guyon says, "my crosses redoubled. What rendered them more painful was that my mother-in-law, not content with the bitterest speeches which she uttered against me, both in public and private, would break out in anger about the smallest trifles, and scarcely be pacified for a fortnight." ${ }^{241}$ Such severe persecution persisted throughout her marriage to Jacques Guyon, but Mme Guyon realized a few years into this earthly union that such harsh mistreatment was a sign of her Chosen status.

Being in such a difficult situation, it would be natural to assume that Mme Guyon responded with an equal amount of anger and rapprochement. However, this was not the case, as she informs us that:

Being kept with such persons, in a most severe confinement, from morning till night, without ever daring to quit them is most difficult. I have found that great crosses overwhelm, and stifle all anger... It was such strange effect, that it requires the utmost efforts in self-restraint, not to break out into vexation and rage." ${ }^{242}$

Mme Guyon discovered that the constant caviling she received from her motherin-law, husband, and others was sent to her by God in order that she loose all self-love and self-interest. This harkens back to the requirements established by Mme Guyon on the inner path to the Lord, which include calmly withstanding severe persecution in order to prove one's worthiness for union. The figure of the pregnant woman of the apocalypse being tormented by the dragon can be summoned to further explain why torment on an intemperate level was

\footnotetext{
240 Guyon, Vie, 54.

${ }^{241}$ Guyon, Vie, 56.

${ }^{242}$ Guyon, Vie, 57.
} 
necessary in these chapters of the Vie. Mme Guyon accepted these crosses with joy, and began to act in the most pious matter.

The married life of Mme Guyon was one in which she was truly seemed to transform into a saint: "Thou, O my God, increased both my love and my patience, in proportion to my sufferings." ${ }^{243}$ God also sent her a sign in the form of a priest who, upon seeing her for the first time, told her that God had Chosen her to do His will. Upon her next meeting with this unnamed priest, he told Mme Guyon that while he was praying God said to him: "Fear not that charge [of becoming her confessor]; she is my spouse." ${ }^{244}$ After this incident, which occurred sometime in the late 1660 's, Mme Guyon was well on her way to union with God. She was no longer capable of sinning, and her senses were "continually mortified" ${ }^{245}$ The Lord began to correct all faults in her personality, and gave her the ability to automatically censure her actions, thoughts, and words. Mme Guyon writes:

Divine love so enlightened my heart, and so scrutinized into its secret springs, that the smallest defects became exposed. If I was about to speak, something wrong was instantly pointed out to me, and I was compelled to silence.... When I walked, I observed that there was something wrong; if I spoke in any way in my own favor, I saw pride.... Pure love always found matter for reproof in me, and was jealous that nothing should escape unnoticed. ${ }^{246}$

In this passage, God carefully forms Mme Guyon into the faultless bride, the one who would carry His child of truth (the inner way) and release it out into the

\footnotetext{
${ }^{243}$ Guyon, Vie, 68.

244 Guyon, Vie, 74.

${ }^{245}$ Guyon, Vie, 84.

${ }^{246}$ Guyon, Vie, 86.
} 
world. According to her, all imperfections, even the tiniest ones, which could go unnoticed, were being removed from her; the result was perfection. All of the crosses which she suffered were a sign of this process. "Indeed, the manner in which He corrects His chosen, must be felt, or it is impossible to conceive how dreadful it is." 247 This theme is apparent throughout the Vie, and is crucial in reconstructing the path of her self-canonization, for by a careful presentation of this evidence, Mme Guyon confirms her position in the $1680^{\prime} \mathrm{s}$ as a living saint.

In the midst of this persecution Mme Guyon also describes the years of her marriage to Jacques Guyon as being riddled with severe illnesses, all sent to further test her faith and purify her spirit. She writes that "no creature could be more heavily laden with sickness than I was." ${ }^{248}$ Many of these illnesses were considered to be tests by God of her faith, as Mme Guyon considered them additional forms of crosses she had to endure due to her status as chosen one. In order to purify her spirit, and rid Mme Guyon of any imperfections, the Lord took away all things that could lead her inadvertently into sin. The finest example of this mentality was in 1670 , when she contracted smallpox. Mme Guyon writes:

I had violent pains for three weeks during which time I got little sleep.... All that saw me said that they had never seen such a shocking spectacle. But as to my soul, it was kept in a contentment not to be expressed. The hopes of its liberty, by the loss of that beauty, which had so frequently brought me under bondage, rendered me so satisfied, and so united with God, that I would not have changed my condition for that of the most happy prince in the world. ${ }^{249}$

\footnotetext{
Guyon, Vie, 87

Guyon, Vie, 61.

${ }^{249}$ Guyon, Vie, 117.
} 
As she writes here, contracting smallpox was a gift from God to rid her of what she considered her greatest fault: exceptional beauty. In this way, illness became a tool of the Lord to make sure that his bride was sufficiently prepared for her coming role. It would seem that many of these illnesses were, however, attempts on her part to gain attention from her family, and she admits to having faked sickness several times. During the pregnancy of her first child, Mme Guyon says that she "had the malice to fake a cholic, to give them some alarm." ${ }^{250}$ This passage may indicate that Mme Guyon not only feigned sickness to get attention from her earthly family, but from God as well; after all, since her marriage to Jacques Guyon she had gone through a process of soul-cleansing. God, looking into her soul for the faults present there, might have been further induced to visit her and purify her spiritually because of this obvious deception. This tactic, however, was not successful for very long, and several years into her marriage her husband and mother-in-law would come to her bed to quarrel with her. Mme Guyon states, "If I fell sick, which often happened, they took the occasion to come to quarrel with me at my bed...." ${ }^{251}$ They learned of her deception because, she claims, God desired to absolve her of all faults, and because he also wished for her persecution to continue. By having her family accost her in weak moments of illness, or feigned illness, God brought the cross of condemnation to its greatest height.

\footnotetext{
250 Guyon, Vie, 61.

${ }^{251}$ Guyon, Vie, 122.
} 
Mme Guyon had been persecuted physically and mentally, and she had been victim to perpetual ailments, both trials which further justified her position (to herself, at least) as God's chosen one. However, the true rationalization of this status was confirmed after she outwardly expressed the conversion to inner prayer a few years after being married. While the exact moment and circumstances are vague, by 1666 or so, Mme Guyon claims she was moving towards union with God. This progress, during which she was being cleansed of her faults, was shown to others due to her growth in humility, charity, and peaceful disposition. Such outward expression, she writes in her Vie, was immediately met with criticism from those around her. The incident of smallpox (discussed above) was a sign, her mother-in-law and husband said, that her method of prayer was causing her illness: "They spoke as if there had been nothing else could make me ill, but my devotion to Thee, O my Beloved!" 252 The persecution by her family of her inward prayer continued until, sometime in the early 1670's, they forbid her from it altogether. Mme Guyon writes that, "all my crosses to me would have seemed little, if I might have had the liberty to pray, and to be alone, to indulge the interior attraction which I felt. But I was obliged to continue in their presence, with such a subjection as is scarcely conceivable." ${ }^{253}$ She also says:

I dared not go out from my mother-in-law's room, or from my husband's bedside. Sometimes I carried my work to the window, under a pretense of seeing better, in order to relieve myself with some moment's repose. They came to watch me very closely, to see if I did not pray instead of

252 Guyon, Vie, 122.

253 Guyon, Vie, 126. 
working. When my husband and mother-in-law played cards, if I did turn towards the fire, they watched to see if I continued my work or shut my eyes. If they observed I closed them, they would be in a fury against me for several hours. ${ }^{254}$

Mme Guyon, according to her Vie, was condemned for her method of prayer, but this criticism and close supervision seems to have been due to the general malice of her mother-in-law and husband, rather than for their concern that she was behaving in any way contrary to accepted Catholic prayer. Upon speaking to her one day about her prayer, Jacques Guyon said to his wife: "'you love God so much, that you love me no longer. ${ }^{\prime \prime 255}$ Thus, Mme Guyon's attention to prayer and movement towards union with God was seen as rather an obstacle for her husband, and her heavenly spouse was viewed as one competing with the earthly one for love and attention. This was further evidence, she asserts, that God had chosen her as his bride, for M. Guyon did not comprehend "that the true conjugal love is that which the Lord Himself forms in the heart that loves Him." This passage confirms that not only did she choose the Lord's proposal of marriage over M. Guyon's, but that true love in marriage only comes to those who the Lord chooses as spouse. Persecution then resulted necessarily from jealousy and greed on the part of her husband, who was inspired by God as well to condemn his wife so that she might be cleansed of her faults. Overall, the disapproval of the Guyon family for her inner prayer was just another cross to bear, and just another proof that she was special to God.

\footnotetext{
Guyon, Vie, 95-96.

${ }^{255}$ Guyon, Vie, 92.
} 
Through all these trials, Mme Guyon was transformed into a living saint. To prove this, she asserts that her motivation to do good deeds improved almost daily, and that she gained a reputation for extreme charity. Mme Guyon assumes a Franciscan tone when discussing her generosity, as she focuses all her efforts on the poor in her town. "In acts of charity I was very assiduous. So great was my tenderness for the poor, that I wished to have supplied all their wants.... I deprived myself of all I could to help them. ${ }^{256}$ Mme Guyon's own references to her works of charity are extensive, and seem to be the most obvious way that she links herself with accepted saints. As discussed in chapter three of this thesis, the action of immoderate charity was a characteristic of many Catholic saints, a trait which the Church encouraged and which she would have been very familiar with. The many references to behaving in such a giving manner, even when she was filled with sin, may be Mme Guyon's way to establishing that there was always this good, saintly quality within her because of God. "Few indeed could carry charity much farther than out Lord enabled me to do, according to my state, both while married and since. ${ }^{257}$ Much in the manner popular with prominent saints like St. Teresa of Avila, or Angela of Foligno, Mme Guyon describes how she visited and comforted the sick, dressed their wounds, and buried the dead. These kind acts allowed her to gain more gifts from God, and in late 1672 she was given the ability to make miraculous healing ointments for these same poor.

\footnotetext{
${ }^{256}$ Guyon, Vie, 138.

257 Guyon, Vie, 138.
} 
In fact, from this point forward Mme Guyon begins to assert that she had unearthly abilities transferred into her by God. The final years of her marriage to Jacques Guyon signify a period when she was united with the Lord, and was partner in a conjugal relationship with Him. Sometimes, Mme Guyon's soul was lifted supernaturally from her body in order to be with her heavenly spouse in private. At these times, her physical body would function by instinct alone. She writes, "it has seemed to me that my mind is so detached and absent from the body, that I do things as if I did them not. If I eat, or refresh myself, it is done with such an absence, or separation, as I wonder at, with an entire mortification of the keenness of sensation in all the natural functions." ${ }^{258}$ Mme Guyon was also given an inner sense for foretelling the future, which she did successfully in June of 1672 when her father died. According to her Vie, her new abilities told her that M. de Bouviers would die in a few days. ${ }^{259}$ The gifts from God, miracles as she calls them, continued to increase and in 1667 Mme Guyon was bestowed with the power to send the grace of God physically through her own body and into that of others. Speaking of an unnamed woman who came to her for spiritual advice, Mme Guyon writes that:

She had a great share of understanding, but was surprised at my expressing things to her so far above my natural capacity. I should have been surprised at it myself. It was God who gave me the gift for her sake, diffusing a flood of grace into her soul.... Since that time her soul has been a temple of the Holy Ghost. ${ }^{260}$

${ }^{258}$ Guyon, Vie, 139.

${ }^{259}$ See Guyon, Vie, 143-145 for details of this incident.

${ }^{260}$ Guyon, Vie, 150. 
This experience marks the beginning of the superabundance of God's grace which slowly overwhelmed her, but also shows that she was not surprised at the fact that this gift was conferred upon her. Indeed, the increasing abilities which Mme Guyon claimed to possess were not shocking to her, no doubt partially due to the fact that she expected them due to her chosen status. If other saints or holy persons were given similar abilities, than surely she, as bride of Christ, was also qualified to perform comparable deeds.

In no way are the astounding abilities of Mme Guyon more clear than after the death of Jacques Guyon in July 1676. Upon hearing that her husband expired, she went into her closet and exclaimed, "Oh my God,... thou hast broken my bonds, and I will offer thee a sacrifice of praise." ${ }^{261}$ The death of her husband, then, appears to set her free to worship as she pleases, and to give all her attention to her heavenly spouse. Of course, before this could truly happen Mme Guyon had to settle the estate of her deceased husband, and Jesus Christ helped her to do so in an expedient manner. She writes:

I was ignorant of business affairs; but God, independent of my natural understandings, always made me fit for everything that please Him, and supplied me with such a perfect intelligence that I succeeded. I omitted not the least minutia, and was surprised that in these matters I should know without ever having learned. ${ }^{262}$

Following in this sentiment, she claims that God allowed her to understand legal terminology and the like by acting through her. Indeed, Mme Guyon says that upon settling these matters that she could not discuss them because she could

\footnotetext{
${ }^{261}$ Guyon, Vie, 164.

${ }^{262}$ Guyon, Vie, 165.
} 
not remember them: God had acted through her without her knowledge of it. She exclaims, "for after they were settled I knew nothing about them; and if I now hear any talk of such things, to me it sounds like Arabic." ${ }^{263}$ Having been freed from financial responsibilities, Mme Guyon waited to hear the call of the Lord telling her what to do next. Indeed, a miracle occurred when she received a letter from Father La Combe, a Barnabite priest whom she had met a few years earlier through her brother. After the death of Jacques Guyon, Mme Guyon felt that God wanted her to convert Father La Combe to the inner prayer. She contemplated this for a year or so, during which her ability to perform miracles increased. She writes regarding her activities in 1677 that, "I resumed my care of the sick [which had been postponed due to legal matters], and dressing of wounds, and God gave me to cure the most desperate. When surgeons could do no more, it was then that God made me cure them." ${ }^{264}$ Mme Guyon also received the gift of prophecy more clearly at this time, and her Vie has a detailed discussion on how to tell if a dream was a true divine vision. In summation, Mme Guyon knew that she was receiving "mysterious dreams" from God because they left a certainty that they were mysterious and would be proven true in time, they were hardly ever effaced from memory, they became more convincing each time one thought of them, and they left a "divine sense." 265 The presence of heavenly-inspired dreams begins to pervade the text from this

\footnotetext{
${ }^{263}$ Guyon, Vie, 166.

264 Guyon, Vie, 193-194.

${ }^{265}$ Guyon, Vie, 202.
} 
moment on, as Mme Guyon continued to assert that she was a chosen one of God.

Having been given the gift of prophecy, Mme Guyon felt convinced that she was supposed to leave her family and friends behind in order to go and join the New Catholics in Geneva. It is unclear how or why she believed this place was her destiny. As Geneva was the stronghold of Calvinism, it seems likely that she believed her ability to convert persons to the inner way could be exceptionally convincing. It is clear that she viewed this calling as the destination God had prepared for her since an early age. Mme Guyon writes, "The laws of my sacred marriage obliged me to give up all, to follow my spouse whithersoever it was His pleasure to call me after Him. Though I often hesitated, and doubted much before I went, I never doubted after my going of its being His will." 266 To prepare her for the journey, God conferred upon her one more divine gift: the ability to discern the state of spirits. ${ }^{267}$ Such a favor ensured that she was meant to teach the doctrine of the inner way, as she could now discern the spiritual status and progression of those who would become her followers. The analogy to the woman of the apocalypse in relation to the Vie now gains significance, as Mme Guyon was assured by the time she left France for Geneva in 1680 that she was the living saint and mature bride of Christ who was meant to spread inner prayer, the child of Jesus placed in her, over the earth.

\footnotetext{
266 Guyon, Vie, 209.

267 See Guyon, Vie, 206-207 for a discussion of this state.
} 
Describing the period of her time away from Paris, from 1680 to July 1686, Mme Guyon appears most adamant about constructing herself as a saint. Indeed, the death of her husband in 1676 appears a watershed for her mystical, inspired activities, as it was after that point that she obviously felt that she was the chosen bride of Christ. After all, as we have heard, the death of $M$. Guyon was a welcomed event, one which now allowed her to behave as the living bride of Christ without having an earthly spouse to dominate her attentions.

She begins the retelling of her new widow's life with a detailed description of her journey to Geneva. Prior to leaving France, Mme Guyon made the decision to leave her two sons in the care of her mother-in-law, feeling that they would only be a burden to her calling. However, she refused to leave her daughter, five-year-old Jeanne-Marie Guyon, behind with family, and took the child and two maids with her. These traveling companions are interesting. Mme Guyon insisted on bringing her sickly daughter with her, for reasons which may center around her insistence that the little girl was a tool through which God verbally spoke to her. During their journey to Geneva, Jeanne-Marie Guyon was inhabited by a divine spirit, and made crosses over her mother. Mme Guyon writes:

She then put around, and all over me, above three hundred of them [the sign of the cross]. I let her do it, and inwardly apprehended that it was not without meaning. I felt an interior certainty that I was going to meet with crosses in abundance and that this child was sowing the cross for me to reap it. Sister Garnier [another traveling companion], who saw that they could not restrain her from covering me with crosses, said to me, "what that child does appears to be significant." Turning to the little girl, 
she said, "Give me some crosses, too, my pretty pet." "No," she replied, "they are all for my dear mother." 268

Mme Guyon was given signs by the Lord through her daughter, who both signaled her holiness by making the sign of the cross over her and, as is indicated, foretold many (more than three hundred) crosses that were to come. During this same journey, the little girl also made a disturbing proclamation, as she gathered some flowers and placed them on her mother's head saying, "After the cross you shall be crowned." ${ }^{269}$ This seems to deliberately indicate that Mme Guyon is crowned, like the woman in the apocalypse, for her silent, humble bearing of persecution. According to the interpretation of Mme Guyon's life as fulfilling chapter twelve of the Book of Revelation, she suggests (in hindsight, through the writing of her autobiography) that she would soon be in travail to deliver the child, or the doctrine of the inner way, of Christ.

Despite Mme Guyon's claim that she embraced extreme poverty (Franciscan style, we are led to believe) by giving all her money away to family, she took these two maids along with her to serve her and her daughter; thus, Mme Guyon financially supported four persons. This is the beginning of a highly complicated, and confusing, documentation of her financial status. She writes that she had given up all: "I reserved not to myself a single penny, rejoicing to be poor after the example of Christ." ${ }^{270}$ Mme Guyon describes herself as so poor, and so charitable, that she even gives away the "little plain ring" that had

\footnotetext{
Guyon, Vie, 220.

Guyon, Vie, 220.

270 Guyon, Vie, 221.
} 
signified her marriage to Jesus Christ. ${ }^{271}$ Yet, as the text unfolds, Mme Guyon refers now and again to the fact that she had a considerable amount of her husband's estate left which she refused to part with. After being asked to leave Geneva because of the attention she got there, Mme Guyon took up residence with the New Catholics in Gex, a small town about fifteen miles north of the Calvinist stronghold. She writes about her finances at this time, saying, "though what I had reserved to myself was sufficient to support me in this place; yet it was scarcely enough to do so in some other places." ${ }^{272}$ This implies that she was receiving some kind of annuity, or had money on hand. Such an assertion is intermixed with statements to the contrary. For example, Mme Guyon confirms that "my persecutors did not fail to report that I had brought great sums from home... false as I had not a penny." ${ }^{273}$ This is an obvious contradiction which I believe to be an outstanding indicator that the autobiography was an attempt on Mme Guyon's part to construct her life as that of a living saint. Poverty was required for pious persons, and yet she could not in reality bring herself to such a level. Such a discrepancy had to be accounted for. It appears that she endeavored to do so by overstating her acts of charity, and by scrambling the references to her finances to make them difficult, if not impossible, to follow. This assertion can be further supported because by saying she was penniless, she may be referring to the fact that she had no coin money on her person. The wealth of her estate, which was considerable, seems to have been ignored as 
constituting wealth because she did not have immediate access to it. In order to have drawn on the income of her estates, she would have needed to draw up letters of credit. Technically, then, Mme Guyon could be correct in saying she had no money with her -- but she still had money available to her. The Vie does not speak directly of this distinction, as she had to speak of poverty in order to confirm her sanctity. Mme Guyon did not necessarily lie about her financial status, she just mixed the facts of her financial conditions to her benefit.

The intentional effort of Mme Guyon to disguise the fact that she could not accept total poverty, and thus did not conform to accepted saintly behavior, can be further seen in small passages regarding her maids. I want to emphasize here that at all times past 1680 she had at least one maid, certainly not a practice which those desiring to live like Jesus in total poverty could afford (or even want). The words of Mme Guyon speak for themselves in this following passage, referring to her stay with the New Catholics of Gex in 1682:

I had two maids to serve me; yet, as the community had need of one of them for their cook, and the other to attend the door and other occasions, I gave them up, not thinking but that they would allow them to serve me sometimes. Besides this, I let them still receive all my income, they having had my first half of this year's annuity. Yet they [the New Catholic superiors] would not permit either of my maid-servants, to do anything for me." 274

One might wonder what exactly Mme Guyon, the living saint who was constantly filled with the spirit of the Lord and who was living "poverty," might need servants for. She soon tells us:

\footnotetext{
273 Guyon, Vie, 222.

274 Guyon, Vie, 247.
} 
By the office of sacristan I was obliged to sweep the church, which was large, and they would not let anyone help me. I have several times fainted over the broom and have been forced to rest in corners.... What most embarrassed me was that I never had washed. I was now obliged to wash all the vestry linen. I took one of my maids to help me, because in attempting it I had done up the linen most awkwardly. These sisters pulled her by the arms out of my chamber, telling her she should do her own work. I let it pass quietly, without making any objection." 275

While these two examples might appear to be the innocent, and necessary, de-noblization of Mme Guyon in accordance with her own wishes to live in a religious community, they become the basis for the crosses she is to bear. Indeed, her servants are viewed as being against her for not helping with these chores (sweeping and laundry). The other sisters who encouraged the maids to do other things are also viewed as condemning her, and the end result of having to do manual labor for herself was that Mme Guyon viewed the house of the New Catholics as a place of persecution, much like that of the Guyon home after her marriage.

During her stay in Gex, which lasted from late 1680 to early 1683, Mme Guyon converted Father La Combe to the inner way. However, he refused to follow her directions precisely, and his constant questioning of her method and her union with God proved highly frustrating. This section of the autobiography regarding Gex leads the reader to the conclusion that Mme Guyon considered herself a spiritual reincarnation of St. François de Sales, who had lived in nearby Annecy while serving as the bishop of Geneva. This may seem an outrageous

${ }^{275}$ Guyon, Vie, 247. 
presumption, but her text will show this to be the case. Mme Guyon writes

during a visit to St. de Sales tomb that:

There also I felt a sweet remembrance of that saint, with whom our Lord gives me singular union. I say union, for it appears to me that the soul of God is united with saints, the more so in proportion as they are conformable to Him. It is a union which it please God sometimes to revive after death, and awaken in the soul for His own glory. At such times departed saints are rendered more intimately present to that soul in God; and this revival is as it were an holy intercourse of friend with friend, in Him who unites them all in one immortal tie. ${ }^{276}$

Because she was constantly united with God, as were the deceased saints, Mme Guyon asserts that she was able to unite with them as well in a supernatural friendship. In this manner, Mme Guyon considered herself to be joined in spirit with St. de Sales and to be able to communicate with him spiritually through the medium of God. In this scenario Father La Combe becomes St. Jeanne de Chantal, and indeed this intention is exposed. Mme Guyon displays an intimate desire to make La Combe her most influential convert, and encourages him to write detailed letters with her, to write manuals of the inner way (his An Analysis of Inner Prayer was published in 1683), and to found hospitals together.

Ultimately, Mme Guyon seems to have wanted to found a religious community with the help of La Combe where persons could learn and practice inner prayer. All of these projects are described in the Vie, in a method which seems to be analogous to the association of St. de Sales and St. Chantal.

The relationship between Mme Guyon and Father La Combe is highlighted throughout the autobiography's description of the years when she

${ }^{276}$ Guyon, Vie, 223. 
was living outside of France. Their close companionship resulted in God's allowing them to communicate silently. Mme Guyon describes this intimate association between herself and La Combe as "divine." "I gradually perceived, when Father La Combe entered, that I could speak no more. There was formed in my soul the same kind of silence towards him, as was formed in it in regard to God." 277 This silent language which was shared between them was the "language of angels," and allowed the two to understand each other in God, "after a manner unutterable and divine. ${ }^{278}$ God simultaneously entered Mme Guyon and La Combe in such a matter that was "so pure and so sweet" that they passed hours "in this profound silence, always communicative, without being able to utter one word." 279 La Combe even saves her from death by begging God to allow her to live. Mme Guyon writes that he was:

on his knees at my bedside, remarking the change of my countenance, and how my eyes had faded, seemed ready to give up, when God inspired him to lift up his hands, and with a strong voice, which was heard by all who were in my room, at that time almost full, to command death to relinquish its hold. Instantly it seemed to be stopped. Thus God was pleased wonderfully to raise me up again.... ${ }^{280}$

The relationship between Mme Guyon and Father La Combe, if we are to believe her words, was divine, the two souls moving and speaking together being directed by the will of God alone. In this scenario, however, Mme Guyon failed to consider that La Combe, by her own standards, was not on the same spiritual level as herself. Indeed, it appears from her experiences with him that

\footnotetext{
277 Guyon, Vie, 286.

278 Guyon, Vie, 286.

279 Guyon, Vie, 287.
} 
La Combe was able to achieve union with God through her, but by himself he could not because he had not gone through all the steps to union. She confirms this by quoting a passage from a letter La Combe wrote to her: "When I stand well with God, I find I am well with you. When I am otherwise with Him, I then find myself to be so with you also." 281 Mme Guyon confirms this sentiment, and implies that it is only through her that others can attain union with God. She states, "Thus he [La Combe] clearly saw that when God received him, it was always in uniting him to me, as if He would accept of nothing from him but in this union." ${ }^{282}$ Mme Guyon was the only means to unite with God. In this circumstance, she is the supreme authority, and despite La Combe's progress, he is unable to reach the final stages without her assistance.

A great component of inner prayer, as sought by La Combe and others, was persecution, a factor which cannot be overemphasized. However, in order for La Combe to be fully converted to the inner way, and to allow his self-love to be annihilated in order that God should unite with him, Mme Guyon felt it necessary that he withstand terrible persecutions. In 1682 or so when the two came under great criticism, headed by the bishop of Geneva, for having sexual relations, Mme Guyon writes of the period that, "at first I was too ready to vindicate him, thinking it justice to do it. I did not do it at all for myself; and our Lord showed me that I must cease doing it for him, in order to leave him to be

${ }^{280}$ Guyon, Vie, 289.

281 Guyon, Vie, 300.

282 Guyon, Vie, 300. 
more thoroughly annihilated." 283 The result of this persecution was that La Combe was summoned to Rome to explain his actions. During his absence, Mme Guyon decided that she should live in Thonon, the town near Gex where La Combe served as priest, and she moved into the house of the Ursulines in 1683. It was there that the woman of the apocalypse, anxiously bearing the criticism of her family, the New Catholics, the bishop of Geneva, and others against her, gave birth to the child who would rule the world with an iron rod. I am of course speaking of the doctrine of the inner way, which found immortality through the composition of Moyen court et très facile pour l'oraison que tous peuvent pratiquer très aisément (The Short and Easy Method of Prayer) in late 1683. Almost symbolically the dragon, Satan himself, visited her shortly before she penned this book in elaborate circumstances. One night while she was sleeping, "something very monstrous and frightening presented itself." ${ }^{284}$ She continues:

It seemed a kind face, which was seen by a glimmering bluish light. I don't know whether the flame itself composed that horrible face or appearance; for it was so mixed and passed by so rapidly, that I could not discern it.... I heard frightful noises in my chamber and after I had lain down they were still worse. My bed often shook for a quarter of an hour at a time, and the sashes were all burst.... I made use of my little light to look all over the room and at the sashes, at the very time the noise was strongest. As he [the devil] saw that I was afraid of nothing, he left off all on a sudden, and attacked me no more in person." 285

This vision is strikingly similar to descriptions in the lives of saints, and especially those of some popular medieval female virgin martyrs. Two come

${ }^{283}$ Guyon, Vie, 267

${ }^{284}$ Guyon, Vie, 243-244. 
readily to mind: St. Juliana (from The Song of Roland fame), patron of difficult childbirth, defeated the devil when he appeared to her at night in a dark cell; St. Margaret of Antioch also defeats the devil when he appears in the form of a dragon by stabbing him with a cross. ${ }^{286}$ Like them, Mme Guyon defeated Satan when he attacked her at night in her small room. The persecution which resulted from this defeat, stirred up continually by spiteful Satan, resulted in the growing criticism of Mme Guyon at Thonon. As the rest of this chapter will show, this same devil was to follow her throughout her journeys, possessing persons who would, in turn, persecute her. Once again, this vision harkens back to the Book of Revelation, when the dragon pursued the woman of the apocalypse. Mme Guyon stayed at the home of the Ursulines, despite the hardships she had there, for two years, during which time there was an outstanding explosion of saintly qualities in her.

The aspects of sanctity that have already been mentioned, including the ability to heal the sick, the capability to control natural phenomena, and the gift of discernment of the spiritual state of others, were further advanced at Thonon. With the writing of Moyen court, Mme Guyon also seems to have considered her new role to be that of charismatic, and aggressive, teacher. The birth of her child, as inspired by God, now necessitated that she convert people on a wide

\footnotetext{
${ }^{285}$ Guyon, Vie, 244.

286 The legend of St. Margaret of Antioch is intriguing, as Mme Guyon describes that Satan (the dragon of self-love) can be defeated by withstanding the cross - the death of the self. Likewise, the fact the St. Juliana is the Catholic patron of difficult childbirth brings to mind the travailing woman of the apocalypse. Since Mme Guyon's experience is a singular phenomenon in the autobiography, it may be possible that she was symbolically mimicking these two popular saints; this conclusion, however, is
} 
scale in order to fulfill the Revelation prophecy that the children of the woman of the apocalypse would someday rule the earth. She writes that, "also I perceived the quality of a spiritual mother; for the Lord gave me what I cannot express for the perfection of souls." ${ }^{287}$ In accordance with this, the autobiography teems with countless examples of persons who flock to her because of her outward countenance of holiness. Mme Guyon was still primarily concerned with the spiritual status of Father La Combe, who seemed to be struggling with his journey to union with God, but this did not stop others from seeking her out. Several Catholic monks, priests, and nuns visited her and were converted to the inner way: to them she gave copied manuscripts of Moyen court. The book was thus distributed and passed among religious persons, and gained so much attention that it was published in Grenoble in mid-1684. This publicity brought further attention to her activities in Thonon, and some noble women there were overcome with her spiritual gifts, and offered to contribute a considerable sum for the building of a hospital. This was the first successful joint project of Mme Guyon and La Combe, and she took the founding of this institution as a sign that God had chosen them to be eternal companions. In 1684, Mme Guyon's reputation for holiness motivated the Marchioness of Prunai, sister of the chief Secretary of State to the Duke of Savoy, to invite Mme Guyon to live on her large Italian estate. Although initially turning this invitation down, Mme Guyon quickly changed her mind when she was told by La Combe 
that he had been assigned as confessor to the bishop of Vercelli, a town relatively close to the marchioness's home in Turin.

The period of Mme Guyon's life at Turin represents a tremendous growth in her abilities of prophecy. Upon arriving at the marchioness's house, Mme Guyon found that her hostess was not as receptive to inner prayer as she had hoped, and the two quickly became disenchanted with each other. She writes of this period that, "the marchioness of Prunai, who had been so warmly desirous of my company, seeing my great crosses and reproaches, looked coldly upon me. ${ }^{\prime 288}$ To counteract this, Mme Guyon began foretelling the future of the marchioness and her family in order to confirm her chosen status. She says, "Our Lord, however, made me foretell events which should happen, which since that time have actually been fulfilled, as well to herself and her daughter, and to the virtuous ecclesiastic who lived at her house." ${ }^{289}$ Eventually, through several misfortunes which struck the marchioness, including the death of her husband, "she did not fail, at last, to conceive more friendship for me, seeing that Christ was in me. ${ }^{290}$ The situation at Turin, despite the kind feelings which were stirred in the marchioness, continued to deteriorate, and Mme Guyon left for Grenoble in early 1685.

Before her departure for France, Father La Combe decided that he wanted nothing more to do with her because of her prophecies regarding the

\footnotetext{
${ }^{287}$ Guyon, Vie, 279.

${ }^{288}$ Guyon, Vie, 297.

${ }^{289}$ Guyon, Vie, 297-298.

${ }^{290}$ Guyon, Vie, 298.
} 
marchioness. Mme Guyon says, "he was angry with me, and prejudiced against my state." 291 La Combe was distrustful of her gift of grace, and began to doubt her teachings claiming that she was "full of pride." ${ }^{292}$ However, as the marchioness was taught not to doubt Mme Guyon, so La Combe was soon shown by God (we are told in the autobiography) that he was wrong to doubt her. Mme Guyon writes that, "some time after he was more enlightened in regard to the state I was in. He then said, 'continue to believe as you have done; I encourage and exhort you to do it. ${ }^{\prime \prime 293}$ Despite this reported reconciliation, the Vie tells sadly that La Combe would not follow her to Grenoble because of the sexual insinuations that would result. She accepted this, and left without him.

Upon arriving in Grenoble, Mme Guyon was treated like a celebrity. Individuals went to great lengths to see her, and she writes that, "it came to such excess, that, generally from six in the morning till eight in the evening, I was taken up in speaking of the Lord. People flocked on all sides, far and near, friars, priests, men of the world, maids, wives, widows, all came one after another." 294 Some of the persons who had received her advice thought that she was entirely misled, and did not hesitate to say so. However, Mme Guyon seems to take this in stride, likening herself to Jesus by saying, "Our Lord, among such multitudes as followed Him on earth, had few true children." 295 As her reputation spread, persecution erupted when persons would visit her only to find her in a state of

291 Guyon, Vie, 299.

292 Guyon, Vie, 301.

${ }^{293}$ Guyon, Vie, 301.

${ }^{294}$ Guyon, Vie, 306. 
silence, and soon many of the ecclesiastics and citizens were enraged against her. To Mme Guyon, these crosses further emphasized her chosen status, and she states, "it is certain that all the souls employed herein by apostolic destination from God, and who are truly in the apostolic state, are to suffer extremely. ${ }^{296}$ During the months she was in Grenoble, Mme Guyon was divinely inspired to write her controversial Bible commentaries, including chapters on Genesis, Job, Exodus, and the Song of Songs (the commentary on the Book of Revelation was written later). These were circulated in manuscript form to all of her new 'children,' who encouraged her to publish them formally. The devil, the dragon of the apocalypse who had fallen from heaven and was stirring up persecution against the woman, became more enraged and encouraged people to condemn her writings. Mme Guyon's response to this was, "let him stir up against me ever so strange persecutions. I know that they will all serve to the glory of my God." ${ }^{297}$

Despite this brave visage, in the dead of winter 1685, Mme Guyon conceived the idea that she must return to Vercelli to speak with Father La Combe. What resulted was a miserable journey into Italy in which she was condemned by the Italians for every reason imaginable. She did not speak Italian well; she was French; she and her maids were traveling without a chaperone. Sparing the relation of the details of this disastrous expedition, she arrived in Vercelli in early 1686. La Combe was furious, and said that he did not want to 
see her again. He told her that, "everyone would think I was come after him, and that would injure his reputation, which in that country was very high." 298 What follows in the autobiography is a painful recollection by Mme Guyon of the obvious failure in the vision of herself and La Combe being spiritually bound. Of course, her rejection by La Combe is hardly bewailed, as it becomes instead one more example of her divine nature. Although she only remained in Vercelli for a few months, the true spirit of Guyonism found expression as Mme Guyon penned her commentary on the Book of Revelation during her stay there.

While Mme Guyon was in Vercelli, Miguel de Molinos was arrested in Rome by the Inquisition, and was imprisoned for life. As presented in chapter two, Mme Guyon claimed to have had no knowledge of this incident, or of this individual, until after her arrival in Paris in July 1686 . However, considering she was often sharing in conversation with the bishop of Vercelli, as well as with Father La Combe and other priests, it is unlikely that her assertion about Molinos is true. This is another piece of evidence that Mme Guyon had specific goals in mind when she wrote her Vie. Aware during her imprisonment in 1688 that she was being labeled as a follower of Molinos, she had to compensate for this by reconstructing her own life to show that this association was impossible. After all, any association with his doctrine would take away from the saintliness of her own; Mme Guyon was in her mind, after all, the woman of the apocalypse. This evidence also supports her own assertion that she had already formed her own

297 Guyon, Vie, 325.

298 Guyon, Vie, 343. 
doctrine of inner prayer by the time she heard of Molinos: Mme Guyon wrote Moyen court in 1684 in Thonon, before she went into Italy. Therefore, a connection with Molinos is unlikely. At the time of her first imprisonment for heresy, the charges that Mme Guyon was another Molinosist were dropped, and after she was released in 1689 the Church authorities seemed to have abandoned this association. It was not until Bossuet and the Council of Issy in 1694 that the correlation was reexamined, at least superficially (see chapter 2).

In Paris in 1684, the Father-general of the Barnabites died, and Mme Guyon's brother who had scorned her ever since her flight from France, Father de La Mothe, filled the position. Desiring to lure his sister back into France, de La Mothe appointed Father La Combe as his assistant, hoping the Mme Guyon would follow. Indeed in mid-1686, this was exactly what happened. By this time, Mme Guyon reports that she had founded as many as four hospitals - in Thonon, Grenoble, Marseilles (during her two weeks there in 1685) and Vercelli - all of which subsisted "without any other fund than the supplies of Providence. ${ }^{299}$ Upon her arrival in Paris with Father La Combe as her traveling companion, persons began to slander both of them out of jealousy for their inner prayer, maintains Mme Guyon in her Vie. Father de La Mothe, aware of the arrest of Molinos in Italy, began a campaign saying that La Combe was a follower of the Spiritual Cuide. By October, Father La Combe was arrested and placed in prison, where he lived until his death in 1715. According to Mme Guyon, she never spoke or wrote to him again. In order to justify this, the final 
pages of the Vie which were written during her own imprisonment in 1688 relate that she did not make any solicitation for him because it was her hope that this great cross would lead him closer to union with God. As for her own condition, Mme Guyon wrote that, "The more persecution raged against me the more children were given to me, on whom the Lord conferred great favors through His handmaid." ${ }^{300}$ When she was arrested in January 1688 on charges of "infamy, error, sorcery or sacrilege," Mme Guyon rejoiced as this cross was inflicted on her by divine will; she was, however, most distraught because her daughter and maid were not going to be allowed to serve her in prison. ${ }^{301}$ After all of the crosses she had endured in the past eight years, the lack of a good servant seems to have been the most intolerable.

It is here that the discussion of Mme Guyon's autobiography as a hagiography comes to a close. The remainder of the volume, which describes with incredible brevity her association with Fénelon, the Council of Issy, and her imprisonment in the Bastille, were all written during the period from 1699 or so to 1709 . The analysis presented above is meant to present Mme Guyon as a living saint, who wrote her own life's story in order to vindicate not only her actions, but her chosen position as bride of Christ. The very fact that she wrote an autobiography is significant, as it shows that she thought her own life story, and the role she was to play in the future as the mother of Christ's true prayer, 
important enough to document. The Vie can be seen as a defensive maneuver, cleverly constructed not only to vanquish her immediate critics, but also to serve as a guide for her children who would someday desire to read about their spiritual mother. Along the way, I have presented several points of deviation from accepted saintly piety within this text - her refusal of the pious, povertyoriented lifestyle, the constant justification for the slander against her, and the subtle complaining about the offenses against her - as focal points to highlight the intentions underlying the Vie. This chapter has shown Mme Guyon doing many of the activities of accepted Catholic saints. She gained power and influence, albeit sometimes negatively, by teaching her doctrine. Mme Guyon also acted immoderately by performing miracles and by speaking often and to anyone about her inner prayer. Most of all, however, Mme Guyon has been shown as suffering horribly, as exemplified through an excessive sense of persecution, illness, and personal struggles with sin. By writing her autobiography Mme Guyon seems to be mimicking the requirements of sanctity by accentuating them, or creating them, in order to minimize any deviations from her own doctrine of Pure Love.

Finally, the goal of this chapter has been to show that Mme Guyon's Vie cannot be taken at face value. It seems likely that some or many of the incidents described in the text were purposeful stories meant to convey her sanctity and chosen status. It is not my intention to claim that this entire text is a hoax, or generally a spurious story with little historical merit. Nonetheless, Mme Guyon's

${ }^{301}$ Guyon, Vie, 362-363. 
work must be placed in context by those reading it. This was not an innocent writing, penned for her grand children or great grand children for personal immortality. The Vie is three volumes of directed writing meant to provoke the reader to the conclusion that she was a living saint, a goal which, as demonstrated, propels the text in explicit directions. 


\title{
Conclusion: \\ Mme Guyon and The Legacy of her Self-Constructed Sanctity
}

\author{
Eye has not seen, ear has not heard, \\ nor has it so much as dawned on man \\ what God has prepared for those who love him. \\ 1 Corinthians 2:9 (quoting Isaiah) \\ $\mathrm{O}$, my God, if thou art pleased to render me a \\ new spectacle to men and angels, \\ Thy holy will be done! \\ leanne Cuyon
}

This thesis has discussed the self-proclaimed sanctity of Mme Guyon, a woman who lived and wrote as though she were the unquestioned, and highest, bride of Christ. After focusing on the Quietist controversy of the late seventeenth century, in which Mme Guyon was accused of thinking herself a living saint by Bossuet, I attempted to show through study of her writings that this allegation was, indeed, true. Mme Guyon went to great lengths to create and recreate herself as the highest saint of all: the woman of the apocalypse who also has the honor of being the one real identifiable wife of Christ. This belief is supported by her writings, especially the Vie which, as I have presented, appears to be a autobiographical hagiography created to give authority to her claims and to her teachings.

In order to make sense of Mme Guyon's interpretation of herself, I have endeavored to unite several aspects of her teachings and personality as seen through her purposeful writings. These factors include the imagery of the Book 
of Revelation, sainthood, mysticism, sensuality in reference to Jesus, and persecution. Just one, or even two of these categories, when examined individually, would lead to a fractured interpretation of Mme Guyon. When examined together as necessary parts of the whole of her personality, however, these factors support my assertion that she considered herself the woman of the apocalypse. Each of these traits - the endless persecution, the Revelation imagery, the assertions of sainthood and being co-heir with Jesus, the discrediting of non-Guyon mysticism, the sexual references - are intertwined in the writings of Mme Guyon in a way which alerts the reader of her chosen status.

In the beginning of this journey to sanctity, the key question to be addressed by this thesis dealt with the exact nature of Mme Guyon: was she a saint or heretic? It is clear now that she was both, and knowingly so. Mme Guyon clearly understood that she was a saint, and was the mother of the doctrine of inner prayer that would welcome in New Jerusalem as the rest of the world fell into eternal hell. To her followers then and now, she is a saint as well, a woman who had a miraculous gift of being truly touched by God.

Contemporary Evangelical Christians embrace Mme Guyon as a central figure in their quest for the inner life, and its satisfying sanctification. Some, like Dorothy Gawne Costlet, have painted her as a female Martin Luther, and as the 
founder of a new "reformation" of sorts based on spiritual union with God. ${ }^{302}$ Mme Guyon also seems to have set the tone for the interpretation of the woman of the apocalypse as a real, living woman. For example, founder of Christian Science, Mary Baker Eddy, assumes a Guyonist tone in her own commentary of the Book of Revelation, thus supporting the successful nature of Mme Guyon's vision of herself as a real spouse of Christ bearing his children. ${ }^{303}$ While she may not have been formally canonized by the Catholic Church, Mme Guyon certainly has achieved immorality in some circles for her forthright sanctity. Yet, Mme Guyon was aware that her doctrine was not persecuted without reason. It seems from the evidence presented throughout this thesis that Mme Guyon knew she was making some statements that could be interpreted as heretical. After the decision of the Council of Issy in March 1695, Mme Guyon fully accepted that she had erred in some points of her doctrine, and signed a paper acknowledging these inaccuracies. Within a few months, as Bossuet complains incessantly in his Relation sur le Quiétisme, she made the conscious decision to renege on her word, and resumed teaching her doctrine. Mme Guyon acknowledged that she was preaching heretical sermons by signing the Articles of Issy. Yet she continued, and even seemed to accelerate her efforts within only a few months of submitting. The only possible answer to why she

302 Dorothy G. Costlet, Madame Jeanne Guyon: Child of Another World (Fort Washington, PA: Christian Literature Crusade, 1995). See chapter 9 for her specific argument that Mme Guyon is a spiritual reincarnation of Martin Luther.

${ }_{303}$ Mary Baker Eddy, The Revelation of St. John: An Open Book (Dorchester, MA: The Open Book, 1922). It is unclear whether Ms. Eddy had read Mme Guyon and was purposefully copying her tone; the evidence, however, seems overwhelmingly in favor of this. 
would place herself in the line of fire is that to do so would help fulfill her own prophecy. As discussed in chapter four and five, persecution was a crucial part of her doctrine, and worldview. Without constant condemnation, preferably from influential Church officials, Mme Guyon's entire theology would fail, and she would no longer be able to associate herself with the woman of the apocalypse. This is because the woman in the Book of Revelation was pursued constantly by the dragon, or Satan, who poured out a river of slander against her. Mme Guyon's own vision of herself and her role in the world required that she defy the Church; she needed the persecution to justify her own existence. Is Mme Guyon an unknowing heretic, as so many historians have sought to claim? Certainly, in terms of the Church and theological ideas of sanctification, Mme Guyon violated some religious doctrines, especially regarding prayer. Moreover, and this is the overlying theme of this thesis, she was a self-made heretic. When the occasion required that she defy Catholic teachings in order to make a point of her self-sanctity, Mme Guyon would do so, either in reality or by creating the opportunity for punishment in her writings. When the circumstances required that she bend the rules in order to bring on more persecution, which in turn would support her claim as the woman of the apocalypse, Mme Guyon pushed ahead with her teachings by defying Bossuet and other Church authorities. I have suggested that her steadfast conviction of being the highest bride of Christ was the foremost goal of all her actions, writings, and conversations, and the 
preservation of this ideology meant that any action, even unintentional or intentional heresy, was acceptable.

Was Mme Guyon really as ignorant as people thought? Obviously, from the evidence presented in this thesis, Mme Guyon's reputation for being crazy, possessed, and unintelligent deserves reevaluation. When Voltaire described her in this manner in The Age of Louis XIV and her contemporary the duc de Saint Simon commented in his memoirs on her lack of mental capabilities, they must have been responding to the overarching philosophy of the period which viewed Mme Guyon as a dangerous, destructive force. This sentiment, however, by no means disappeared with the closing of the eighteenth century. Pierre Goubert, writing in the 1970's, characterized Mme Guyon as "a somewhat hysterical visionary. ${ }^{\prime \prime 04}$ Mme Guyon has gained celebrity in the nineteenth and twentieth centuries, especially in Catholic and academic circles, as having seriously impeded the careers of Fénelon and Bossuet. Even recent histories, like The Reign of Louis XIV edited by Paul Sonnino, portray Mme Guyon as being instigator and sustainer of this great ecclesiastical battle. ${ }^{305}$ Mme Guyon has not always been depicted in light of Fénelon and Bossuet, and a few historians have sought to give her the credit she deserves by classifying her as "intelligent," but

\footnotetext{
${ }^{304}$ Pierre Goubert, Louis XIV and Twenty Million Frenchmen, Trans. Anne Carter (New York: Vintage Books, 1970), 274-275.

${ }^{305}$ See the essay "Intellectual History of the Reign" by Paul Sonnino, and "Religious History of the Reign" by John H. Grever in Paul Sonnino, ed. The Reign of Louis XIV (New Jersey: Humanities Press International, Inc., 1990), 170-171.
} 
"obstinate" and with an "ill-regulated mind." 306 This thesis has sought to prove the opposite. While there may be some evidence that Mme Guyon was subject to religious hysteria in some form, it is clearly unfair to classify her as unregulated and dull-witted. She recreated herself as a saint, carefully monitored her behavior and words, conscientiously portrayed herself as such in the large corpus of her writings. This behavior is not indicative of a woman who was mentally slow. Mme Guyon had also grown up in a noble household, was educated at length in religion if not in many other subjects, and had access to a wide array of books both before, during, and presumably after her marriage; it is difficult to classify such a learned individual as ignorant in any situation.

Some historians have argued that demeaning treatment of Mme Guyon is indicative of the misogynistic attitudes of her contemporaries which have been subsequently adopted by scholars. As I asked in the first chapter, was Mme Guyon persecuted only because she was a woman battling the authority of the Church hierarchy? Were Bossuet and his sexist ecclesiastical colleagues on personal missions to put this woman back in her rightful place? Marie Louise Gondal, author of Un nouveau visage, embraces such a vision wholeheartedly. She claims through the extensive analysis of primary sources that the three main adversaries of Mme Guyon - Bossuet, Jansenist Pierre Nicole, and pope Innocent XII - sometime after the Council of issy decided that Mme Guyon was

\footnotetext{
306 W.H. Lewis, The Splendid Century: Life in the France of Louis XIV (Garden City, NY: Doubleday Anchor Books, 1957), 87.
} 
challenging the accepted position of women within the Catholic hierarchy. She writes:

In summation, before the declaration of war, each of these three adversaries believed that they recognized in Mme Guyon something that rivaled the feminine. As a princess, she would have attracted their flatteries. As a nun, she would have presented no danger. As a saint, she would have served their authority. But as a woman in the secular state, she escaped their control. It was necessary to prevent this voice from being heard. It was necessary to destroy a 'venom which wins over the heart without the heart knowing it.' The various reactions of those involved in the battle show the depth of her impact. ${ }^{307}$

For Gondal, then, Mme Guyon became, almost without warning, a "feminine menace" that the great religious authorities had to deal with.

Having considered the evidence, I disagree with Gondal's conclusion. Her theory has many inconsistencies which are apparent by the evidence presented in this thesis, because in many ways this thesis has sought to address Bossuet's character as much as the woman he condemned. For example, why did Bossuet, Nicole, and Innocent XII, wait until after the Articles of Issy to "declare war?" Had they not seen enough already to convince them she was a menace after dealing directly with Mme Guyon for almost two years? Gondal answers this question by pointing out that shortly before "war" in early 1696 , Mme Guyon had reneged on her pledge to stop preaching her doctrine of the inner way. This action resulted in the panic of Church authorities, who only then realized that her behavior directly threatened their control. This is a convincing argument which seems to be upheld by the sources to a large extent.

307 Marie Louise Gondal, Un nouveau visage (Paris: Éditiones Beauchesne, 1989), 74. 
Nevertheless, as this thesis has pointed out, another important factor deserves consideration in this matter, namely Mme Guyon's self-canonization.

Gondal suggests that Mme Guyon was not a saint, and therefore would not have served the authority of the ecclesiastics; she was, in Gondal's words, in a "secular state." The evidence presented here concludes quite the opposite. Mme Guyon did consider herself a saint of the Catholic Church, living on earth in order to fulfill the prophecy of the Book of Revelation. For this reason, she knew that she had to follow the authority of Bossuet and other Church leaders, and nowhere does Mme Guyon suggest that the seventeenth-century Church be forsaken. This is why in late 1695 she did, by her own admission, sign the articles of Issy and attempted to hide herself from the world. But the overarching goal of her life, to carry out the vision of herself as the woman of the apocalypse, prompted her to abandon this former commitment. Additionally, it was necessary for persecution to continue in order to achieve this destiny, and defying Bossuet can be seen as a purposeful attempt to maintain, if not accelerate, condemnation. The reaction of her three antagonists to this behavior is, then, understandable on a new level beyond the issue of gender. Certainly it would be foolhardy to suggest that Mme Guyon's sex played no role whatsoever in the Quietist controversy; much recent work on the fundamental misogyny of the Catholic Church as a whole would prevent this statement from being true. ${ }^{308}$ Yet, it is also equally impossible to claim that the entire incident is based simply 
on misogyny and the desire of the priests involved to maintain male dominance. If this were true, Mme Guyon would never have gotten as far as the Council of Issy; Bossuet would have condemned her works as heretical immediately upon reading them because she was a woman. This assertion of misogyny also does not take into consideration that Fénelon was a well-educated Catholic priest, and was her greatest supporter. If the Church condemned Mme Guyon for her beliefs only because she was female, then why were La Combe and Fénelon similarly disgraced? Many would answer, "because they were men defending this woman," but why would two men, as a members of the same hierarchy as Mme Guyon's persecutors, ever think to protect her? Would they, especially Fénelon, not have the same negative, fearful impression of women as their colleagues? Bossuet states in the concluding chapter of Relation sur le quiétisme that Fénelon's writings presented the Guyonist prayer better that she herself had written it: "it is necessary to say that he explained better that which was unexplainable in [her] texts. ${ }^{\prime 309}$ Such a statement, along with the hardy distaste for her personality and her works as evident in chapter two of this thesis, allows that Bossuet was perhaps interested more in what she (and her supporters) were saying than in her gender.

While the bishop of Meaux has been characterized as dedicated to eradicating heresy at any cost, this thesis has suggested that theological issues

\footnotetext{
${ }^{308}$ For contemporary studies on anti-female attitudes inherent in Catholicism, see Alcuin Blamires, ed., Woman Defamed and Woman Defended: An Anthology of Medieval Texts (Oxford: Clarendon Press, 1992); Elaine Pagels, Adam, Eve, and the Serpent (New York: Vintage Books, 1989).
} 
were not the only problem he considered as a member of the Council of Issy. His actions in the Quietist Controversy, which I suggest be changed to the Guyonist Controversy, reveal that Bossuet had concerns about Mme Guyon's manner and personality which he struggled to regulate. Instead of overreacting and proclaiming her a heretic, Bossuet gave careful thought and consideration to the matter, and in the end decided that the only way to justify a declaration of heresy was to disguise his dislike and concern with the title of theological error. Despite his great eloquence and talent for writing, Bossuet was not able to completely irradiate the intentions behind his decision to condemn Mme Guyon. As to the reasons behind his concern for Mme Guyon's teachings, it is purely speculative to suggest that a living woman of the apocalypse could pose a real problem for authorities in the church and state. What Mme Guyon represented by claiming to be this woman was that the end of the world was near, and that her word was the word of God. Bossuet, normally portrayed as thoughtful and nonreactionary, clearly must have discarded these personality traits in order to pursue Mme Guyon's outrageous claims at any cost. It is for this reason that critics have concluded that Mme Guyon ruined his career, although to her credit, Bossuet was ultimately responsible for his reaction to her writings and her teachings.

As I have intimated in this final chapter, the life and writings of Mme Guyon demand to be examined, and reexamined, for evidence of her clever and

309 Jacques-Bénigne Bossuet, "Relation sur le Quiétisme," in Oeuvres (n.p.: Bibliothèque de La Pléiade, 1960), 1173. 
purposeful manipulations of words and people to convey her living sanctity. No matter the occasion, Mme Guyon knew the direction she was headed as she attempted to convince others - and herself - that she was the highest saint, the true bride of Christ as represented by the travailing woman of the Book of Revelation. By the time she was released from the Bastille in March of 1703, it seems that Mme Guyon was aware that perhaps her vision was erroneous. Her religious activity declined, and she retired to her son's estate in Blois. In 1705, she told everyone that she was never going to write another essay or treatise, and indeed kept her word. This star of the religious scene in France in the $1680^{\prime}$ s and $1690^{\prime}$ s, who had been so vocal and so charismatic, spent her final years in mysterious silence. Although she met regularly with Protestant leaders from other countries, most notably Paul Poiret, her fervor and conviction was noticeably gone, as the duc de Saint Simon tells us in his memoirs. ${ }^{310}$ With the death of La Combe, the duc de Chevreuse, the duc de Beauvillier, and finally with Fénelon in 1712, the "little flock" passed out of existence. Something has to be said, however, for Mme Guyon herself. Following her death, this condemned heretic received a generous grave in the Church of the Cordeliers in Blois. After decades of persecution, discomfiture, and condemnation, the Catholic Church still welcomed her as one of its own.

\footnotetext{
${ }^{310}$ Louis de Rouvroy, duc de Saint-Simon, Mèmoires, vol. 5 (Paris: Bibliothèque de La Pléiade, 1948), 656.
} 


\section{BIBLIOGRAPHY}

\section{Primary Sources}

The Writings of Mme Guyon

Guyon, Jeanne Marie Bouviers de la Mothe. La Vie de Mme. J. M. B. de la Mothe Guion, Ecrite par elle-meme. Paris: Les Libraries Associes, 1791.

---. The Song of the Bride. trans. Gene Edwards. Sergant, GA: The Seedsowers, 1990.

---. Les Justifications de Madame J.M.B. de la Mothe Guion. Cologne: Chez Jean de la Pierre, 1720.

---. Le Cantique de Cantiques de Saloman. Lyon: Chez Antoine Braisson, 1688.

---. A Short and Easy Method of Prayer. Baltimore: B.W. Sower, 1812.

--. A Guide to True Peace or a Method of Attaining to Inward and Spiritual Prayer. New York: Samual Wood and Sons, 1816.

---. Poesies et cantiques spiritules. Paris: Libraries Associes, 1790.

---. Madame Guyon et Fénelon, la correspondence secrete. Paris: Dervy-Livres, 1982.

---. Poems. trans. William Cowper. Philidelphia: Kimbar, Conrad, and Co., 1804.

---. Union with God. trans. Gene Edwards. USA: Christian Press, 1981.

-.-. Experiencing God through Prayer. ed. Donna C. Arthur. Springdale, PA: Whitaker House, 1984.

---. Madame Guyon: An Autobiography. trans. Gene Edwards. Chicago, IL: Moody Press, 1970.

---. Final Steps in Christian Maturity. trans. George McCall. Auburn, Maine: Christian Books Publishing House, 1985. 
---. Spiritual Torrents. trans. Gene Edwards. Augusta, Maine: Christian Books, 1984.

---. Experiencing the Depths of Jesus Christ. trans. Gene Edwards. Auburn, Maine: Christian Books Publishing House, 1975.

---. Christ Our Revelation. trans. Gene Edwards. Sargent, GA: Seed Sowers Press, 1985.

\section{Other Primary Sources}

Angela of Foligno. The Complete Works of Angela of Foligno. trans. Paul LaChance. New York: Paulist Press, 1993.

--.. Le livre de la Bienheureuse Soeur Angèle de Foligno. ed. and trans. Paul Doncoeur. Paris: Librairie de I'art catholique, 1926.

Arouet, François (Voltaire). The Age of Louis XIV. New York: Everyman's Library, 1961.

Bossuet, Jacques-Benigne. Relation sur le Quietisme. London: J. Harris and A. Bell, 1698.

---. "Relation sur le Quiétisme," in Oeuvres. n.p.: Bibliothèque de La Pléiade, 1960.

Burnet, Gilbert. Three Letters Concerning the Present State of Italy. London: s.n., 1688.

Catherine of Siena. The Dialogue of the Seraphic Virgin Catherine of Siena. trans. Algar Thorold. Westminster, MD: Christian Classics, 1973.

Chantal, Jeanne-Françoise Fremyot de. Lettre inedits de la Sainte mere JeanneFrancois Fremyot. Paris: ). Lecoffre, 1860.

---. St. François de Sales: a testimony. trans. Elizabeth Stopp. Maryland: Institute of Salesian Studies, 1967.

Fénelon, François de Salignac de La Mothe. Explication des maximes des saints sur la vie interieure. London: H. Rhodes, 1698. 
---. Fénelon and Madame Guyon: Documents Nouveaux et inedits. Paris: Hachette, 1907.

---. Christian Perfection. trans. Mildred W. Stillman. London: Harper \& Brothers Publishers, 1947.

---. Spiritual Letters. trans. Gene Edwards. Augusta, Maine: Christian Books Publishing House, 1982.

Hadewicjh of Brabant. Hadewicjh: the Complete Works. trans. Mother Columbia Hart. New York: Paulist Press, 1980.

Innocent La Maisson, La vie de Messire Jean d'Arenthon d'Alex, éveque de Genève. Lyon: Chez François Comba, 1699.

John of the Cross. The Dark Night of the Soul. trans. Kurt F. Reinhardt. New York: F. Ungar Publishing Co., 1957.

---. Living Flame of Love. trans. E. Allison Peers. Garden City, New York: Image Books, 1962.

Molinos, Miguel de. Cuida Spirituale. London: s.n., 1688.

-.-. The Spiritual Guide which Disintangles the Soul. London: Methuen and Co., 1927.

Nicole, Pierre. Refutation des principlaes erruers des Queitists contenues dans les livres censurez. Paris: G. Desprez, 1695.

Saint-Simon, Louis de Rouvroy, duc de. Mèmoires. vol. 1 to 7. Paris: Bibliothèque de La Pléiade, 1948.

Sales, François de. Introduction a la vie devote. Paris: Societe d'Edition "Les Belles Letters," 1961.

---. Treatise on the Love of Cod. trans. Miles Car. Ilkley: Scolar Press, 1975.

Teresa of Avila. The Autobiography of St. Teresa of Avila. trans. E. Allison Peers. Garden City, NY: Image Books, 1960. 


\section{$\underline{\text { Secondary Sources }}$}

Aegerter, Emmanuel. Madame Guyon, une adventuriere mystique. Corbeil: Hachette, 1941.

Bedoyere, Michael de la. The Archbishop and the Lady: The Story of Fénelon and Madame Guyon. New York: Pantheon Books Inc., 1956.

---. François de Sales. New York: Harper, 1960.

Beer, Francis. Women and Mystical Experience in the Middle Ages. Rochester, NY: Boydell Press, 1992.

Bigelow, John. Molinos the Quietist. New York: Scribner Press, 1882.

Bishop, Donald, ed. Mysticism and the Mystical Experience: East and West. Toronto: Associated University Presses, 1995.

Blamires, Alcuin, ed. Woman Defamed and Woman Defended: An Anthology of Medieval Texts. Oxford: Clarendon Press, 1992.

Bremond, Henri. Histoire litteraire du sentiment religieux en France depuis la fin des guerres de religion jusqu'a nos jours. vol. 2-6, vol. 11. Paris: Bloud et Gay, 1916-1933.

Burrows, Elizabeth MacDonald. Odyssey of the Apocalypse. Seattle: Archives International, 1994.

Butler, Alban. Lives of the Saints. ed. Michael Walsh. San Francisco: Harper Collins, 1991.

Bynum, Caroline. Holy Feast and Holy Fast: The Religious Significance of Food to Medieval Women. Berkeley: University of California Press, 1987.

Calvet, Jean. La litterature religieuse de Francois de Sales a Fénelon. Paris: Del Duca, 1956.

Cazelles, Brigitte. The Lady as Saint. Philadelphia: University of Pennsylvania Press, 1991.

Cheever, Henry T. Corresondencies of Faith and Views of Madame Guyon. London: Elliot Stock, 1887. 
Cheney, Sheldon. Men Who Have Walked With God. New York: A. Knopf, 1945.

Child, Lydia. The Biographies of Lady Russell and Madame Guyon. Boston: Carter, Hendee, and Co., 1832.

Clark, John. A Map of Mental States. London: Routledge and Kegan Paul, 1983.

Costlet, Dorothy Gawne. Madame Jeanne Guyon: Child of Another World. Washington, PA: Chistian Literature Crusade, 1984.

Delacroix, Henri J. Les grands mystiques chretiens. Paris: F. Alcan, 1938.

Delany, Selden. Married Saints. Westminster, MD: The Newman Press, 1950.

Duclaux, Mme. The French Ideal: Pascal, Fénelon, and Other Essays. trans. A. Mary F. Robinson. London: Chapman and Hall, 1911.

Eddy, Mary Baker. The Revelation of St. John: An Open Book. Dorchester, MA: The Open Book, 1922.

Egan, Harvey D. Christian Mysticism: The Future of a Tradition. New York: Puebloe Pub. Co., 1984.

Fiorenza, Elisabeth Schussler. Revelation: Vison of a Just World. Minneapolis: Fortress Press, 1991.

---. Invitation to the Book of Revelation. Garden City, NY: Image Books, 1981.

Frost, R.N. Authority in the Bossuet-Fénelon Debate. Evengelical Theological Society Papers, 1992.

Garvey, John. Meditations on Saints. Chicago: Thomas More Press, 1975.

Gondal, Marie-Louise. Madame Cuyon: Un Nouveau Visage. Paris: Beauchesne, 1989.

Goodier, Alban. An introduction to the Study of Ascetical and Mystical Theology. Milwaukee: The Bruce Pub. Co., 1957.

Goubert, Pierre. Louis XIV and Twenty Million Frenchmen. trans. Anne Carter. New York: Vintage Books, 1970. 
Guerrier, Louis. Madame Guyon, sa vie: sa doctrine et son influence, d'apres les ecrits originaux et des documents inedits. Paris: Didier et cie, 1881.

Happold, F.C. Mysticism: A Study and An Anthology. Baltimore, MD: Penguin Books, 1967.

Harrington, Wilfred J. Revelation. Collegeville, MN: The Liturgical Press, 1993.

Hearnshaw, F. J. C. The Social and Political Ideas of Some Great French Thinkers of the Age of Reason. New York: Barnes and Noble Inc., 1931.

Hubbard, Elbert. Little Journies to the Homes of the Great. Vol. 13. Cleveland, $\mathrm{OH}$ : The World Publishing Co., 1928.

Kelty, Mary Ann. Religion of the Heart: Exemplified in Memorials of Madame Guyon, Fénelon and other Spiritual Persons. London: Henry G. Bohn, 1844.

Kramer, Herman B. The Book of Destiny. Rockford, IL: Tan Books and Publishers, Inc., 1955.

Krodel, Gerhard. Revelation. Minneapolis: Augsburg Pub. House, 1989.

Ladd, George. A Commentary on the Revelation of John. Grand Rapids, MI: William B. Eerdmans Pub. Co., 1987.

Laude, Patrick, Approches du quietism: deux etudes. Paris: Papers on French Seventeenth-Century Literature, 1991.

Lewis, W.H. The Splendid Century: Life in the France of Louis XIV. Garden City, NY: Doubleday Anchor Books, 1957.

Libouroux, Charles. Controverse entre Boussuet et Fénelon au sujet de Quietisme de Mme. Guyon. Paris: Rochefort, 1876.

Little, Katharine Day. Francois de Fénelon: Study of a Personality. New York: Harper and Brothers Publishers, 1951.

Mallet-Joris, Francoise. Jeanne Guyon. Paris: Flammarion, 1978.

Martindale, C.C. The Queen's Daughters: A Study of Women Saints. New York: Sheed and Ward, 1951. 
-.-. What are Saints?: Fifteen Chapters in Sanctity. Freeport, NY: Books for Libraries Press, Inc., 1968.

McGee, J. Vernon. Reveling Through Revelation, part II. Pasadena: Thru the Bible Books, n.d.

McGinley, Phyllis. Saint-Watching. New York: Viking Press, 1969.

McGinn, Bernard. The Foundations of Mysticism. vol. 1. New York: Crossroad, 1991.

---. The Growth of Mysticism. vol. 2. New York: Crossroad, 1991.

Olson, Bessie G. Madame Guyon: A Great Heroine. Wheaton, IL: Van Kampen Press, 1946.

Pagels, Elaine. Adam, Eve, and the Serpent. New York: Vintage Books, 1989.

Penn-Lewis, Jessie. Life out of Death: A Brief Summary of Mme. Guyon's "Spiritual Torrents" and other papers on the Spiritual Life. England: Overomer Literature Trust, 1970.

Petroff, Elizabeth. Body and Soul: Essays on Medieval Women and Mysticism. New York: Oxford University Press, 1994.

---. "Medieval Women Visionaries: Seven Stages to Power," Frontiers 3(1978): 34-45.

Pike, Nelson. Mystic Union: An Essay on the Phenomenology of Mysticism. Ithaca, New York: Cornell University Press, 1992.

Raiton, George S. Madame Jeanne de la Mothe Guyon. London: Salvation Army Headquarters, 1881.

Rébelliau, Alfred. Bossuet. Paris: Librarie Hachette, 1912.

Reynolds, E.E. Bossuet. Garden City, NY: Doubleday and Co., 1963.

Ribadeau Dumas, François. Fénelon et les saites folies de Madame Guyon. Geneve: Ed. du Mont-Blanc, 1968.

Sanders, E.K. Fénelon: His Friends and His Enemies. London: Longmans, Green, and Co., 1901. 
Schnapper, Edith, The Inward Odyssey: The Concept of the Way in the Great Religions of the World. Boston: Allen and Unwin, 1980.

Seilliere, Ernest Antoine Aime Leon, Baron. Les Educateurs mystiques de l'ame moderne. Madame Guyon et Fénelon, presecurseurs de Rousseau. Paris: F. Alcan, 1918.

Shewen, W. A Guide to True Peace. Philidelphia: Henry Longstreth, 1877.

Sonnino, Paul, ed. The Reign of Louis XIV. New Jersey: Humanities Press International, Inc., 1990.

Suzuki, Daisetz. Mysticism: Christian and Buddhist. New York: Harper, 1957.

Szarmach, Paul, ed. An Introduction to the Medieval Mystics of Europe. Albany: SUNY Press, 1984.

Thompson, Phyllis. Madame Guyon, Martyr of the Holy Spirit. London: Hodder and Stoughton, 1986.

Thorold, Algar. An Essay in Aid of the Better Appreciation of Catholic Mysticism. London: Kegan, Paul, Trench, Trubner, 1900.

Underhill, Evelyn. The Essentials of Mysticism. New York: E.P. Dutton and Company, Inc., 1960.

---. Mysticism. New York: E.P. Dutton, 1911.

---. The Mystics of the Church. New York: Schoken Books, 1964.

Upham, Thomas C. Life and Religious Opinions and Experiences of Madame Guyon. vols. 1 \& 2. New York: Harper and Brothers, 1858.

Vinck, Jose de. Revelations of Women Mystics. New York: Alba House, 1985.

Ward, Patricia. "Madame Guyon in America: An Annotated Bibliography." in Bulletin of Bibliography 52 (June 1995): $107-115$.

Weinstein, Donald, and Rudolph Bell. Saints and Society: The Two Worlds of Western Christendom, 1000-1700. Chicago: University of Chicago Press, 1982. 
Whitehead, Elizabeth. Saints for the Married. Liverpool: The Mercier Press Limited, 1949.

Wiethaus, Ulrike, ed. Maps of Flesh and Light: The Religious Experiences of Medieval Women Mystics. Syracuse: Syracuse University Press, 1993.

---. "Madame Guyon and the Democratization of Spirituality." in Papers on Seventeenth Century French Literature 23 (1996): 501 - 512.

Williams, Caroline. Saints: Their Cults and Their Origins. New York: St. Martin's Press, 1980. 


\section{Appendix A:}

\section{Chapter Twelve of the Book of Revelation}

Quoted directly from the Westminster version of the Sacred Scriptures. (This version of the Book of Revelation seems to be the favorite of contemporary commentators.) 


\section{The Woman and the Dragon.}

And a great sign was seen in heaven: a ${ }^{1}$ woman clothed with the sun, the moon under her feet, and upon her head a crown of twelve stars.

She is with child, and crieth out in her ${ }^{2}$ travail, and is in anguish of delivery. And ${ }^{3}$ another sign was seen in heaven - behold, a great red dragon, having seven heads and ten horns, and upon his heads seven diadems; his tail draweth after it the third part of ${ }^{4}$ the stars in heaven, and it cast them to the earth. And the dragon stood before the woman who was about to bring forth, and in order that when she should bring forth he might devour her son.

And she brought forth a male child, who is ${ }^{5}$ destined to rule all the nations with a rod of iron; and her child was caught up to God and to his throne.

The woman herself fled into the wilderness, ${ }^{6}$ where she hath a place prepared by God wherein she is to be nourished during a thousand two hundred and sixty days.

And a battle took place in heaven, Michae $^{7}$ and his angels battling with the dragon. And the dragon and his angels battled, and they prevailed not, nor was their place ${ }^{8}$ found any more in heaven.

And he was cast down, the great dragon, the ${ }^{9}$ ancient serpent, who is called the Devil and Satan, he who seduceth the whole world - he was cast down to earth, and his angels were cast down with him.

And I heard a loud voice in heaven, saying: ${ }^{10}$ Now is come the salvation and the might and the kingdom of our God, and the power of his Christ; because the accuser of our brethren hath been cast down, he who accuseth them day and night before our God.

And thy have conquered him through the blood of the Lamb, and through the word of their " witness, and they loved not their life in face of death.

Wherefore be glad, O ye heavens, and ye that dwell therein! Woe to the earth and to the ${ }^{12}$ sea, because the devil hath gone down to you in great fury, knowing that he hath but a little time!'

And when the dragon saw that he was cast ${ }^{13}$ down to the earth, he pursued the woman who had brought forth the male child. 
And there were given to the woman the two ${ }^{14}$ wings of the great eagle, in order that she might fly into the wilderness, to the place where she is to be nourished a time and times and half a time away from the serpent.

Then the serpent cast out of his mouth, after ${ }^{15}$ the woman, water like a river, that she might be swept away in its flood.

But the earth came to the help of the woman; ${ }^{16}$ the earth opened its mouth, and swallowed the river which the dragon had cast out of his mouth.

And the dragon was wroth at the woman, and departed to make war with the rest of her seed, ${ }^{17}$ with them that keep the commandments of God and bear witness to Jesus.

And he stood upon the sand of the sea. 


\section{Appendix B:}

\section{The Covenant of Consecration of Mme Guyon 22 July 1672}

Quoted from Thomas Upham, Life and Religious Opinions and Experiences of Madame Cuyon. vols. 1 (New York: Harper and Brothers, 1858), 140. He reportedly drew this agreement from an unpublished letter written by Mme Guyon. This covenant is not included in the Vie of Mme Guyon. 
I henceforth take Jesus Christ to be mine. I promise to receive him as a husband to me. And I give myself to him, unworthy though I am, to be his spouse. I ask of him, in this marriage of spirit with spirit, that I may be of some mind with him, -- meek, pure, nothing in myself, and united in God's will. And, pledged as I am to be his, I accept, as a part of my marriage portion, the temptations and sorrows, the crosses and the contempt which fell to him.

Jeanne-Marie Bouvier de la Mothe Guyon 